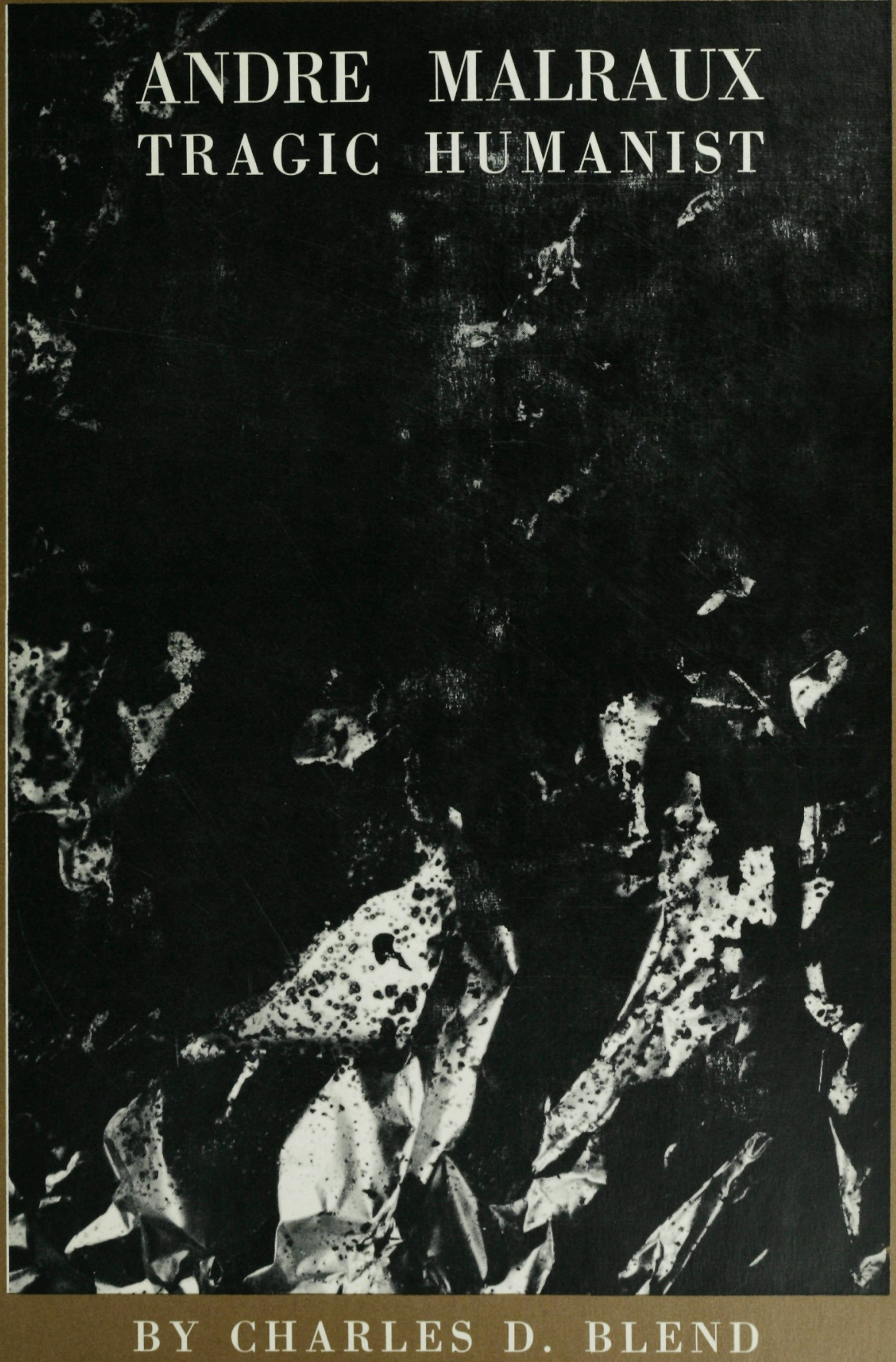




\section{ANDRE MALRAUX}

\section{TRAGIC HUMANIST}

\section{BY CHARLES D. BLEND}

The dominant question arising from the unparalleled inhumanity of the mid-twentieth century, André Malraux has suggested, is "Is man dead?" Yet, for him, to pose the question is to answer it, for man proves his greatness, not by affirming it, but by questioning. It is by a mise en question of the universe that man rises above it.

This interpretation, long central to Malraux's thinking, brings with it a number of difficulties. Previous concepts of man have produced an image, an ideal, toward which man could orient himself, and have presupposed a culture that had a form and, often, a humanistic attitude that alloted man a role in the scheme of things. With a vision of man based on questioning rather than affirmation, it becomes impossible to preconceive 




\section{ANDRE MALRAUX \\ tragic humanist}


Je ne sais d'assurés, dans le chaos du sort, Que deux points seulement: la souffrance et la mort. Tous les hommes y vont avec toutes les villes, Mais les cendres, $j$ e crois, ne sont jamais steriles.

-Alfred de Vigny, Paris 


\section{ANDRE MALRAUX tragic humanist}

by Charles D. Blend Ohio State University Press 
Copyright (C) 1963 by the Ohio State University Press

All Rights Reserved

Library of Congress Catalogue Card Number: 62-19865 
To the memory of my brother, the late George $W$. Blend, Captain, Cavalry, AUS, with whom I knew "la fraternité virile," and who showed by example that life can be lived with dignity while one is fully aware of approaching death. 'L'irreductible accusation du monde qu'est un mourant qu'on aime." 



\section{AGKNOWLEDGMENTS}

The DEBTS I owe to others for help in the preparation of this study are numerous and important. I am very grateful to André Malraux for the encouragement he gave me after reading this work in its original form and for the additional valuable information he furnished, not only in conversation and letters, but in the hard-to-find texts he so kindly supplied. He was also most generous in granting me permission to quote extensively from his writings.

A very special gratitude is due to Don L. Demorest of the Ohio State University, whose course on the contemporary French novel first made me aware of André Malraux, and whose enlightened understanding, encouragement, and suggestions aided me at every stage of the preparation and execution of my work.

I wish also to thank the following American and British publishers, holdcrs of the copyrights to the excellent English translations of Malraux's works, for their permission to excerpt passages from their editions, and for their generous authorization to substitute my own somewhat uneven translations for the official ones: Doubleday and Company, Inc.; Random House, Inc.; John Lehmann Ltd.; Martin Secker and Warburg Ltd.; and Methuen and Company Ltd. These same courtesies were also extended to me in connection with the extracts from Saturn: An Essay on Goya, by André Malraux, published by Phaidon Press Ltd., London, and distributed by the New York Graphic Society, Greenwich, Connecticut.

The editors of Yale French Studies were kind enough to permit me to re-use in the second chapter of this book much of the same material that appeared in my article "The Rewards of Tragedy." 
$\begin{array}{llllllllllllllll}\text { viii } & \text { A } & \text { C } & \text { K } & \text { N } & \text { O } & \text { W } & \text { L } & \text { E } & \text { D } & \text { G } & \text { M } & \text { E } & \text { N } & \text { T } & \text { S }\end{array}$

The American Philosophical Society has my sincere appreciation for the grant of travel funds that made it possible for me to do necessary research in France.

My colleagues, Kenneth R. Scholberg of the Ohio State University, James Doolittle of the University of Cincinnati, Juan B. Avalle-Arce of Smith College, and Bruce W. Wardropper of Duke University are all offered my gratitude for reading and listening to my text and offering valuable suggestions for its improvement.

Finally, I wish to thank my wife, Rhoda C. Blend, for the long hours spent typing and proofreading.

Charles D. Blend 
GONTENTS

Introduction

I. An Active Humanist

9

II. Humanism and Tragic Poetry

III. Ethos, or the Struggle with the Demon

IV. Artistic Creation, or the Struggle with the Gods

V. The Fundamental, or the Struggle with the Earth

VI. The Problem of the Absolute

VII. The Individual and the Culture

Epilogue on the Tragedy of Political Action

Appendix

Address Given by His Excellency André Malraux, Minister of Cultural Affairs of the French Republic, on the Occasion of the Fiftieth Anniversary of the French Instilute of New York, on Tuesday, May 15, 1962 

INTRODUGTION 

Wiтн General de Gaulle's return to power in the spring of 1958, history brought André Malraux back before the public in the role of a man deeply involved in the great events of our time. From the relative seclusion in which Malraux had been preparing his books on art, he emerged to plunge full force into the French political crisis. This was the latest, but probably not the last, of a series of moves from action to art and vice versa, by a man who has, as have few others, associated himself closely and vitally with both. It would be difficult to find a more dramatic illustration of this dual activity than that encompassed in the period from the end of 1957 through the first months of 1958. When the first volume of The Metamorphosis of the Gods (La Métamorphose des Dieux) ${ }^{1}$ appeared in the closing weeks of 1957, interest in it was so great that the first edition, in spite of its high price, was bought up as soon as it reached the bookstores. With a few notable exceptions, French critics were extreme in their praise of the work, many seeing in it, even though it was incomplete, one of the greatest works of all time on art. According to one of Malraux's closest friends, he intended it to be a climax in his literary production. Nevertheless, when the events that led to De Gaulle's reappearance as prime minister took place, Malraux dropped all work on the second volume of his book to become: first, Minister of Information; then, Minister Delegate; and finally,

${ }^{1}$ I have used the standard American titles for the works of André Malraux that have been translated into English. French titles have been retained for the untranslated works. 


\section{ANDRE MALRAUX: TRAGIC HUMANIST}

Minister of Cultural Affairs in the new government. This last probably gave him his best opportunity to date to synthesize art and action.

One of the best indications of the extent and depth of Malraux's impact is the quantity of criticism and controversy he has aroused. Much of this is written from a religious or political parti-pris and makes little effort to grasp the genuine significance of Malraux's work, being more interested in attacking or refuting his major premises. In part, the quantity and intensity of this criticism stems from the fact that everything Malraux has written implies a specific attitude toward life, an attitude that is often seriously in conflict with the tenets of major political, religious, and artistic positions extant in the contemporary world. It is also, in part, because he puts it forward with such force and persuasiveness that it hits with enormous impact, although he is always careful to state that his attitude toward the world is just one among many that are possible. The result has been that the opposition to some aspects of his works has been distinguished, not only by its volume and intensity, but also by the stature of those who have voiced it. No less a revolutionary figure than Leon Trotsky felt called upon to bring Malraux to task for what he, Trotsky, felt were ideological shortcomings in The Conquerors (Les Conquérants). Roger Garaudy, the keeper of the index for the French Communist Party, has gone to considerable lengths to prove that Malraux is not really worth reading after all, that he is only "the finest flower of bourgeois decadence." The Honor of Being a Man, by Edward Gannon of the Society of Jesus, is essentially a riposte at Malraux's agnosticism. All these, however, are dwarfed by Georges Duthuit's Le Musée inimaginable, a three-volume blast at Malraux's art theories. To justify this much effort to refute Malraux, these writers must have felt that he is not only wrong but decidedly influential. To cite Sainte Beuve: "Nothing serves better to mark the extent of a talent, to circumscribe its sphere and its domain, than to know the precise points at which the revolt against him begins." 
Even when critics who write from strongly held viewpoints do attempt to treat Malraux's writings impartially, they often fail to grasp its unity and most profound meaning because, to paraphrase a remark made by Malraux in D'une jeunesse européenne, they see it through the filter of a world vision that is not that of the work itself. The fundamental source of the major actions in Malraux's life and in all his works from The Temptation of the West (La Tentation de l'Occident) to the present is to be found in his metaphysical position, the analysis of which is one of the major objectives of this book. Any reader or critic is, of course, free to accept or reject Malraux's attitude as he chooses, but any endeavor to interpret his work that substitutes a Christian, Marxist, or any other vision for Malraux's own can be at best only partially successful. To be fully apprehended, Malraux's life and writings must be considered on their own terms.

The negative reaction to Malraux is opposed by a far greater body of criticism whose response is largely appreciative. With some of these the present study is, inevitably, to some degree on common ground. Pierre de Boisdeffre and André Rousseaux have written chapters on Malraux's humanism but without associating it with tragedy. W. M. Frohock's perceptive study, André Malraux and the Tragic Imagination, deals effectively with many aspects of the tragic in Malraux's works but nowhere mentions humanism nor does it go into the problem of what Malraux himself means by tragedy. This last is the real key to the unity of his life and work. Both Malraux and the heroes he has created have been involved in situations with tragic implications, but it is not necessary for them to seek out such situations in order to attain the domain of tragedy. From the start they are immersed in a tragic totality of which the political and other events that crush them are only the physical manifestations.

Viewed from this position, and particularly if one is not aware of the full resonance that the word tragedy has for Malraux, his world may appear to be entirely negative, a world justifying the epithet "pessimistic" with the 
overtones of hopelessness that it is given in much American writing; "realistic" would perhaps be a better term. Even more in line with Malraux's own vocabulary would be "virile" as Nietzsche employs it with respect to the pre-Socratic Greek philosophers: the ability to face terrible facts squarely. The facts of the twentieth century would seem to make Malraux's grim vision accurate.

For Malraux, though, the result is neither despair nor surrender but a positive attitude toward life. In order to represent the path by which, for Malraux, the human will can convert tragic reality into an attitude of both dignity and fertility, it is necessary to couple the terms "tragic" and "humanism." Here I have let Malraux be my guide: the phrase "tragic humanism" is his.

Treatment of Malraux's writings is complicated by his style, which is often characterized by lyricism, ellipsis, incomplete sentences, and a prophetic tone. Professor Frohock, among others, has pointed out that Malraux is essentially a poet, an interpretation with which I am in full agreement. However, in analyzing Malraux's most important ideas, I have relied less upon the interpretation of his poetry than upon a comparison of texts and the relationship of these texts to Malraux's own life. Virtually all the important themes Malraux elaborates in his fictional works he treats elsewhere in non-fictional form, and much that appears difficult or ambiguous in his creative writing becomes clear when viewed in the light of his speeches and articles. This comparative method has forced me to forego use of the excellent translations made of Malraux's major works in favor of my own versions. While this may entail a loss of literary quality, understanding of Malraux often hinges upon certain key expressions that recur as leitmotivs throughout his work. The effect is often lost in translation, mainly because his works have had different translators.

Malraux is fond of stating that as soon as a modern writer becomes fully "involved," his complete works are implicit in everything he writes. How- 


\section{ANDRE MALRAUX: TRAGIC HUMANIST 7}

ever true this may or may not be generally, it applies to Malraux himself. The recurrence and development of major themes, in addition to serving as the basis of my elucidation of some of Malraux's more complex ideas, has determined the form of this book. After a general opening section on Malraux's career, I have chosen, rather than to devote a chapter to each book, to build each chapter around an important aspect of Malraux's humanism. This form makes it possible to show without undue repetition the consistent presence and development of Malraux's chief themes in all his major works and makes the fundamental unity of thought more evident. It is not as fashionable as it was ten years ago to speak of the about-face in Malraux's thinking, or to write, as did Emmanuel Mounier, of his impossible déchéance. Nevertheless, I feel that the degree to which Malraux's current positions have always been present in his works has not yet been properly demonstrated nor has the natural unity of his thought and actions been clearly shown. To use one of Malraux's own images, the essential seed has never been absent while the tree of his life and work was growing. Even the shifts from action to art and back again are really only shifts of emphasis among the preoccupations that have always motivated him. Behind the apparent changes lies Malraux's need, shared with his crcation Kyo, "to conquer without betraying himself."

Malraux's own work-all of which, whether the subject is revolution or art, is essentially ethical in nature-has determined the emphasis of this book: the ethical. As early as 1933, he wrote to Edmund Wilson of his need to represent, by means of the characters he created, "a certain order of ethical values." These same values have been the guiding principles of Malraux's extremely active life.

More than twelve years have passed since I first became interested in André Malraux. I say intentionally André Malraux and not André Malraux's works because, to a very high degree, the man and the work form a fused whole. Everything he has written has been the product, either directly or 
indirectly, of the rich experience of his life. This unity of life and work has always been one of the things about Malraux that most appealed to me. The problems with which he deals are eternal, but he has lived and written of them in such a way that his books form both a significant echo of one of the most crucial periods of human history and partake of the more durable quality of art. In general, I am not only stimulated but attracted by the way in which Malraux treats these problems, and the attraction has grown with each new phase in the evolution of his thought. In short, my position is a sympathetic one, controlled, I hope, by the requirements of critical objectivity. 


\section{I}

AN ACTIVE HUMANIST

Except for memoirs, what books are worth writing?

- "The Conquerors" 

On the sixth of November, 1946, André Malraux stood on the tribune of the main amphitheater in the Sorbonne. Before him sat people gathered from many of the countries that make up the United Nations. Around him spread a ravaged Europe where, to use his own words, the fires in the crematory ovens had hardly cooled. In many respects he also stood at a pivotal point in his career. At forty-six, there lay behind him, not only revolutionary and military activity in China, Indo-China, Spain, and France, archaeological expeditions to the Near and Far East, but also the novels that have made his name one of the foremost in contemporary literature. The great books on art were yet to appear. In the past was the long period of collaboration with the Communists and the causes of the extreme left. He was almost at the beginning of his political association with General de Gaulle.

The world, too, appeared to be at some crucial point. The occasion was a UNESCO sponsored series of lectures on the general themes of education, science, and culture. Presided over by Stephen Spender, the series had as speakers men of international reputations in their respective fields. Considering the shattered state of the world at that historical moment with mankind's most sanguinary hot war just over and the recent Allies already confronting one another in a so-called cold war, many of Malraux's listeners were probably hoping for some suggestion as to a possible way out of the impasse into which humanity had worked itself. What the path might be no one could tell, but it was difficult to believe that anything could be worse than the period of imprisonment, torture, and death that had just 


\section{ANDRE MALRAUX: TRAGIC HUMANIST}

passed. What the first great war had left of the nineteenth-century dreamand Malraux himself said that with all its shortcomings the nineteenth had been one of the most humane of centuries-had been consumed in the fiery agony of which the crematory ovens are so apt a symbol. It followed naturally that many of the basic values and assumptions, the scientific and humanistic concepts that had guided the occidental world, should have had their validity called into question.

Malraux called his lecture "l'Homme et la culture artistique," not, he said, because art offered a panacea, but simply because it was his own particular field. He began by pointing out that in ages past man had had a definite idea of what he was and where he was going, a vision of his role in the universe. According to Malraux, the major victim of the Second World War, even more than Europe itself, had been the Western concept of man. The unparalleled inhumanity of the mid-twentieth century had made a shambles of the various visions of a steadily progressing humanity, be it under the guidance of science, reason, or religion. Pushing Nietzsche's "God is dead" one stage further, he suggested that the dominant question of the moment was "Is man dead?"

For Malraux to pose the question was equivalent to answering it in the negative, since, according to him, man really proves his greatness, not by affirming it, but by questioning and interrogation. It is by a mise en question of the universe that man rises above it, not by merely stating that he has a major role therein. This interpretation, long central to Malraux's thinking, brings with it a number of difficulties. Each of the former concepts of man had produced an image of man on which an individual could focus his vision, an ideal toward which to orient himself. By extension each presupposed a culture that had a form and, often, a humanistic attitude that allotted man a definite role in the scheme of things. With man, in Malraux's vision, based on questioning and interrogation rather than affirmation, it is impossible to preconceive an image of him. With such a perspec- 


\section{ANDRE MALRAUX: TRAGIC HUMANIST 13}

tive as Malraux's as a starting point, a form for human culture cannot be visualized and traditional humanism passes from the picture. The future of humanity would be completely unpredictable, but, as Malraux said, he preferred an unpredictable future to a false one, and, as he remarked ironically in another speech, it had not been foreseen that the "tomorrows that sing" would have prisoners' songs as their theme.

If man no longer had a preconceived image of himself, he still had something that, for Malraux at least, is even greater: consciousness or awareness. To replace the images, destroyed or invalidated, Malraux called for the will to grasp the greatest possible consciousness of what it is to be a man coupled with the will to absolutely free discovery. These, he said, had always really been the fundamental European values. Combining these values, Malraux suggested that the preformed cultures might be replaced with what he called a "culture des grands navigateurs," taking his idea from the great voyages of the age of discovery when many of the navigators set out without knowing what they would find. Culture seen thus becomes a human adventure, an adventure in freedom. Coming then to the heart of his talk, Malraux stated that even under such conditions humanism was still possible, but it must be made very clear that it would be a tragic humanism-humanism, because man could know his will and his starting point; tragic, because he could never know where he was going. Given the will to carry on this endless struggle with the unknown, man could arise once more from the ashes around him to lead an existence of dignity and fruitfulness.

This somber and heroic vision is the most complete and connected statement of his philosophy of life that Malraux has ever made. Coming as it does after a quarter century of deep involvement in the realms of political action, art, and archaeology, it can be said to represent the position of the mature Malraux. However, while it may be the culmination of his thinking, it contains nothing essentially new in his work, unless it is the crystalliza- 


\section{ANDRE MALRAUX: TRAGIC HUMANIST}

tion of his terminology into such phrases as a "culture of great navigators" and "tragic humanism." With these terms we are at the crux of the attitude toward existence that not only gives his life and art a unity that approaches total fusion but also qualifies it as tragic. It is obvious that any conclusions reached according to this view will necessarily be a posteriori, derived from the essential experience of being a man, of living life and testing its poss1bilities. Each new step will really be a question since the result will be unknown until attsined. The consciousness of what it is to be a human being, upon which Malraux puts so much emphasis, is nothing more or less than an awareness of the significance of each of the steps and of their sum total. Perhaps no aphorism of Malraux's is more famous than the reply, in Man's Hope (L'Espoir), to the question "What is the best thing that a man can do with his life?" "Transform into consciousness an experience as wide as possible." This idea is a persistent one with Malraux. Before Man's Hope, in Man's Fate (La Condition humaine), he had Gisors say of his son Kyo that he believed ideas were not to be thought but to be lived. In 1951, Malraux wrote of his friend Manès Sperber's Qu'une larme dans l'océan that it was "l'experience humaine devenue lucidité." Extended from the individual to mankind as a whole, this is the same as his tragic humanism. Malraux's books, including his views on art, are simply his consciousness of the significance of his own life experience transcribed as literature.

Kenneth Burke, in the short but very suggestive chapter on the dialectic of tragedy in his Grammar of Motives, finds that tragic movement is a progression from poiemata to pathemata to mathemata, or purpose to passion to perception. ${ }^{1}$ Using Oedipus as his example, he demonstrates how the

${ }^{1}$ W. M. Frohock in his book André Malraux and the Tragic Imagination and Bart M. P. Leefmans in his article "Malraux and Tragedy: The Structure of $L a$ Condition humaine" have used Burke's formula in dealing with Man's Fate. No one, to the best of my knowledge, has yet applied it to Malraux's work as a whole or seen its relationship to the aphorism from Man's Hope. 
tragic hero begins with a major purpose, undergoes one or more conflicts, and arrives at the perception of a truth. If one compares this formula to Malraux's experience becoming awareness, it is clear that the difference is only one of terminology; in essence they are the same. If Burke's theory can be granted validity, Malraux's life, art, and humanism must all be visualized as tragic and the last two as results of the first to which they are united in a remarkable synthesis: not just tragedy but tragic poetry. Such being the case, the next step is to consider the life and works that produced the tragic humanism.

Malraux himself is extremely reticent concerning the facts of his personal life. True to his formula, he feels that they have importance only as manifested in his work. In fact, when treating the first thirty years of his life in particular, we are forced to lean heavily on his works in order to deal with the man. There are long periods for which little or no precise data is available. Much of his activity took place in countries now under fascist or communist dictatorship, and Malraux's own memory is vague about specific dates. Malraux once remarked that anyone who says simply that Dostoevski spent several years in Siberia has said nothing not already said in the Russian prison records. The significance of the imprisonment lies in its effect on Dostoevski's novels. It is in this light that we attempt to approach the salient aspects of Malraux's own life.

Georges-André Malraux was born into a well-to-do Paris family on November 3, 1901. About his childhood years we have very little information and what we possess reveals nothing extraordinary. He went to school at the Lycée Condorcet and the Institut des Langues Orientales, this last probably stimulating the interest in archaeology and the Far East that was to play such an important role later in his life. By the time he was nineteen, he had published an article on the origins of Cubist poetry in the first issue of the literary magazine Connaissance, January, 1920. This beginning effort 


\section{ANDRE MALRAUX: TRAGIC HUMANIST}

was largely a historical summary and almost half is made up of quotations from various poets. The only things that one really notices in the article are the young writer's impatience with academics, his fascination with exotic polysyllabic words, and a somewhat heavy-handed irony not at all uncommon in young authors. There is, in fact, nothing in particular to distinguish it from dozens of other similar articles. Malraux continued to cut his literary teeth during 1920 with similar items in both Connaissance and Action, another of the French literary reviews of the period.

It was almost inevitable that a young man with André Malraux's restless imagination, moving about in the literary circles of postwar Paris, would be caught up in one of the avant-garde movements then flourishing so heartily. His exposure to the doctrines claiming freedom from all restraint for both imagination and language is reflected in his first fictional work Mobilités, in Action, March, 1920. As might be suspected from the title, it is an effort to convey the effect of complete visual and tactile mobility by means of words. The images are fantastic in the extreme and the writing is characterized by the same use of exotic vocabulary as in his non-fiction during the same period. Malraux produced several other similar short pieces, none of them having any particular distinction, but all demonstrating the unchecked imagination of the surrealist and other avant-garde groups. By contrast, however, while he was turning out this surrealistic bric-a-brac, Malraux also published a brief article on the genesis of Leautréamont's Chants de Maldoror in which he questioned whether the work of this nineteenth-century poet, an adopted forefather of the apostles of the fantastic, had any real literary value. Nineteen twenty-one saw the appearance of Lunes en Papier, the first of Malraux's fiction to appear as a separate work. Dedicated to the great French poet Max Jacob, of whose Art Poétique Malraux was soon to write a review, it is preceded by a line stating that it contains no symbols. Except for its greater length, there is little to set it apart from his previous efforts. Although frivolous items of this 
sort were to continue appearing over his name until 1928, it appears likely that they were written mainly during this earlier period.

During the first years of the 1920's, Malraux met and married Clara Goldschmitt, herself a person of not inconsiderable literary attainments. As Clara Malraux, she wrote several novels, two of which, Portrait de Griselédis and Par de plus longs chemins, are drawn from her life with André Malraux without duplicating his work in any way except that they derive from common experience. Her point of view is as feminine as his is masculine. Although Malraux and his wife had much in common, the marriage was an uneven one ending in divorce during the 1930's. They had one daughter, Florence, who has become one of her father's closest confidants.

Malraux continued to write articles and book reviews throughout 1922, and it was in this year that he appeared for the first time in La Nouvelle Revue Française, beginning an association with the Gallimard publishing house that has continucd to the present day. His critical judgment showed signs of both sharpening and deepening and it is evident that new elements are already present. In a brief article, "Aspects d'André Gide," he makes his first mention of Nietzsche, the man who was to become for him the greatest philosopher of the irrational. There are already definite Nietzschean overtones in Malraux's statement that "to struggle toward an illdefined goal, while taking into consideration one's own value and the possibility of increasing it, is the manifestation of all real intelligence and all real faith." The groundwork for his tragic humanism is already here. In this same review he touches upon the difference between a man's artistic personality and his ideological one, forecasting a problem that he will treat in a broader fashion in the Psychologie de l'art. Even this title is foreshadowed in the laudatory review he wrote of Max Jacob's Art Poétique. Taking exception to some of the poet's chapter titles, Malraux says that he would have preferred "Psychologie du sentiment artistique" or "Psychologie de la création artistique." 


\section{ANDRE MALRAUX: TRAGIC HUMANIST}

In the course of his studies at the Institut des Langues Orientales and as a result of his own reading, Malraux had acquired a solid knowledge of oriental art and archaeology. Having decided that he knew where to locate some lost Khmer temples on the so-called Royal Road in northern IndoChina, Malraux obtained an official archaeological assignment from the French government to look for them. At the age of twenty-three, he set out accompanied by his wife to locate the temples and bring back part of the sculpture. Although his relations with the colonial authorities appear to have been bad from the beginning, he completed the expedition and found the temples exactly where he expected them to be, no mean accomplishment for so young an archaeologist. He also contracted a recurrent fever that was still giving him trouble as late as 1950 .

Unfortunately, the archaeological triumph was to culminate in the humiliation of a public trial. Apparently under the impression that he could retain part of what he had discovered for himself, he had done just that. He was convicted of stealing government property and sentenced to three years in prison. It has never been definitely established whether or not he spent any time in prison, but there can be no doubt that the experience was a crucial one in the evolution of his philosophy, even if only as a catalyst for the crystallization of ideas already present. Prior to this event, his original writing had been of the frivolous variety. The Temptation of the West, which appeared in 1925 , is an entirely different matter. In it Malraux is already dealing with the problems and preoccupations that form the core of his thought to the present day. In the sense of the Goethian remark he is so fond of quoting, Malraux is now engagé; and, from The Temptation of the West forward, the essence of his thought will be present in every book he writes. "The human condition is also a prison," he will write in his essay on Goya. Malraux's wife returned to France to work for his release and his fellow writers rallied to his support, but his first head-on collision with human injustice had permanently colored his vision of the world. The human 


\section{ANDRE MALRAUX: TRAGIC HUMANIST 19}

condition remains for him a prison of which the man-made variety is only an extension. The trivial surrealistic writing will appear occasionally for three more years but its author regards it as "sans importance." Malraux had found the orientation that his major writing would follow.

The Temptation of the West consists of a series of letters between a young Chinese traveling in Europe and a young European moving about the Orient. Both are seeking in the foreign civilization answers to the problems with which their own has left them; neither is successful. While the book is severely critical of many Western attitudes, it would be wrong to interpret it, as has frequently been done, as a blanket condemnation of occidental civilization. The attacks by Ling, the Chinese correspondent, on the worship of force and order for their own sake reflect a point of view shared by Malraux. One has only to read his review of the ultra-nationalistic, ultra-conservative Henri Massis' Défense de l'Occident to discover passages that coincide with Ling's statements. Both men reach the conclusion that the result of European analytical thought has been to reveal the essential absurdity of human existence. However, Western thought did not create this absurdity, it only revealed it. The review of Massis' book tells in general terms what Malraux himself expected to find in the Orient. His journey to the East, he states emphatically, was not an attempt to lose himself but rather an effort to be rid of the academic mentality and the concept of the human personality held by such Europeans as Massis. This is a long way from being a rejection en bloc of European civilization.

The only important Malraux theme missing from The Temptation is politics. It was soon to make its appearance in both his life and his writing. The steps toward political action are outlined succinctly in a letter from Malraux to Edmund Wilson: "I then abandoned archaeology, organized the Jeune-Annam movement, became a commissar for the Kuomintangfirst in Indo-China, then at Canton." While in Saigon, he also organized and published a newspaper, l'Indochine enchaineée, the title of which is a 
good indication of its editors' political attitude vis-à-vis the colonial administration that had given Malraux so much trouble following his archaeological expedition. The authorities made considerable difficulty for the little newspaper, including the confiscation of part of the type. The numbers following the seizure show some rather odd typographical combinations. In his preface to Andrée Viollis' Indo-Chine S.O.S., Malraux recalls this incident and the efforts to overcome the consequent difficulties with fondness and, almost, with nostalgia. Throughout its short but lively existence, the paper carried on a continuous and violent attack on the abuses of the French colonial administration. The more conservative Saigon newspapers counterattacked strongly, making much of Malraux's trial in the affair of the Khmer sculptures. This, however, caused no letup in the paper's criticism of colonial policy. One note that might have been expected, considering the more intense political activity on which Malraux was about to embark, is absent. Critical of the government though they may be, none of the articles speak either about communism or the overthrow of the existing order. L'Indochine enchaînée lasted less than a year, but Malraux was to continue his struggle for the Annamite cause long after his paper had passed from the scene. As late as 1933, he wrote an article in the newspaper Marianne much like those he had written at Saigon.

Malraux's movements during the mid- and late 1920's around an Orient seething with revolution and violence are clouded in obscurity, but knowledge of his exact whereabouts at a specific time is of little or no importance. While his articles in l'Indochine enchaînée may say nothing in favor of violent action, the Kuomintang, with which his letter to Edmund Wilson associates him, was employing precisely that in order to oust the Chinese government then in power; and the big Canton strike, the setting for Malraux's first novel, had political rather than immediate economic gains as its goal-the goal being to cripple the British in Hong Kong. Everything indicates that Malraux must have been in close contact with some of the rev- 


\section{ANDRE MALRAUX: TRAGIC HUMANIST 21}

olutionary groups that were teeming in China and Southeast Asia. A wealth of experience in all aspects of revolutionary activity was open to him, and everything in his character indicates a man who would take the fullest possible advantage of the available opportunities. From this experience were to come two of his best-known novels.

In 1927, Malraux published an essay, D'une Jeunesse européenne, dealing at great length with some of the major themes of The Temptation of the West. In view of his later use of the term "tragic humanism," it is interesting to note that, at this time, the spectacle of the Occident reminded him of the ancient Grcek tragedies.

Malraux's first real novel, The Conquerors, appeared in 1928. The great Canton strike is the central event and to it comes a whole world of professional revolutionaries, drifters, terrorists, and Chinese pacifists-all of them overshadowed by Garine, a European adventurer acting as propaganda director for the Kuomintang. The story is seen through the eyes of another European coming to Canton to work with Garine. As will be typical of most Malraux novels, The Conquerors moves back and forth between violent action and extreme intellection. During the latter, the motivations of the characters are analyzed, both by themselves and by those who know them. By means of these discussions and with the aid of excerpts from his police dossier, we learn that Garine, as had his creator, had undergone a humiliating public trial and conviction for supplying money to finance abortions for unmarried mothers. The result of the affair is that he feels, not so much hatred for society, as disgust with what he feels to be its incurable absurdity. In consequence, he is dominated by a sense of his complete isolation from the rest of humanity, even from those for whom he is presumably working. Far from hampering his actions, this isolation makes it possible for Garine to deal summarily with whomever must be liquidated in order to assure victory. Garine himself executes one prisoner in order to encourage another to give information. He sees the 
strike culminate in success only to be himself cut down by that major antagonist to be found in all Malraux novels: death. When last seen, Garine is en route back to Europe to be treated for a fever he has contracted in the Orient, but it is known that he is too ill to reach there alive.

Although he is working closely with representatives of the Communist International, Garine by his very nature cannot be a true Communist, particularly as he despises what he calls the bolshevik mentality, "dominated by a stupid exaltation of discipline." He is an adventurer and, more specifically, one of "the conquerors" of the title, a man more interested in the intense activity of a revolution in progress than in the society that will follow. Leon Trotsky, already in difficulty with Stalin over the technique and conduct of revolution, severely criticized the novel, stating among other things that it was deficient as a chronicle of the events upon which it was based and that both Garine and the author needed a good dose of Marxism. Malraux replied that he had written a novel, not a history. He acknowledged some truth in Trotsky's remarks on Garine, but qualified this by adding that, while it might be unfortunate that there were more adventurers than professional revolutionaries at Canton in 1925, it was nonetheless true. Novelists who write of this type of individual appear to present something of a disciplinary problem for the party. Strelnikov in Boris Pasternak's Doctor Zhivago has more than a little in common with Garine.

As with all the novels that follow it, The Conquerors functions on a metaphysical as well as a physical plane, and although Malraux's ideas on the former were not yet completely formed-he later called The Conquerors an "adolescent's book" - the absurdity and fatality of the human condition permeate virtually every thought and action in the book. Man in Malraux's works is already engaged in a tragic struggle.

The tragic overtones are considerably deepened in his next novel, The Royal Way (La Voie royale). Abandoning politics as thematic material, Malraux draws on the experiences of his archaeological expedition into Indo- 


\section{ANDRE MALRAUX: TRAGIC HUMANIST 23}

China to paint an exotic picture of two men struggling with the jungle, wounds, savage natives, and the colonial administration to bring back sculptures from a Khmer temple deep in the hinterland. The tragic effect is strengthened by the physical isolation that concentrates all the attention on the two protagonists, Perken and Claude Vannec, and by the omnipresence of imminent death. All this is played against the background of the inexorable life and growth of the jungle through which they move, a jungle that seems to swallow up human effort even as it is being made.

Although there is no indication that Perken, the more important of the two men, has ever suffered trial and imprisonment, he, as was Garine in the earlier novel, is characterized by a sense of absurdity and isolation. And, like Garine, he is mainly interested in the most efficacious use of his own power, a power to be consolidated by the machine guns he hopes to buy with proceeds from the sale of the temple sculptures. It is as a form of power exercise that eroticism appears here for the first time in a Malraux novel. For Perken, the sexual act is essentially a domination of the woman by the man, and he equates a decline in sexual potency with a decline in life itself. Malraux has given his own interpretation of the nature of eroticism in his Preface to the French edition of Lady Chatterley's Lover and his study of Laclos' Liaisons dangereuses. He finds that in eroticism, as opposed to love, the domination and even humiliation of the partner is an important element, an approach that throws some light on an instance of infidelity that we shall see treated by both Clara and André Malraux. While Malraux's scenes of eroticism are as purple as any in French fiction, the importance and significance of eroticism in his works has been greatly exaggerated, as it has a role in only two novels, The Royal Way and Man's Fate.

The pattern of Perken's destiny is much the same as Garine's. Like the latter, he successfully accomplishes his immediate goal only to be cut down by a rather absurd side factor. He faces down an entire savage tribe and 
then is fatally wounded by stepping on a bamboo sliver placed by the same tribe. Thereafter death overtakes him slowly, but with the inexorability of true tragedy, heightened, as in the case of Garine, by the protagonist's lucid awareness of the full implications of his situation. That Malraux himself was thinking in terms of tragedy is indicated, not only by the ever present sensation of menace that colors the book from beginning to end, but also by the author's note that The Royal Way is the "initiation tragique" of a series. The series was never continued.

Structurally The Royal Way contains many points of similarity with The Conquerors. In both the story opens on a ship bound for the scene of the major action. As in the earlier novel, the main character is seen largely through the eyes of another man, who is working with him, in this case Claude Vannec, a young Frenchman. Vannec, however, is much more completely developed than the shadowy European in The Conquerors. He is involved in the action of the novel to almost as great a degree as Perken and his motivations are discussed at length, whereas those of his earlier counterpart were not even considered. As was the unnamed observer in The Conquerors, Vannec is present at the departure of the central figure; unlike him, he draws a metaphysical conclusion from his comrade's downfall. In part, his conclusion is that no promise of future life justifies the death of a human being.

It has been fashionable to treat Perken as a virtual embodiment of Malraux and his philosophy, but Claude Vannec probably contains even more of the author. He shares with his creator a genuine interest in archaeology, while for Perken the sculptures represent nothing more than the means to purchase machine guns. That Malraux was already interested in art and archaeology other than as a source of money or fiction is attested to by the appearance, in 1930, of his short work on Gothico-Buddhist statuary from the Pamir region. He demonstrates an acute and highly developed sensitivity to the artistic subtleties of the works in question. 


\section{ANDRE MALRAUX: TRAGIC HUMANIST 25}

Another Malraux-Vannec parallel lies in the fact that Vannec, also, has direct collision with the French colonial authorities. Several years had passed and considerable experience with the Indo-Chinese political scene had been acquired between Malraux's expedition and the appearance of The Royal Way. His activities during this interval appear to have given Malraux a good grasp of the realities of the situation. In the verbal exchange between Vannec and a French administrator, the former, angered by the obstacles put in his path, suggests that in thirty years the French administration may no longer be in Indo-China. In slightly less than that time, the entire northern section of the country had passed under the control of Ho-Chi-Minh and the Communists.

The first years of the 1930's were, as is always the case with Malraux, extremely active. By then he was an editor for Gallimard, but he found time nevertheless for trips to Japan, Afghanistan, and Persia, the last two furnishing source material for Clara Malraux's novel Par de plus longs chemins. In 1931, he disagreed in an exchange with Leon Trotsky over the implications of The Conquerors. Trotsky's criticism of his book did not prevent its author from protesting in the old revolutionary's behalf when his right to political asylum in France was revoked. Malraux's account of an interview with Trotsky reveals nothing but respect and even admiration for him. Malraux and Trotsky were not enemies in any real sense of the word, but Malraux's attitude in the affair demonstrates a chivalrous quality also found in his fiction. These who stand in the way of the revolution may be liquidated but never insulted or demeaned. It is a point of honor with Malraux that one does not vilify an enemy in order to fight him. $\mathrm{He}$ likes to recount an anecdote of Chinese origin in which members of one of two warring factions, forced to execute a respected encmy, ask him to do them the honor of being born on their side in his next incarnation.

Man's Fate, the last fiction that Malraux was to draw from his experiences in China, appeared in 1933. It is the novel most generally regarded 
as his best, and by some it has been hailed as the finest revolutionary novel the twentieth century has produced. The story turns around the Shanghai uprising of 1927, and the list of characters is, if anything, more international than that of The Conquerors. Like their predecessors, they are given to intellectual analysis of their motivations. In contrast with the gradual approach to action in the two earlier novels, $M a n$ 's Fate immediately plunges the reader into a scene of the most violent kind. Tchen, a Chinese terrorist, is about to murder a government official in order to obtain papers that will make it possible for the Communists to seize a boatload of weapons intended for the government forces. Tchen is a direct spiritual descendant of Hong, a terrorist in The Conquerors, but Malraux develops him further, and Tchen is possibly the most complex human being in all of Malraux's fiction. He represents, among other things, what happens to an Oriental when he is subjected successively to Christian and Marxist thought. If the individual, as in the cases of Hong and Tchen, comes from an oppressed group, the result can be a terrorist of the most intense variety. Tchen commits the murder and obtains the documents, setting in motion the chain of events that runs through the novel.

Around Tchen moves a whole group of highly developed and important characters, for, unlike The Conquerors, Man's Fate is not dominated by a single individual. More than anyone else, perhaps, attention is centered on Kyo Gisors, a Japanese-French half-caste charged with the organization of the communist combat groups in Shanghai. Kyo is assisted by Katow, a Russian, who has been involved in revolutionary activity since the early years of the century. Both of these men show a degree of humanitarianism not present in any of Malraux's earlier heroes. There are two relatively prominent female characters: Kyo's wife, May, a German-born doctor working with the revolutionists; and Valerie, mistress of Ferral, a French financier, who is trying to turn the events of the insurrection to the advantage of his Franco-Asian Consortium. As feminine characters, both of 
these women are defective since, with rare exceptions, they think, talk, and react along the lines of Malraux's very masculine philosophy. With respect to this, there is an interesting parallel treatment of the same subject in Mme. Malraux's Portrait de Griselédis. In both cases, the problem is an act of sexual infidelity by the woman and the man's reaction to it. Kyo's response to May's confession in Man's Fate is almost exactly the same as that of the Malraux surrogate in Portrait, both being based on the idea that the woman's passing lover now has the right to look down upon her. Clara Malraux's book shows little or no comprehension of the man's viewpoint. Man's Fate, in which the incident has additional philosophic implications, shows, if anything, even less understanding of the woman's position. None of Malraux's novels contains a really well-drawn female character.

A major part of the character analysis in the book is concerned with Kyo's father, an ex-Marxist university professor, at the time of the story virtually incapable of action and withdrawn into a world of opium dreams and oriental art. Among the others who people this teeming novel, one of the most interesting is Clappique, a European aristocrat gone to seed. Part mythomaniac, part buffoon, Clappique lives by his connections, his antique business, and numerous small deals, practically all of them illegal. This semi-absurd individual serves much the same function in Man's Fate as Garine's fever in The Conquerors and the bamboo sliver in The Royal Way in that he precipitates the catastrophe that eventually destroys both Katow and Kyo. Never seen but ever present in the novel is the man whose decision to break with and cxterminate the Communists embodies the action of destiny: Chiang Kai-shek.

As in the earlier novels, the action follows a rising line as the central figures move toward the accomplishment of their first goal, the seizure of Shanghai from within the city, while the Kuomintang army under Chiang advances on it from without. Although the insurrection is successful in this first phase, the impending doom of the communist groups is forecast in the 


\section{ANDRE MALRAUX: TRAGIC HUMANIST}

midst of the fighting when a courier informs Kyo that the party is no longer in the majority in the Kuomintang central committee. This is followed by Chiang's order that the communist combat groups must turn in their weapons, leaving them completely at his tender mercies. The communist high command, more concerned with long-range objectives than with the immediate welfare of the fighters, orders Kyo and his men to comply with the order. Kyo and Katow, aware of Chiang's sanguinary intentions and that surrender of the weapons will probably be just a preliminary to annihilation, return to the groups to salvage what they can of the situation. Tchen's abortive and suicidal attempt to assassinate Chiang adds to the latter's determination to eliminate the Communists, and a secret order is issued for the capture and execution of their leaders. Clappique hears of the order through one of his connections, Koenig, Chiang's chief of police, and is therefore in a position to warn Kyo and Katow. Here, though, the element of the absurd enters for he spends his time at the gambling table rather than warning the two men in time. Kyo and Katow are captured. Kyo cheats Chiang's executioners by taking cyanide. Katow, in an act that is an apotheosis of all he and Kyo have been struggling for, gives his poison to two young prisoners who are in terror of the death facing them. Katow is then led off to be executed in a manner singularly prescient of the crematory ovens that later were to preoccupy Malraux so deeply: Chiang has his prisoners burned alive in a locomotive boiler-a detail that lends credence to the oft quoted remark that history has come to resemble Malraux's novels. Both Kyo and Katow recognize the significance of their life and death during their final moments, while Kyo's father draws conclusions of a more metaphysical order from the tragic sequence.

When one reflects on Malraux's first three novels, it becomes clear that the tragic movement of purpose to passion to perception applies to all three and that they move closer to true tragedy as the element of perception increases with each succeeding work. Perception at the end of The Conquer- 


\section{ANDRE MALRAUX: TRAGIC HUMANIST}

ors is virtually nil, it is greater in the closing moments of The Royal Way, and it is highly developed in Man's Fate. There is also a dramatic pattern common to all three novels. In the early novels, action moves through a rising phase to the successful accomplishment of an immediate goal: the strike in The Conquerors, the temples in The Royal Way, the seizure of Shanghai in Man's Fate. Somewhere along the path to these goals there is an event that foreshadows the eventual destruction of the major protagonist, and these are strikingly similar in nature. In the first novel, it is the discovery of the mutilated body of Klein, a co-worker of Garine's. Perken finds his friend, Grabot, blinded and reduced to animality by the savage tribesmen. Man's Fate actually has two forewarnings: the announcement that the Communists have lost control of the central committee, and Tchen's attempt to kill Chiang, followed by a brief but vivid description of Tchen's battered body. The ironic nature of the instruments that trigger the ultimate catastrophes has already been noted. The doomed men go to their destruction but always with enlightenment. And someone is always left behind to mourn and to make philosophic observations.

If this sketchy pattern strikes one as vaguely familiar, it is probably because it is basically the same as that of Sophocles' Oedipus Rex, one of Malraux's favorite works and the play used by Kenneth Burke for deriving his purpose-passion-perception formula. Allowing for the changes that are naturally brought about by a time lapse of more than two millennia and the very different frame of reference, it is not difficult to see the formal elements that Sophocles' mighty tragedy gave to Malraux. Oedipus successfully discovers the murderer who has brought the plague down upon Thebes. His doom is forecast by the blind seer Tiresias (and Oedipus will blind himself) before it is sealed by the words of the messenger and the herdsman. If the fact that Oedipus himself is the murderer he is seeking is not absurd, it is, at least, ironic in the extreme. The catastrophe, at least partially, enlightens Oedipus and leaves Creon and the chorus to reach the 
philosophic conclusions. The latter's comments on the pain of human existence are strikingly similar to old Gisors' reaction to the death of Kyo.

The relationship of Man's Fate to Sophoclean tragedy becomes even more evident when one considers the stage version that was made of the novel in 1954. Although it was done in collaboration with Thierry Maulnier, many of the alterations show Malraux's unmistakable influence. Among the things that strengthen the connection with Sophoclean tragedy are the use of "a voice" (comparable to the chorus) for the narration of setting and background information, and the extreme stylization of the entire production.

Man's Fate won the Prix Goncourt for Malraux and made him the lion of French literary society for a time. However, the call of action was too strong to be long resisted, and he used his prize money to help finance an expedition to discover the lost capital of the Queen of Sheba. With Captain Corniglon-Molinier as pilot, he took off in a small, specially equipped plane to scout the wastes of southern Arabia. They returned with aerial photographs of a large ruined city that they believed to be the sought-for capital. In the spring of 1934, the Paris daily newspaper L'Intransigeant carried a ten-part account of the expedition written by Malraux and CorniglonMolinier. There was not a great deal of official archaeological reaction to the announced discovery and most of that was negative. Malraux limited his reply to a brief letter to an archaeologist who rejected the discovery, pointing out that it was a case of man who had never been to a given area contradicting one who had been there.

By this time Malraux had more serious matters to occupy him. The rapid growth of fascism, and, in particular, the emergence of Hitler's Germany as a great power, was gradually forcing the democratic countries into an increasing awareness of their peril. Malraux's association with the Communists became closer during this period, primarily because they were the most active opponents of the growing menace, at least on the surface. In spite of this close relationship, however, his speeches and articles at this 


\section{ANDRE MALRAUX: TRAGIC HUMANIST 31}

time reveal a man unable to accept the rigid, dogmatic position of the party line. He spoke at numerous party-sponsored congresses on cultural freedom and, more often than not, criticized the Soviets for the severe restraints they had placed upon artistic freedom. ${ }^{2}$ Even so, the party must have realized his value to their cause, for he was repeatedly featured as a speaker. One can obtain a good indication both of the warmth of the relationship at that time and its present chill from the actions of Louis Aragon, then, as now, the leading communist literary figure in France. He rose after one of Malraux's talks in 1935 to praise the accuracy with which he had put his finger on the heart of the problem. Ten years later, Aragon came to the Sorbonne to deliver a biting attack on Malraux's UNEsco talk, so forgetting himself in the violence of his charges that at one point someone in the audience interrupted him with a cry of "What is the subject of your talk?" Malraux's position had been essentially the same in both speeches.

The activity of these years was not limited to speeches in defense of culture. Malraux played an important role in groups organized to fight fascism and anti-Semitism. When the nazi courts condemned Georgi Dimitrov for the Reichstag fire, Millaux and André Gide went to Berlin to obtain his release. Never one to be unaware of irony, Malraux has noted that Dimitrov, in his turn, is now condemning innocent people to death. The mid-thirties also found Malraux traveling in Russia, where he became acquainted with Maxim Gorky. This was also the period of his defense of Trotsky's right to asylum, an implicit criticism of Soviet policy that no orthodox Communist would have dared.

If it was Sophocles who suggested the basic form of Malraux's first three novels, it was on Aeschylus that he drew for Days of Wrath (Le Temps du

${ }^{2}$ For an interesting first-hand account of Malraux's role at these various meetings, one should consult his friend Gustav Regler's The Owl of Minerva. 
mépris), which appeared in 1935. An apparently simple story that shows us a hero who is dragged away to isolation and imprisonment by two shadowy figures, and who in his delirium three times imagines a vulture descending upon him, it obviously recalls Prometheus Bound. The parallel is supported by the author's reference to Aeschylus in the Preface. The almost plotless story tells of Kassner, a communist intellectual, his confinement and torture in a nazi prison, and his eventual release when a comrade, in order to save him, tells the Nazis that he himself is Kassner. Malraux dedicated the novel to the German comrades who were suffering under nazi oppression, and there is reason to believe that, more than for any other, he meant the dedication to be for Ludwig Renn, author of the antiwar novel Krieg. In 1934, during his appearance before a meeting in behalf of the recently condemned Thaelmann, Malraux changed the subject temporarily in order to insert a series of remarks concerning Renn, who had just been imprisoned. Many of the key phrases in the speech occur in the novel, and the reason given by Malraux for Renn's adhesion to communism is also Kassner's.

Days of Wrath is the only one of Malraux's revolutionary novels that contains no criticism of communism; and, unlike Kyo in Man's Fate, Kassner never questions it as a doctrine. Nevertheless, it would be incorrect to assume that Malraux completely abandons the theme of human destiny in favor of political propaganda. Kassner is certainly good propaganda for communism; but far from considering it purely as an ideology or a historical movement, he sees it, as did Malraux, in terms of the overall human predicament. If the ethical and other questions relevant to the spread of communism are not discussed in Days of Wrath, we can assume that it is because, as the author states in his Preface, the type of work he was trying to write did not permit these complications. His next work was to be crowded with them.

The year after the publication of Days of Wrath, the Spanish Civil War broke out, and Malraux immediately joined the Republican forces. $\mathrm{He}$ 


\section{ANDRE MALRAUX: TRAGIC HUMANIST}

played a leading role in the organization of the air arm of the International Brigades and flew numerous missions, during one of which he was wounded. It would seem that Malraux was completely in his element. Gide, who talked with him during one of his trips back to Paris, reports that he did not seem tired and that he was less nervous than usual. According to Gide, Malraux felt as early as 1936 that only the disunity of the rebels kept the Republican situation from being desperate. Two days after the talk, he was back in Madrid deeply involved in trying to help pull together the disparate elements that made up the loyalist forces. Subsequently, although hampered by the inability to speak English well, he toured the United States to raise funds for the Spanish Republic.

Malraux was one of a considerable number of writers for whom the Spanish Civil War marked the beginning of serious disillusionment with the Communists. The conflict between his growing doubt and the necessity for a well-organized resistance to Franco is reflected in Man's Hope, which appeared in 1937 at the very height of the struggle.

The novel is an enormous fresco of the early stages of the war depicting multiple aspects of the Republican effort and containing an extremely large cast. It tells a number of parallel stories that have no direct connection with one another except the war itself and the common problem of converting the loyalist will to resist into an effective fighting instrument. Every shade of opinion on the Republican side is represented, from the Catholic Ximenès, through the convinced Communist Manuel, to the Anarchist Puig. Along with those who reflect specific groups are others who are in the war only for the adventure, and those who, without being committed to any special faction, have come to fight for a more just world. Typical of these last are Magnin and Hernandez, the former probably embodying more of Malraux than any of the others. As always with Malraux's protagonists, those in Man's Hope are far more intellectual and articulate than the average fighting man. They spend a great deal of time discussing their own 
motivations and those of others, as well as the conflict between ethics and the demands of political action. These parts of the book read like a broad and deep examen de conscience and inevitably call for comparison with Ernest Hemingway's For Whom the Bell Tolls and George Orwell's Homage to Catalonia, both of which strike a similar note. Hemingway's book is far more detached than Malraux's; and while the ethical-political conflict has a role in For Whom the Bell Tolls, it is slight compared to its all-pervading presence in Man's Hope. Anselmo's troubled conscience and André Marty's "mania de fusilar a gente" do not compare either in intensity or scope with the problems that confront, for example, Magnin and Manuel. If we say that For Whom the Bell Tolls is almost pure fiction derived from a modest personal involvement and Man's Hope represents both a greater personal engagement and a diminution of the fictional element, then Orwell's book is at the opposite pole from Hemingway's since the author is completely involved and the work is non-fiction. Homage to Catalonia is the product of a commitment so deep that the disciplinary struggle within the Republican ranks was pure anguish for its author and even reached a point where he had to flee for his life. Orwell ends on a note of despair while Malraux finds reason to hope; but Man's Hope appeared in the first years of the struggle while the Republic still seemed to have a chance for survival and before the purges had yet reached their highest pitch of violence.

When one considers Man's Hope as a whole, the term "fresco" seems particularly applicable. Time after time, the reader is struck by Malraux's striking visual images, a scene evocative of El Greco's Spain or Orozco's revolutionary murals. Often they are presented in such detail and careful composition that one feels that all they need in order to be hung is a frame. The technique is a completely conscious one to the degree that one of the characters, who is looking at a scene so described, remarks that it would make a magnificent painting. 


\section{ANDRE MALRAUX: TRAGIC HUMANIST 35}

Malraux transferred Man's Hope to the realm of the visual arts by making the book into a motion picture. Most of it was filmed in and around Barcelona with a cast made up largely of Republican fighters. Frequently the production involved great difficulty and even physical danger. Largely for political reasons, the film was not shown until after the Second World War. During the occupation of France, the Gestapo seized what they thought was the only print but they had the wrong film. When finally shown, it won the Louis Delluc cinema prize, and it is still a favorite with the cinema clubs that flourish in France.

Malraux extracted the maximum possible advantage from his Spanish Civil War experience. Not only was it transformed into a book and the book into a motion picture, but from the experience of making the picture he derived still another book, his Esquisse d'une psychologie du cinéma. Written in 1939, it did not appear until 1946, when Gallimard published it in a deluxe, limited edition. Malraux sees the motion picture as a logical descendant of the effort to capture motion that characterizes so much baroque art. However, as long as the camera remains fixed in one position and is recording movement within the same area, the cinema is not, according to Malraux, an art-it is only a copier. For him the art lies in the movement from one scene to another, change of angle, movement from distant shot to close-up, etc. As technical advances made greater freedom of movement possible, motion picture technique moved away from that of the theater toward that of the novel. After considering the motion picture as an art throughout this brief work, Malraux concludes by noting, not without irony, that "moreover, the motion picture is an industry."

Relations with the Communists, already strained by the events of the Spanish Civil War, the purge trials, and the restrictions on artistic freedom, were completely ruptured by the Hitler-Stalin Pact of 1939. Malraux has said that whatever may be the justification of the treaty from the Soviet point of view, it was a betrayal of the Western European proletariat. 


\section{ANDRE MALRAUX: TRAGIC HUMANIST}

As far as he was concerned, with the signing of this pact, the dream of an approaching internationalism went onto the junk heap, at least for the time being. In his own words, by becoming less French one no longer became more "man," one simply became more Russian. For better or for worse, Malraux the internationalist had become Malraux the Frenchman.

This nationalist orientation in Malraux was given still further impetus by the outbreak of the Second World War. The German invasion of France found him, at the age of thirty-eight, fighting as a private in the tank corps. He was captured during the battle of France and imprisoned at Sens. For the second time this man, for whom imprisonment was the penultimate indignity that one man can inflict upon another, found himself confined. He was no longer the intense youth of the Indo-China episode; and instead of being an isolated figure whose honor was being questioned, he was part of a large number of men who had lost a gallant battle against an enemy overwhelmingly superior in numbers and materiel. Nevertheless, this second confinement, as did the first, seems to have served as a catalyst in the crystallization of Malraux's thought. In The Walnut Trees of Altenburg (Les Noyers de l'Altenburg), written during the early war years, the experiences of the past twenty years come into focus. The human condition, implicitly a prison in the earlier works, is here explicitly referred to as such. And here, also, is mankind's inherent grandeur.

Malraux escaped from the German prison camp and made his way to the unoccupied zone. As might be suspected, he quickly became a part of the resistance movement and moved rapidly upward in command circles. Using the nom de guerre of Colonel Berger, he soon added still more luster to the legend of Malraux the fighting man. As was most of Malraux's other combat action, the Resistance was clandestine and hence provides us with only fragmentary information. Such evidence as we have leaves no doubt as to his ability, personal courage, and daring. Bergeret, a resistance leader subordinate to Malraux and commander of the Lot-Dordogne-Corrèze 
maquis, devotes several pages of his Messages Personnels to Malraux as a resistance chief. Perhaps more than anything else, Bergeret was struck by Malraux's utter nonchalance when personal danger was involved. He had his headquarters in a comfortable chateau known to everyone in the area, used far less than the ordinary number of guards, and apparently wandered at will through the region. According to Bergeret, Malraux ran his command with exceptional energy and skill, knew how to get the best from each man, and always seemed to grasp what had to be done and how to do it.

In the course of his resistance action, Malraux accumulated medals from both the British and French governments. He also accumulated new wounds, both physical and spiritual. His second wife, Josette Clotis, was killed in a rail accident, and his brother Roland, captured by the Germans, disappeared forever into one of the prison camps. Malraux himself was wounded in the leg while helping two British officers to escape and was captured and imprisoned at Toulouse. Freed by the liberation of that city, he returned to the French forces where he led the famous Alsace-Lorraine brigade throughout the action in the Rhine-Vosges area and during the advance into Germany.

The war years also saw Malraux's meeting with General Charles de Gaulle, an encounter that, with its subsequent developments, has determined Malraux's political action up to the present. Much has been made of the association between Malraux the long-time leftist and De Gaulle, portrayed by his detractors as the distilled essence of rightist thought. When all the elements of the situation are placed in perspective, however, the brouhaha over the rapport between the two men seems somewhat absurd. De Gaulle has now been President of France for some time, operating within the framework of a constitution tailored to his own desires; and, although he is a far stronger chief of state than the French customarily have, the personal dictatorship forecast by the extreme left has not materialized. Mal- 
raux, because of his long experience with the left, is far from being so naïve that he would fail to perceive the irony in the accusation of the French Communist party, the most authoritarian and Stalinist outside the SinoSoviet bloc, that De Gaulle has dictatorial tendencies. One finds in Malraux's political utterances of the last twelve years, particularly when they deal with this kind of accusation against the Gaullists, the same ironic note that pervaded his articles in L'Indochine enchaînée, but it has been polished by the intervening quarter-century of literary activity.

There are also a number of positive elements that have served to attract the two men to each other. De Gaulle's flat refusal to surrender to overwhelming odds, his struggle in the face of German might, the pettiness and incomprehension of many of his own countrymen, and the problems posed by his own allies make De Gaulle possibly the nearest thing this century has seen to an incarnation of Malraux's own vision of a man in a heroic struggle with destiny. Central to all of this is the concept of personal honor, a guiding principle for both men. For Malraux, enamored of great actions and disillusioned by the perfidy of the political instruments for carrying them out, De Gaulle, animated by patriotism and, whatever may be his defects, certainly without dishonor, was virtually made to order. For the general, Malraux, with his brilliant activity in many fields, may well harc secmed an embodiment of French cultural greatness, a concept which gives the opening pages of De Gaulle's Mémoires their remarkable tone.

From the beginning of this association, the pattern of Malraux's political activity has corresponded to De Gaulle's. When the general is active politically, Malraux occupies a position among his advisers or on his cabinet. As did his character Garine, Malraux usually functions in the area of propaganda and information, and also like the protagonist of The Conquerors, he emphasizes that he is serving as a technician, not as a politician. By preference he concentrates on cultural affairs both because 


\section{ANDRE MALRAUX: TRAGIC HUMANIST}

that is his main interest and because he feels a strong drive to make both his countrymen and the world aware of the French heritage. When De Gaulle withdraws from the active political scene, Malraux also goes into a semiretirement. The only other contemporary French political figure in whom he has shown the slightest interest is the energetic postwar premier who dared to tell the French some unpleasant truths: Pierre MendèsFrance. Malraux said that he saw in Mendès-France and those around him the possibility for the rebirth of French liberalism, a "new left." Even so, he made it clear that his own allegiance was to De Gaulle.

In the course of the war, Malraux published his last fictional work to date, The Walnut Trees of Altenburg. Like the print of his film L'Espoir, it seems to have undergone a series of adventures with the Germans but with a less fortunate ending. A prefatory note states that the Gestapo destroyed much of the manuscript and that the author reconstructed the book for the interest of bibliophiles.

In many respects it is the most autobiographical of Malraux's novels, giving in fictional transpositions a picture of the author, now older and more reflective, contemplating his life up to his capture by the Germans, assessing his experience, and determining its significance. All the familiar Malraux themes are here, but the action and intensity of the earlier works have been moved into the background to give a larger place to the atmosphere of reflection and meditation. With it we can say that the mathemata or perception phase of Malraux's literary career has been reached. After this, action as a source of experience is abandoned, and the series of works on the relationship of art to human destiny is begun.

Told by two generations of an Alsatian family named Berger (Malraux's nom de guerre), The Walnut Trees of Altenburg falls into three major parts, the second of which is divided into three subparts. The first and the last sections of the novel deal with the period of the Battle of France and show us the latter-day Malraux. Like the author, young Berger serves in the 
tank corps and is captured and imprisoned by the Germans. His experiences stimulate a meditation on man and human destiny. The philosophic background for this meditation is supplied by the middle section of the book, which deals with the preceding generation and mainly with young Berger's father, Vincent. It has been said that Vincent is modeled on T. E. Lawrence in whom Malraux has long been interested, but it takes very little transposition in time and space for Vincent Berger's career to correspond to Malraux's. The purely fictional incidents that have been added in order to illustrate certain points, such as a gas attack on the Russian front with its consequent demonstration of human brotherhood, have no counterparts in the lives of either Lawrence or Malraux. Service in the tank corps is the one common element in the lives of Malraux, Lawrence, and the younger Berger; and this is dismissed as being of no significance. Vincent Berger, the father, is a fictional device that permits Malraux to gain a perspective on his own life.

The key to the middle of the book, where the central philosophical problems are formulated, is the series of colloquia held at the Altenburg priory. To these meetings, only one of which is described in the novel, come a number of intellectuals active in different fields. At each meeting they deal with a specific aspect of the problem of man's destiny. During the novel, the main point discussed is: "Is there any over-all conception of mankind that makes sense?" These colloquia have a parallel in Malraux's own life. He often attended meetings of L'Union pour la Vérité where many of France's literary lights discussed similar problems. It would have been out of character for Malraux to believe that the greatest of these problems could be solved by such discussions. His skepticism, among other things, is shown by his irony-tinged portrait of the Altenburg colloquia.

Although The Walnut Trees of Altenburg may be inferior to Malraux's best novels, it has a beauty of its own and is particularly valuable not only as a recapitulation, but also as a prologue to the great books on art that 


\section{ANDRE MALRAUX: TRAGIC HUMANIST 41}

follow it. The seminal ideas and visions that characterize the latter are all marshaled here. Upon looking back over this book which reflects in part Malraux's most recent combat experience and which is the only one that ends in victory, one notes that there is nothing in it either of Malraux the Resistance colonel or of the final successful end to the war. There is only the soldier in battle, defeat, and imprisonment. True to the tragic pattern, it is not the triumph but the passion that leads to perception.

Following the war, Malraux married again, this time Madeleine Malraux the widow of his brother, who was killed during the war. Mme. Malraux is a lovely, cultured, and talented woman, who, prior to her marriage, had been a concert pianist. She and her husband live with their family in a comfortable home in Boulogne-sur-Seine, surrounded by the art objects Malraux loves so well.

Such was, until 1946, the year of Milraux's unesco speech, the life that, transformed into consciousness according to his own formula, produced the attitude toward human existence that he calls tragic humanism. It is a complex, intensely active life, crowded with everything from brilliant success to deepest tragedy. The tragic humanism growing from it is no less complex.

Malraux's life since this date has been only slightly modified from what it had previously been. There has been no more violent military or revolutionary activity, but his political life has been full and has probably produced as much controversy as did his earlier engagements. He became the subject of some of the hottest and most acrimonious debates and articles in postwar France. The official extreme left and its literary followers regularly accused him of having become a Fascist. However, neither his past life nor his subsequent actions justified this, so the arguments gradually lost their heat.

The urge to see other countries is still very much present. While there have been no more expeditions such as those to Indo-China and Arabia, Malraux has traveled to Sweden, Japan, Africa, South America, the United 


\section{ANDRE MALRAUX: TRAGIC HUMANIST}

States, and, probably, Persia, a country for which he has a marked fondness.

In the realm of writing, the postwar years have been, if anything, even more productive than the earlier ones. Malraux occupies a very important position on the editorial staff at Gallimard publishers, where he has introduced the work of Albert Camus, among others. He directs the "Galérie de la Pléiade," Gallimard's series of deluxe works on great painters and works of art. Aside from his own art books, which have been part of this series, he has edited volumes of the complete paintings of Leonardo da Vinci and Vermeer of Delft. As part of the preparation for the volume on Vermeer, Malraux conducted a long inquiry concerning the people who had served as models for the painter and concluded that the subjects in his greatest paintings were members of the artist's family. Malraux's interest in Lawrence of Arabia manifested itself in an essay first called "Le Démon de l'absolu" and later "N'Etait-ce done que cela?"; it has been published in part but never completed. The year 1947 brought Malraux's name back into the literary limelight with two works. One was a very suggestive introduction to a collection of Goya's etchings; but the far more important was the first volume of the Psychology of Art, Le Musée imaginaire, translated as The Museum without Walls. Called a psychology, though much of it is metaphysics, and an essay, when it often reads like poetry, it is the beginning of an as yet uncompleted series that has already made Malraux one of the most outstanding art critics of our time. As with Malraux's fiction, Le Musée imaginaire left few of its readers indecisive in their feelings about it, and public reaction was immediate and strong. Since Malraux's philosophy of art is an integral part of his over-all world vision and stems from ('xactly the same sources, much of the reaction to the book was colored by feelings about Malraux the man. Virtually everyone who reads his works on art becomes a strong partisan either for or against them. Part of this all-or-nothing attitude is due to their composition and style, which make 


\section{ANDRE MALRAUX: TRAGIC HUMANIST}

an analytical or partial approach extremely difficult. Along with the two volumes that followed in successive years, The Creative Act (La Création artistique) and The Twilight of the Absolute (La Monnaie de l'absolu), The Museum without Walls was soon translated into scveral languages, and it became one of the financial mainstays of Gallimard. Malraux himself, however, was far from satisfied with their form.

Goya has always been a source of fascination for Malraux; and, in 1948, he published a book-length essay on the Spanish painter, which he called Saturn. The briefest of glimpses at the painting from which the title is taken, or at any of the "Caprichos" or "Désastres de la guerre," reveals one of the reasons for Malraux's interest. The world of man's inhumanity and absurdity, from which much of Goya's work is drawn, corresponds to an important segment of the world of Malraux's novels.

Early in 1950, a fever that Malraux had acquired on one of his journeys recurred, sending him to bed and bringing him as near death as did some of his adventures. Vincent Auriol, then President of France and a political opponent of the Gaullists, sent his personal physician, who succeeded in putting the patient on the path to recovery. It was precisely the sort of chivalrous action that Malraux is most capable of appreciating.

The long period of convalescence gave him time to rework his Psychology of Art. The result, in 1955, was The Voices of Silence (Les Voix du silence), containing a new version of the three earlier works, plus a new volume, The Metamorphoses of Apollo (Les Métamorphoses d'Apollon). The Voices was even more successful than its predecessors, possibly because Malraux had made it easier to read. The poetry is reduced somewhat but still very much present. Malraux has said that he feels about art the way most people do about religion, and nothing attests to this more than the poetic, exalted, final pages of The Voices of Silence. The poetic feeling comes through even better in the recording he made of them.

The theatrical version of Man's Fate was one of the big events of the 


\section{ANDRE MALRAUX: TRAGIC HUMANIST}

1954 Paris season. Not only the play's political implications but also its techniques caused a minor polemic. In the serious French theater, the bienséances are still important and this modern tragedy with its machine guns and an on-stage murder violated a good many of them. There was a flurry of letters to the Parisian newspapers and a brief article by Malraux. Critics had a wide range of reactions to the play, but most conceded it to be an interesting experiment, at least.

During these years, Malraux contributed articles on politics and art to the weekly newspapers Carrefour and L'Express and participated in a Congress for Cultural Freedom, sharing the speakers' table in this last with Salvador de Madariaga, W. H. Auden, and William Faulkner, for whose novel Sanctuary he had written an important preface. Malraux's basic theme at the congress was that culture is composed of everything that makes man less a slave and more free, an idea we shall later examine in detail. Suffice it to say here that such a concept would be inconceivable to a Fascist.

By way of illustrating the unity of art in space and time that is basic to The Museum without Walls, Malraux produced his three-volume Musée imaginaire de la sculpture mondiale, which contains hundreds of plates showing sculpture of every conceivable type. Art as a world-wide phenomenon fascinates Malraux, and he has embarked on a multi-volume Universe of Forms (L'Univers des formes). In the accomplishment of this ambitious project, he hopes that no real art will escape him. The first volume of Malraux's last published work to date, The Metamorphosis of the Gods ( $L a$ Métamorphose des dieux), appeared in 1958. Classified as a metaphysics of art, it is characterized by what, for Malraux, is extreme clarity of writing, the desire for precision of expression having led the author to supplement the text with a table of the book's principal ideas.

When the Algerian revolt that returned De Gaulle to power broke out, Malraux was in Venice on an art project. He hurried back to Paris to be- 


\section{ANDRE MALRAUX: TRAGIC HUMANIST}

come in turn, Minister of Information, Minister Delegate, and Minister of Cultural Affairs in the De Gaulle cabinet. At present he is engaged in an intensive effort to renovate the structure of the French national theater and opera. He has stated that, along with a general development program, he would like to see the repertories cleared of many of the trivial and mediocre works that now litter them so as to make more room for new and experimental works as well as the great classics of France and other countries.

With the growing intensity of the French internal conflict that has resulted from the Algerian war, Malraux, as the government minister closest to De Gaulle and as the inhabitant of a relatively unguarded residence, has been a natural target for the plastic bombs of the Secret Army Organization. Both his ministry and his home have been attacked. And catastrophe of the personal variety continues to haunt him. During 1961, his two oldest sons were killed in an automobile accident.

Such, in brief, are the life and work of the tragic humanist with whom we are concerned. In the true sense of the Nietzschean phrase, his humanism, like all his work, is "Writ with blood." 



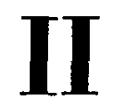

\section{HUMANISM AND TRAGIC POETRY}

Dare now to be tragic men and ye shall be redeemed.

-Nietzsche, "The Birth of Tragedy" 

WITH the emphasis placed heavily on the tragic, it becomes important to see how Malraux conceives of tragedy, its sources, nature, and results. By way of clearing the field, we can reject the notion that he sees it in terms of the greatest writers of French classical tragedy: Racine and Corneille. In the course of an exchange of views concerning Racine, Malraux declared to Henri de Montherlant that he was uncertain whether any Frenchman has written a tragedy in the Greek sense of the word. Continuing in the same vein, he noted that by tragedy the ancient Greeks mcant a poem of destiny; whereas, in his view, Racine's works are baroque poems. Corneille he sces as being preoccupied more with grandeur than with destiny with the consequence that his plays are not tragedies but "heroic poems." By itself this tells us very little. More significant is the fact that, although an examination of Malraux's writings reveals few mentions of his illustrious compatriots, one finds in them time and again comments on poetry, the Greeks, and destiny, usually phrased in a way that ties the three together and links them all to tragedy.

Remarks on ancient Greece begin very early in Malraux's works and continue throughout in a way that indicates the appeal that Attic civilization, in particular, has had for him. Ling, the Chinese traveler of The Temptation of the West, visits Athens early in his trip. He reacts negatively, finding Greek culture to be typified by the "harsh face of Minerva," symbolic for him of a will to lucid analysis and comprehension of man and the universe. He adds that the whole Occident is contained therein. All of The 
Temptation testifies to the disturbing results of this orientation, but it is to this approach to human existence that the European, A.D., swears life-long allegiance, and on this note the book ends.

We need not accept this early fictional work as the only indication that, for Malraux, ancient Greece meant primarily a humanity determined to understand itself, its world, and its universe-in short, its destiny. When the Psychology of Art brings him to a consideration of the Hellenic contribution to art, he calls this interrogation of destiny "the stubborn question that was the very voice of Greece.' Elsewhere in the same work, he adds significantly that Greek civilization was the only one prior to our own that gave primacy to interrogation. Malraux's culture of great navigators obviously has much in common with his interpretation of Greek culture.

Equally as frequent as Malraux's remarks on Greece are his comments on tragedy. Apart from minor items, such as seeing in Europe "a spectacle reminiscent of ancient tragedy" and calling The Royal Way "the tragic beginning of a series," we find him stating in his Preface to Days of Wrath that the world of that work is the world of ancient tragedy. In view of his statement to the critic Gaetan Picon that he considers the modern novel "a privileged means of expression of the tragic in man" and his reference, in his Preface to Manès Sperber's Qu'une larme dans l'océan, to the novel of our time as the spiritual descendant of ancient tragic poetry, we may safely assume that he envisions, not only Days of Wrath, but all his novels in terms of tragedy, and more specifically, of Greek tragedy. Two other remarks in Malraux's Preface to Sperber's novel provide us with clues to his interpretation of Greck tragic poetry. He asserts that every confrontation of the ephemeral with the eternal belongs to poetry and goes on to say that tragedy consists essentially of a confrontation, by means of facts, of man with the universe. The obvious conclusion is that for Malraux tragedy is automatically poetry. Several years later, in The Metamorphosis of the Gods, he synthesized ideas scattered through earlier works and declared 


\section{ANDRE MALRAUX: TRAGIC HUMANIST 51}

that "tragedy is poetry itself." His formula for defining the essence of tragedy is also the best conceivable description of Malraux's own works; for all of them, fiction and non-fiction alike, give us a vision of man aware both of his mortality and an eternity he can never attain. There are few more pointed illustrations of the ephemeral facing the eternal than old Gisors' meditation on the anguish of human existence: "All suffer and each one suffers because he thinks. Basically the mind conceives man only in the eternal, and the consciousness of life can be nothing but anguish." In Man's Hope Garcia, who-like his creator-is engaged in a savage war, restates this in terms of the tragic: "The revolution is tragic for the man who thinks, but life itself is tragic for such a man." A quotation from Napoleon, "Politics is the tragedy of our time," cited by Malraux in an essay "Etude sur Laclos," written at the time of the Spanish Civil War, provides an indication of one reason why Malraux's tragic novels are most often situated in the domain of political action and, incidentally, serves as a commentary on Garcia's remark.

The old axiom says that life is a tragedy for the man who feels and a comedy for he who thinks, but Malraux, who both thinks and feels, places the starting point of tragedy squarely in the realm of thought. In so doing he is being perfectly consistent with the Greek will to understanding that so repelled Ling in his contact with Athens. It is dangerous to read into a fictional character, or even a long series of them, a direct expression of the author's ideas, but this thought-produced awareness of man's lot is so often cchoed in the essay D'une jeunesse européenne and in the works on art that there can be no doubt that Ling, Gisors, and Garcia speak for Malraux. When, in The Voices of Silence, he contrasts man's brief existence with the eternal flow of the nebulae or writes that some day there will doubtless be no one to recognize the meaning of the stones of Florence, he is saying essentially the same things as his fictional creations and for the same reasons. Contributing in Malraux's case to this anguish of existence is the specter 
that haunts so many contemporary thinkers: the absurd. As the European correspondent in The Temptation of the West puts the matter, it is wrapped around us like the serpent around the tree of good and evil. It is a direct result of the effort, begun by the Greeks, to find a significant and coherent intellectual explanation of man's relationship to himself, his fellows, his world, and his universe. To the Greeks living at the beginning of this effort, the absurd was probably much less of a problem. To a large segment of moderns like Malraux, at the other end of more than two thousand years of this effort, it secms to have accomplished the opposite of what it set out to do by revealing the probability that no such explanation exists. For them the absurd is a very real presence and a genuine source of anguish.

Anguish, being the result of an intellectual approach to man and the universe, equals feeling and feeling is experience, so the process involved in the origins of this tragic sentiment of life is one that moves from intellection to experience. This order is of course the diametrical opposite of the experience-first pattern Malraux usually follows. However, where questions of man, mortality, and the universe are concerned, we are operating in a realm where there is apparently a wide choice of possible answers offered by religion, by science, and by reason. Perhaps the only experience that would lead to a definite choice from among the available possibilities is of the religious variety, such as mysticism or revelation. Malraux makes no claim to personal experience in this area. The occidental heritage left him a number of alternative possibilities, and it was probably feeling as much as anything else that determined his selection.

In the consideration of this primary phase of Malraux's tragic vision, two factors concerning the man himself are particularly worthy of note. First, the fact that the two works that most clearly delineate the sources of his tragic feeling, The Temptation of the West and The Walnut Trees of Altenburg, closely follow periods in which he suffered trial or imprisonment. The vital role played by prisons and related phenomena in his writ- 
ings leaves little doubt that such experiences (and here again experience assumes its primary position) had a major effect in formulating Malraux's vision of human destiny. In terms that we shall see him employ later, they forced upon him an awareness of fate. It is also significant that while the man who intellectually reaches a negative conclusion to the questions of man, God, and immortality usually calls himself an atheist, Malraux consistently refers to himself as an agnostic. Atheism is a negative statement, but agnosticism is essentially a question man addresses to the universe. Here again Malraux's thought shows its fundamental unity and the "stubborn question" finds an echo in him.

In all this there is a large element of feeling, and no one who has read Malraux's novels can fail to note the passionate intensity of feeling that characterizes them, particularly when the man-universe relationship is concerned. One of his finest descriptions of the tragic feeling occurs during the Altenburg colloquia:

We know that we did not choose to be born and that we would not choose to die; that we did not choose our parents; that we can do nothing about the passage of time; that between us and universal life there is a sort of gulf. When I say that every man is deeply conscious of the existence of destiny, I mean he is conscious, and almost always tragically so-at least at certain moments - of the world's independence of him.

Twenty years earlier, he had written, "The Greeks believed that man is distinct from the world." The feeling so common in Sartrian existentialism, of being de trop in the universe, is already implicit here.

For Malraux, Greek tragedy was an interrogation of a poem of destiny, and man is tragically aware of destiny. In 1954, he suggested to an interviewer from $L$ Express, "Perhaps the prestige of the novel is due to the fact that it is the art form which most powerfully opposes man to destiny." As a leitmotiv, the word destiny occurs and recurs throughout every significant 
thing that he has written to such a degree that it is clear that, for him, as for the Athenian tragic writers, it is the pivot on which all else turns. But what precisely is destiny as Malraux envisions it? It would be all too easy in the light of much that we have seen to equate destiny with death and say that man's fatal flaw is his mortality. But with the Greeks, as with Malraux, destiny is not simple but complex. Prometheus was immortal and death only a secondary problem to Oedipus. Death has a constant part in everything Malraux writes, but in one of the most poetic passages of The Voices of Silence he tells us, "Time flows, perhaps toward eternity, certainly toward death. But destiny is not death, it is made up of everything that imposes on man an awareness of his fate." The earlier version of these lines reads "nothingness" rather than fate, a significant change since, although man may count for nothing in the universe, within the scope of his own existence he is, for Malraux, imbued with possibilities for considerable grandeur.

This way of looking at human existence as being without significance on the universal level while at the same time giving it great value on the human one eliminates the apparent ambiguity from such paradoxical lines in Malraux as Garine's "a human life is worth nothing, but nothing is worth a human life." This key remark, which considers life from both the aforementioned angles, leads us closer to Malraux's interpretation of the nature of destiny. Mortality, which makes human life insignificant on the universal level, is without doubt destiny's most important aspect, forming the walls and bars of the prison that represents man's fate for Malraux. But when young Berger in The Walnut Trees of Altenburg says, "Once again my thoughts go back to Pascal," he points the way to further penetration into Malraux's vision of destiny and into the sense of Garine's words. It is precisely to Pascal's famous prison image of man's fate that Berger refers: A large number of men in chains, each of them repeatedly reminded of his inevitable doom by the regular execution of his fellow prisoners. In the 


\section{ANDRE MALRAUX: TRAGIC HUMANIST}

Pensées this passage is symbolic of human mortality, but for Malraux it has a double significance. First and foremost, of course, it has the same meaning it had for Pascal. But this aspect of destiny's destructive force still allows man the possibility of achieving a certain stature within the walls. Malraux himself has pointed out that much that is significant in Don Quixote, Robinson Crusoe, and The Idiot is due to the prison experience of the respective authors.

Man may be mortal and he may be absurd and insignificant from the cosmic point of view, but these factors, which we might sum up by calling the external aspect of destiny, still leave him with a last possibility: to give value and significance to life within the span of human existence-a Stoic immortality. It is here that the other edge of destiny's sword is turned and we approach the area of Aristotle's fatal flaw. Man's final possibility for grandeur is threatened by an element within man himself: his potentiality for evil. Prisons, chains, and executions-man-made items - are products of, and symbolic of, this inner flaw. By inflicting suffering and humiliation on others, one forces upon them an awareness of fate, thereby acting as an instrument of destiny and extending its action into man's life on earth. To the extent that this is done, the effect of destiny is complete and the human scene becomes absurdity and nothingness. There is no novel of Malraux's that does not contain imprisonment and death. Aside from his own experience with confinement, the second quarter of the twentieth century has been the age par cxcellence of prisons, torture, concentration camps, and executions. Everything has concurred to render his vision of destiny a more complex version of Pascal's image and to lend weight to the second half of Garine's observation.

In essence, this internal aspect of destiny is nothing other than another approach to the age-old theological and philosophical problem of the existence of evil, a problem that also deeply preoccupied Dostoevski. Malraux's position differs little if any from that of Ivan Karamazov when he 
56 ANDRE MALRAUX: TRAGIC HUMANIST

tells his little tale of the child and the general's dogs. He has quoted verbatim Ivan's declaration that, if salvation requires the suffering of one small child, he will have none of it. Here, as with mortality, theology makes explanations but in both cases Malraux finds them unacceptable. He applies the names "la bête" and "le démon" to this human potentiality for destruction and writes in Saturn that for an agnostic like himself the best definition of the latter is "everything in man that tends to destroy him." The entire ethical aspect of his humanism is a struggle to find ways of controlling the demon in man. Control only, for definitive solution there is none. Malraux regards man's demon as permanent, an everlasting part of his destiny. And that Malraux thinks of both the internal and external aspects of destiny as an integral whole is well illustrated by an observation in his essay on T. E. Lawrence, "N'Etait-ce donc que cela?": "Man is absurd. He is master neither of time, nor of anguish, nor of evil; the world is absurd because it implies the existence of evil, and evil is the sin of the world."

There is still a third phase of destiny, one which does not appear as constantly in Malraux's works as do the others. Man must struggle continually to wrest a living from the earth and to impose upon it the structures necessary to his existence. The earth, or nature if one wishes, moves continually to swallow up the results of this effort, and any significant lapse in the human struggle results in the virtual destruction of whatever advances have been made: another spectacle of man's ultimate fate. More than any other part of Malraux's activity, archaeology has put him in contact with this aspect of destiny; for archaeology is basically a rescue action, an effort to reclaim what nature and time have all but obliterated. This "rivalry between the earth and man's works" is another part of the battle with destiny that is Malraux's tragic humanism.

Such, then, are the major elements of destiny in Malraux's meaning of the term. Man, mortal and in a universe he has not chosen and in which he has no significant role, is bedeviled by his inner flaw and confronted 


\section{ANDRE MALRAUX: TRAGIC HUMANIST 57}

with evidence of the eventual destruction awaiting his efforts. For Malraux, the tragic sense is heightened by his feeling that two millennia of science and human reason have been almost completely unsuccessful, in any real sense, in dealing with these elements. There is still no real proof of a meaningful line between mortal man and the eternal universe; the inner flaw is still present; the struggle with the earth is as much a struggle as ever. There is no real reason why Malraux should seriously modify A.D.'s statement in The Temptation of the West that "after destroying God, and trying to annihilate everything that opposed man, European thought, after all its efforts, found itself face to face with death." The Voices of Silence will declare that "the human situation is not amenable to logic," and Le Musée imaginaire de la sculpture mondiale that "our epic of discoveries seems to have attacked the universe only to discover that the key to the cosmos is not the key to man." Worse, the sequence of great scientific discoveries, sinee it has not been paralleled by like advanees in the control of man's destructiveness, have made the situation more acute than ever before. As Malraux formulates the problem in The Voices of Silence: “Man's power to transform things began by making the world a giant construction yard and ended by making man's continued existence a question." ("Le pouvoir transformateur de l'homme commença par mettre le monde en chantier et finit par mettre l'homme cn question.")

Here Malraux's vision reveals his interest in Friedrich Nietzsche. The lattcr, with a vigor that equals if not surpasses Malraux's own, also attacked, in The Birth of Tragedy, the ability of science to resolve metaphysical problems: " And only after the spirit of science has been pursued to its limits and its claims to universal validity destroyed by the evidence of these limits, may we look for a rebirth of tragedy." And a few pages later:

Yet the noble and gifted man, even before the middle of his career, inevitably comes into contact with those extreme points of the periphery 
where he stares into the unfathomable. When to his dismay he sees how logic coils around and finally bites its own tail-then a new form of perception rises into view, namely tragic perception, which in order even to be endured requires art as protection and remedy.

With Nietzsche, as with Malraux, tragedy is tied closely to the idea that human reason comes to a dead end when dealing with the problems of destiny. Just under the surface of the Nietzschean lines, we find lurking the phantom that haunts all Malraux's works but most clearly in The Temptation of the West and D'une jeunesse européenne: the absurd. Both books were written well before the middle of Malraux's career, and his comparison of the absurd to the serpent wrapped around the tree of good and evil is reminiscent of Nietzsche's "logic biting its own tail." In The Royal Way, Nietzsche's "staring into the unfathomable" will become Malraux's rankling preoccupation with the unknown. Where art is concerned, Malraux goes far beyond Nietzsche. Although both agree that art is a major part of the struggle with destiny, Malraux assigns to modern art an important role in the attainment of tragic perception. The Voices of Silence gives as one of the functions of modern tragic art an effort "to tear away the gag with which civilization silences the voice of destiny"-in short, to challenge the Western optimistic faith in science.

Neither Nietzsche nor Malraux, who lives in an age of great scientific advances, is so unenlightened as to deny science a significant part in the human scene. As Malraux puts it in The Voices of Silence: "Not that a frontal attack has been made on science; what was questioned, devastatingly, was its ability to solve metaphysical problems." Just how devastating it must have seemed to him he had already made clear in 1927 when he wrote, "Since our civilization has lost hope of finding in science the meaning of the world, it is deprived of all spiritual purpose." Malraux's own spiritual odyssey is essentially the search for a purpose to replace those lost. 


\section{ANDRE MALRAUX: TRAGIC HUMANIST 59}

Emphasis on the scientific or rational approach to man's destiny produced a "theoretical world view" (Nietzsche) and "a culture with a preconceived idea of its own form" (Malraux). Nietzsche saw the tragic world view as diametrically and eternally opposed to the theoretical one. Malraux, as we have seen, feels that the tragic vision is the valid one because man cannot know where he is going. Few men have been more deeply involved in major events of the twentieth century than Malraux; and as he sees it, our time, with its unparalleled inhumanity, is a dramatic demonstration of the failure of science and reason to deal with the problems of destiny, and has brought the conditions that Nietzsche made prerequisite for a rebirth of tragedy. The principal intermediary between the "stubborn question" on which the Greek tragic vision remained fixed and the author of Man's Fate appears to be the philosopher who wrote The Birth of Tragedy.

This lucid tragic vision, this consciousness of destiny, reveals to man a picture of himself that is grim in the extreme: a long struggle that can never be definitively won, with probable annihilation as its conclusion. Such a vision could easily lead to nihilism, and in some of Malraux's early works the protagonists approach very near this precipice. Garine to some extent, and Perken to a greater degree, are engaged in intense activity, not to any really constructive end, but mainly because it dulls their anguished awareness of the absurdity and fatality of man's fate in general and their own in particular. At one point Garine tells his friend that activity makes him oblivious to everything else, including its own results - hardly an attitude on which to base a humanism. Scarcely better is the urge that drives Vannec to remark, "The game was beginning; so much the better, it would drive away the anxiety [inquiétude]." He is trying to avoid contemplation of, what for Girine is, "the vanity of all life" and, for Perken, the fact "that death is always there like irrefutable proof of the absurdity of life." In Pascalian terms-and if one harl to choose the French writer who has contributed most to Malraux's thoughts, it would be the author of the Pen- 


\section{ANDRE MALRAUX: TRAGIC HUMANIST}

sées-they are indulging in divertissements, "rushing toward a precipice while holding something before their eyes to keep them from seeing it." Destiny has dropped part of its mask and the sight is intolerable-or almost so.

Clearly, such action as this constitutes no revolt against destiny, does nothing significant about the mortality and absurdity of human existence. Nevertheless, early Malraux though they are and seriously defective humanistic heroes as they may be, Garine, Perken, and Vannec already have within themselves the element that saves them from complete nihilism and that eventually leads to Malraux's tragic humanism. When Perken says that he does not intend to submit, and Garine, that "the one important thing in life is not to be conquered," they are beginning the counterattack on destiny and uttering essentially the same cry of defiance that Aeschylus' Prometheus hurled at Zeus. Garine, haunted by the absurd, puts it in terms of his obsession, first in a particular and then in a general observation: "Even so, it secms to me that I am fighting against human absurdity by doing what I am doing here"; and, "One can live while accepting the absurd, but one can not live in absurdity." Obviously, Garine's own behavior is by no means entirely consistent with his self-centered remark on the anodyne effects of action. The last two quotations show a definite preoccupation with results, as does Garine's conduct throughout the novel.

With respect to the order of experience in Malraux's own life, The Conquerors and The Royal Way appeared in reverse order from the events from which they are derived. The archaeological expedition reflected in the later book preceded the political involvement that served as background for The Conquerors. The result is that The Conquerors at times seems somewhat more advanced along the path toward humanism and an involvement with society. Garine, with all his drawbacks, is acting with considerably more social purpose than Perken. Both books are products of a period when the author was moving from a rather pointless surrealism deeper and deeper 


\section{ANDRE MALRAUX: TRAGIC HUMANIST 61}

into the realm of political action. The second of the two, in spite of its less advanced philosophy, does, however, provide us with a more detailed description of the path by which a Malraux hero moves from tragic awareness and its resultant anguish to action that merits being called a revolt against destiny. At one point, Perken informs Vannec that he thinks about death, not with a view to dying, but with a view to living-an implication that awareness of mortality can lend intensity and direction to life. As Vannec mulls over his own feelings about the issue, the transitional process comes into sharper focus and we move one step further from the chasm of nihilism:

What could one do with the dead body of ideas that had dominated man's conduct when he believed that his earthly existence was useful towards some kind of salvation? What could one do with the words of those other cadavers who wanted to make their life conform to some model? For him, life's lack of purpose had become a basis for action. Let other men, if they wished, confuse this rankling preoccupation with the unknown with a complete surrender to chance. He wanted to wrest his own chosen images from the stagnant world that possessed them. What they call adventure, he reflected, is not evasion but a quest. The world's order is destroyed to reward man's will to profit from it, not just to let him give himself up to blind chance.

This, one of the clearest statements of its kind in all of Malraux's fiction, is, of course, only the thought of one of his characters, but the reasoning coincides so closcly with that of D'une jeunesse européenne, and the coursc of action called for corresponds so nearly to Malraux's own, that it is evident that Vannec here speaks for the author. Typical are the emphasis on will and the insistence that the real basis for the conduct of life is an awareness-unclouded by any comforting illusions-of man's destiny, absurd and mortal though it may be. Garine had already stated categorically that there could be no real strength or life without the conviction of the vanity of the world. 
Malraux's early fiction precedes by several years the rise of French Existentialism to prominence, but the attitudes implicit in passages such as those above will be restated later by Jean-Paul Sartre and others, many of whom, because of their association with the political far left, would be very reluctant to admit any debt to Malraux. Vannec, in trying to find a guide to life when all the systems have lost their validity for him, is in precisely the same dilemma of absolutely free choice that causes so much of the socalled existential anguish.

An awareness that human existence is pointless and absurd as well as mortal can and does lead to anguish, but awareness is not without major compensations in Malraux's works. As long as life is seen as moving along a path toward some ultimate goal, it is also characterized by restrictions and limitations designed to keep it on this path. All religions that emphasize immortality have a long list of things man must and must not do if he is to attain eternal life. But, the validity or non-validity of the individual restrictions as a guide to life is not the subject here; it is their limiting effect. When the ultimate purpose of life disappears, the restrictions disappear with it, and the result is virtually absolute freedom, the freedom to which Sartre says we are condemned. Within the flux of human events all things are now possible because there are no preconceptions as to where man is intended to go. Nietzsche's Zarathustra is heard again to say, "I have emancipated them from the bondage of purpose." This is the exact meaning of the last lines of Vannec's reverie, and Sartre said nothing different when he declared that existentialism is a positive assertion of Dostoevski's hypothesis that "if God is dead, all things are possible." Manuel, in the closing moments of Man's Hope, is bemused by the reflection that "even more disquieting than man's presence on earth is the infinite possibility of his destiny."

Destiny again, and still tragic-this freedom and possibility are nothing other than the unknown into which Malraux's "culture of great navigators" 


\section{ANDRE MALRAUX: TRAGIC HUMANIST}

is intended to sail. The vital element needed to begin the voyage is already present: the will to do so. Malraux, like Nietzsche, never ceases to hammer upon the all-important role of the human will in this movement from absurdity and anguish to genuine revolt in the battle to turn destiny to man's advantage. No character Malraux has ever created exemplifies this better than Kyo in Man's Fate. He requires that the Marxism for which he is working be viewed primarily as an effort of the human will, not as an inevitable historical evolution: "There is in Marxism an element of will and an element of fatality. Every time the fatality gets the upper hand over the will, I distrust it." In his addresses to leftist cultural congresses during the thirties, Malraux repeatedly made this same point. Malraux's objection, as voiced here by $\mathrm{Kyo}$, is entirely consistent with his tragic viewpoint. The term "fatality" smacks of destiny and its action and implies that Marxism is an inexorable and inevitable process that will automatically take place whatever man may do. Even apart from this tendency to make man a prisoner of a movement toward a given goal, it contains, to reuse Nietzsche's words, "a theoretical world-view." In 1949, feeling that the element of fatality has triumphed, Malraux referred to Marxism as a "Hegelianism oriented toward an uncontrollable future"-nothing could be further from the tragic effort of the human will that is the center of his own philosophy.

Thus far, it is quite justifiable to object that this philosophy may be all very well, but it could hardly be called a humanism, tragic or otherwise. As yet it seems to visualize merely the struggle of isolated individuals; it has nothing to tie it to mankind as a whole. To discover evidence of this very necessary unifying element, however, we need only turn once more to Malraux's remarks on Greek tragedy. He has indicated that Aeschylus is among his favorite reading, and in his Preface to Sperber's novel he states that Aeschylus' genius is inseparable from the man-universe confrontation that lies at the heart of tragedy. This same poet is his point of reference in the Preface to Days of Wrath, and laudatory comments on this first great 
writer of tragedy are scattered liberally throughout Malraux's works from the early thirties up to and including The Metamorphosis of the Gods. It is true that Aeschylus peopled his tragedies with many of the great figures of Greek history and mythology but one name appears time and again under Malraux's pen-Prometheus-and always in a way that suggests an association between Aeschylus' Prometheus and Malraux's own vision of man's plight. At one point in The Voices of Silence, talking of the meeting of great artists with the images that best express their central preoccupation, Malraux sets apart for emphasis Aeschylus' meeting with Prometheus. Later in the same work, he speaks of the Promethean cry that Europe, as represented by its art, is hurling at death. This is too much the vital essence of Malraux's own attitude for the reference to the Titan to be a coincidence. Allowing for a slight adolescence of tone, there are few more forceful cries hurled at death than the one uttered by Claude Vannec as Perken is dying in his arms:

Ah! If only some gods did exist so that he [Vannec] could, even at the cost of eternal damnation, howl, like a dog, that no divine thought, no future recompense, nothing could justify the end of a human life.

Nietzsche wrote that the Prometheus myth was the heritage of the whole Aryan world, and the vast number of contradictory interpretations it has had testify to the accuracy of his statement. A very large number of them see Prometheus as symbolic of the mind's power to eventually free man of all dependence, leaving him master of the universe and his own destiny, a conception with which Malraux would obviously not agree. It is in Nietzsche's own interpretation of the Aeschylean tragedy that we find the most important forerunner of Malraux's vision. In trying to go to the heart of Prometheus' personality, Nietzsche found that it was characterized by "a titanic impulse to become, as it were, the Atlas of all individuals, and on 


\section{ANDRE MALRAUX: TRAGIC HUMANIST}

broad shoulders to bear them higher and higher, further and further." He goes on to say that Prometheus Bound is a hymn of impiety, distinguished by its profound yearning for justice. Although Nietzsche's terminology here is somewhat grandiose, the impulse he attributes to Prometheus-the desire that all humanity, not just one man, attain its fullest possible stature-is the disciplinary element needed to turn the battle against destiny into truly humanistic channels. Without this "titanic impulse" or its equivalent, any man's struggle with fate remains at best an isolated event, at worst nothing but hedonism. With respect to this, The Voices of Silence contains a warning that is also implicitly a criticism of such carly Malraux heroes as Perken: "The individual who is thrown back entirely on himself soon perceives that he does not count for a great deal and that the 'supermen' whom he worships have all become very 'human.' " The unifying factor is all the more important because one aspect of the awareness of destiny is that man is isolated, not only from the universe, but also in a very profound sense from his fellow men. The "dead body" of ideas to which Claude Vannec referred not only linked man to some ultimate purpose, they linked men to one another around certain common elements in their interpretation of the human picture. The death of the body of ideas also means the death of the ties that bound men together, the result being complete isolation. A vital area of the action against destiny is the struggle to ovcrcome this isolation, obviously an impossibility as long as the fight is conceived in purely individual torms. Perken and Vannec dramatically illustrate this; pursuing purely personal ends, they are isolated from all of humanity except each other, and the end result of their action is virtually nil.

Garine has made a step away from such excessive egocentricity, but Kyo in Man's Fate is the first Malraux hero to take the all-important step of fundamental engagement in social action, a step by which the activity constitutes an effort to benefit humanity. As Kyo reflects on his role in the 
66 ANDRE MALRAUX: TRAGIC HUMANIST

world, we find that Prometheus' "titanic impulse" has become Kyo's "heroic sense":

For him the heroic sense was a discipline, not a justification for life. He did not suffer from anxiety. His life had a meaning and he knew what it was: to give to each of these men, whom at this very moment famine was killing off like a slow plague, the sense of his own dignity.

In terms that Malraux will use years later, what Kyo has done has been to choose action in the domain of "true values" as compared to that of "satiation," to do something that will give life value instead of indulging in a Pascalian divertissement. Dignity, as used here, is the key to the whole ethical aspect of Malraux's humanism.

Kyo is a tragic hero in the Promethean sense of the term. The Titan was punished for aiding humanity, and Kyo, guided by his heroic sense, gives his life in the same cause. In the final moments of a genuine passion, he experiences an enlightenment that makes him aware of the significance of his imprisonment and death. Vital, too, is the fact that, although (as do all Malraux heroes) he feels that human life viewed from the cosmic level is absurd, he also feels that by proper action it can be given real meaning within its own limitations. At this point awareness of destiny can serve as a spur to constructive action against its effects. Such is the real meaning of Nietzsche's "Dare now to be tragic men and ye shall be redeemed" and "There are heights of soul from which tragedy does not appear to operate tragically." Malraux and Nietzsche are both telling us that, in Malraux's words, "tragedy is the highest form of life affirmation." Associating these ideas specifically with Greek tragedy, Malraux writes that it produces "a simultaneous awareness of man's servitude and of his indomitable capacity for erecting his grandeur on this very servitude." The crucial role of con- 


\section{ANDRE MALRAUX: TRAGIC HUMANIST}

sciousness or awareness is made clear when, at another point in The Voices of Silence, he defines tragedy as "the intrusion of the world of consciousness [conscience] into that of destiny." The Pascalian influence, recorded earlier, is noticeable again here. Man's awareness of being crushed bestows upon him a grandeur greater than that of the unknowing universe that does the crushing. The role of conscience in Malraux's philosophy is so great that it is scarcely possible to exaggerate it. It is indispensable that in real tragedy the hero be conscious of his position and of what menaces him.

The period that saw the appearance of both Man's Fate and Days of Wrath (approximately 1932 to 1937) appears to have been extremely important in Malraux's intellectual development, and the interrelationships of tragedy, heroism, and humanism emerge as a central preoccupation. The Preface to Days of Wrath, which compares that novel to ancient tragedy, also further develops the concept of the heroic sense and links it closely to a union between the individual man and his collectivity. On June 8, 1935, Malraux conducted an entretien at a meeting of L'Union pour la Vérité on the subject of a "Heroic Humanism," subtitled "Concerning the Preface of Days of Wrath." Unfortunately, the text of this entretien secms to have remained unpublished. Title and subtitle, when combined with the actual contents of the Preface, are, however, sufficiently indicative of the general tenor: the conversion of tragic destiny into humanism by means of heroism. Several months earlier in commune, Malraux had written of "the positive hero"-he who risks his life for others; in the later paper he added that this was Prometheus' heroism. A series of remarks such as these indicates rather clearly that Malraux was visualizing the struggle for human betterment in terms of tragedy and the tragic hero.

That art, too, was being considered in this same light during this period is shown by the fact that, in his Preface to the French edition of Faulkner's Sanctuary, Malraux refers to the novel as the entry of Greek tragedy into 
the world of the detective story, and he also casts more light upon his version of the relationship of tragic art to its subject matter, destiny:

The tragic poet expresses what obsesses him, not to exorcise the obsession (the obsessive object will reappear in his next work), but to change its nature; for by expressing it with other elements, he makes the obsession enter the relative universe of things he has conceived and dominated. $\mathrm{He}$ does not defend himself against anguish by expressing it, but by expressing something else with it, by bringing it back into his universe.

A quarter of a century later in The Metamorphosis of the Gods, Malraux will condense all this by saying that tragedy is an attack on destiny by the poet's lyric power, as a result of which he gives form to that which crushes him.

For Malraux then, the tragic poet is the man who is both supremely aware of destiny and possessed of the will and ability to convert this awareness into something that shall bear the stamp of human effort. Specialists in the area of Greek tragedy may disagree with Malraux's interpretation, but no one except the most superficial reader could deny that the lines cited give a good description of his own works. By the time he came to write The Walnut Trees of Altenburg, he had pursued the connection between destiny and tragic art one stage further, saying that the latter is the possession of destiny by the poet.

This same novel contains the most highly developed example of the type of incident Malraux has used several times to dramatize man's conversion of destiny into art. We can refer to it as a "song of destiny" since music is involved in all cases. At one of the Altenburg colloquia, a participant tells of Nietzsche's being taken while dying and half-insane, by train from Italy back to his home. The train enters a tunnel, and as it does, Nietzsche breaks into an exalted song never before heard. His traveling companion, who is telling the story, adds that while Nietzsche's music was ordinarily medi- 


\section{ANDRE MALRAUX: TRAGIC HUMANIST 69}

ocre, this song was sublime. Occurring as it does in the midst of a discussion of man and his destiny, this anecdote leaves little doubt that the tunnel, with its chaos of darkness and sound, is intended to symbolize destiny; Nietzsche's song, the poet's victory over it. Malraux repeats the general form of this incident, altering the setting and details, in the Introduction to his Musée imaginaire de la sculpture mondiale. Here he tells of a deaf Becthoven, who has just shocked a companion with a blasphemy, being challenged with: "Who are we to talk like that?" The composer's reply is simply to sit down at the piano and play what Malraux refers to as the tragic opening notes of "Opus CXI." Other variations on this same theme occur in three novels. The Royal Way has a warrior chief leaping to his death in a snake-filled pit while singing his war chant. As in the two previous instances, the incident is not an integral part of the story. In all three they illustrate an idea, lending credibility to the belief that they are important to the author. He works parallel images more closely into the story in Days of Wrath and Man's Hope; although in the former, it is part of one of the strangest and most complicated passages in all Malraux's novels. Kassner, tortured and lying in his cell, slips into delirium. When in his delirium a vulture seems to descend three times to tear at his eyes, it is music that drives off the savage bird. ${ }^{1}$ In Man's Hope a loyalist soldier faces almost certain death from oncoming fascist tanks while in his heart he is singing a song of his native Asturias. Malraux appends, "Never will he know better what it is to be a man." Again in the same novel, old Alvear, awaiting possible death at the hands of Franco's Moors says, "If the Moors cnter soon, the last thing I hear will be this song of hope being played by a blind

'These attacks by a vulture on an imprisoned man constitute one more evidence of the influence of Prometheus Bound on Days of Wrath. One might even suggest that the bird's specific target has been moved from the liver, in Aeschylus' work, to the eyes, in Malraux's, because the liver, which was given an important role in man's intellectual and affective life by the Greeks, has no such significance for us. 


\section{ANDRE MALRAUX: TRAGIC HUMANIST}

man. It isn't the gods who made music, M. Scali, it is music that made the gods." Outside his window a blind man is playing the Internationale.

A tunnel, deafness, a pit, a prison cell and a vulture, a tank, blindness, and Franco's Moors-always there is something representative of destiny and its destructive action; and always there is man facing it and replying with art. The image is too recurrent not to be of major significance. It is symbolic of the obsession of Malraux the tragic poet; and as he said in the Preface to Sanctuary, the obsession will always reappear in the next work.

As Malraux wrote the art books that followed The Walnut Trees of Altenburg, he became increasingly preoccupied with art as a weapon against destiny. He told a newspaper interviewer that art was an anti-destiny and that ours is one of the first epochs to be aware of this. (It is in this light that we shall treat the aesthetic aspect of Malraux's humanism in a later chapter.) It is significant, too, that, although Malraux's works deal mainly with the plastic arts, when he wishes to discuss the art-destiny relationships of the Greeks, it is to their tragic dramas and not to their sculpture that he turns for treatment of the basic issues. In The Voices of Silence he writes that what the Athenian audiences admired in the dramatic tragedies was not the hero's defeat by destiny but the poet's victory over it. In one of the asides that he frequently and appropriately adds, he remarks that, after all, the audiences who saw Oedipus did not go home and gouge out their eyesthey returned to see the next production. The Metamorphosis of the Gods reveals no decline in Malraux's interest in the problems of tragedy nor does it show any shift in his interpretation. Tragedy still characterizes man's battle with destiny, and for him the mise en question of the universe remains the essence of Greece. What becomes even clearer in this most recent of his works is Malraux's idea that it is in man's will to create, as opposed to destiny's destructive action, that the source of the great tragedies lies. Tragedy as art, as poetry, speaks to destiny as one equal to another, and in a line that recalls Vannec's remark on the nature of adventure, Malraux 


\section{ANDRE MALRAUX: TRAGIC HUMANIST 71}

reiterates that tragedy is not submission to the tragic but conquest of it.

All this leans heavily on art and is, by itself, only one aspect of humanism. This emphasis on art during recent years has led some critics, particularly communist ones, to accuse Malraux of having deserted the world of social struggle to withdraw into the ivory tower of the extreme aesthete. However, the rapidity with which he dropped La Métamorphose des dieux to take a post in De Gaulle's cabinet clearly indicates that, as always with Malraux, no major element is ever abandoned, there is only a shift of emphasis. Malraux's thought has a fundamental unity, and the same complex destiny is the starting point for both his vision of art and for his tragic humanism. The idea of form and destination was applied to both human culture as a whole in his UNEsco speech and to aesthetics in The Voices of Silence when he states that "because it can not be preconceived, it is for the first time universal." And destiny, against which tragic art arose, is also the opponent against which his tragic humanism struggles: "It [destiny] is the obsession of the twentieth century, and it is counter to this that there is tentatively taking form, for the first time in history, the concept of a world-wide humanism."

Here the tragic vision begins to yield its full measure. Essentially it consists of pushing ahead in search of the answer to Nietzsche's question: "What can man do?" Since the question will only be fully answered when the last man is dead and therefore unable to know the response, it must necessarily remain an unending interrogation of human potentialities; for Malraux, this is the true meaning of humanism. The invalidation of all the preconceived structures for human existence that have shielded man from an awareness of destiny leads to the rise of the tragic awareness. It also restores the most profound type of freedom: the liberty to explore all possibilities without preconceptions as to where this exploration should lead. This attitude allows the humanism of an agnostic like Malraux to struggle toward universality and in so doing to move toward one of his long-time 


\section{ANDRE MALRAUX: TRAGIC HUMANIST}

goals: refutation of the Spenglerian hypothesis on the isolation of cultures. Religions, although they certainly do not mean for him what they do for their believers, can be encompassed within this humanism because it views them as efforts to deal with the problems of destiny.

Under these circumstances, it is not surprising that it is not the term "destiny" but rather "gods" that is, at times, ambiguous in Malraux's writing. Excluding his use of the latter term in the context of specific cultures, he uses it in two almost diametrically opposed senses when expressing his own ideas. Most often he employs the word "gods" as symbolic of the forces that created the universe in which man finds himself through no choice of his own. As such, the gods are an aspect of destiny. At other times, the gods represent something that man himself has created with the best that is in him to help himself move forward.

In spite of its great freedom, or rather because of it, this humanism remains the tragic humanism of Malraux's unEsco address. The struggle with destiny moves toward an unknown and unknowable conclusion and any victory is purely a relative one; as Malraux declares in The Metamorphosis of the Gods, "Destiny is eternally the winner; Aeschylus and the Olympian masters are dead." The eternal flow of the nebulae, Malraux's favorite image for the universe in which man is but a passing incident, will continue to move past long after the last of man's works has vanished. Any attempt to evade this places the entire picture in a false light.

In all this there may be, as religious critics have often claimed, the sin of pride or, since we have talked so much about tragedy, of hybris. If so, it is pride based on an essential humility, on an awareness of man's unimportance in the universe (a point that should be pondered by those doctrinaires who claim that his vision is one of pride, since most of these critics assign man an important and eternal role). Pride there is, but pride is what man can do in spite of the odds against him, and as such, it is an inspiration to carry on the struggle. Malraux recognizes that much of what he depicts 


\section{ANDRE MALRAUX: TRAGIC HUMANIST}

as a heroic human struggle is explained for religious believers by "some divine voice." He adds that "it is beautiful that the animal who knows he must die should wrest from the irony of the nebulae the song of the constellations and hurl it to the hazards of the centuries on which it will impose new and unknown words." The complete significance of this passage will be clear only when we have considered Malraux's aesthetics in detail. We need say here only that it is a poetic expression of his humanistic attitude.

The Metamorphosis of the Gods speaks also of an "eternal flow of man," a Stoic eternity to be sure, but one that is symbolic of man's will to struggle forward endlessly under the burden of his destiny. In the closing lines of his unesco speech, Malraux told his audience that for more than two millennia Western man has ceaselessly shouldered his load and departed into the night motivated by the will to consciousness and the will to discovery, and, he added significantly, communicating his discoveries rather than making secrets of them.

The obscure but profound and tenacious urge that man feels to carry on this battle is, as Malraux sees it, the key to man's true grandeur, a key that will probably never be fully explained. As he has grown older, his work has shown an increasing preoceupation with the nature of this drive. In an article written for the Dagens Nyhiter and again in the closing lines of the dramatized version of Man's Fate, he returns to the same problem.

If as the Stoics doubtlessly thought, the gods are only torches that man has lit one by one to light the way that removes him from the beast (or if the gods are totally unthinkable), the greatest mystery of the universe is in the smallest sacrifice, in the least act of pity, heroism, or love.

No one can keep from dying but only man can consciously give his life. It is less a question of sacrifice than of a sort of millennial communion against destiny, and the little lamp lighted amidst the indifferent flow of the constellations seems to me to keep watch over a vast and mysterious tomb. If God is dead, nothing is changed. If the world has no meaning, precisely 


\section{ANDRE MALRAUX: TRAGIC HUMANIST}

because it has none, all its derision can not prevail against the humblest act of justice, heroism, or love.

A millennial communion against destiny in a world without meaningthe sources and essence of Malraux's tragic humanism are all here. Destiny remains that which imposes upon man an awareness of his fate; and when, in the last pages of The Voices of Silence, Malraux gives his definition of humanism, we find that all the elements of the tragic struggle with destiny are present. Taking exception to Antoine de Saint-Exupéry's formula, Malraux writes, "Humanism does not consist of saying, 'What I have done no animal could have done,' but of being able to say, 'We have refused what the beast in us would have us do, and we want to discover man everywhere that we have found that which crushes him." "The active essence of this humanism that for Malraux is the reward of tragedy is to discover, develop, and exploit to the fullest the grandeur in man that makes such acts possible. He had already set this as the goal of his own tragic poetry when he wrote in the Preface to Days of Wrath, "But one may wish the word art to mean an attempt to give men a consciousness of their own hidden grandeur." 


\section{III}

\section{ETHOS, OR THE STRUGGLE WITH THE DEMON}

Violence is the sphinx by the fireside, and she has a human face. -Bronowski, "The Face of Violence" 

PERHAPs the greatest single element of unity in the works of André Malraux is their fundamentally ethical conception, a unity stemming from the fact that man's inhumanity to man is, for him, simply one aspect of a destiny that moves to reduce man to absurdity, dependence, and death. Like any humanist worthy of the name, he must try to give dignity and stature to man; but when man is as cosmically insignificant as Malraux interprets him to be, the problem of finding a minimum on which to base ethics is extremely difficult. Since the reduction of any individual detracts by that much from all mankind, Malraux has reached the conclusion that this minimum must be based on the value of the individual. By the very fact that an individual is a human being, possessed of a consciousness that makes him aware of suffering and humiliation whatever its source, he has, according to Malraux, an intrinsic value. The basis for Malraux's cthics is the recognition of this inherent value, which he calls human dignity. His ethical aim is an existence in which no man's dignity is violated. In the final analysis, this is not very different from Kant's first practical imperative that each man should be treated as an end in himself and never as a means. Philosophically, it can be debated that in Malraux's humanism the individual is being used toward an end: the greatest possible grandeur for the human race as a whole. On the practical level of human relationships, however, both the Kantian formula and Malraux's have the same purpose: to prevent any person from using another for his own ends. 
The ideal of a world in which no man's dignity is violated implies some sort of action to correct social situations in which the dignity of both individuals and groups is now being systematically abused. Unfortunately, it seems difficult, if not impossible, to take the necessary steps toward this ideal without violating the ethical minimum in the process. Yet another complication is the tendency of both individuals and organizations to begin by transgressing on this minimum for the loftiest of reasons and to end by violating it for their own purposes. They betray the very causes they set out to support and bring us face to face with one of the deepest ethical paradoxes concerning the use of force: its power to contaminate those who employ it. These are Malraux's basic ethical preoccupations. With their ramifications, they condition both his humanism and also the political activity deriving from it to such a degree that a discussion of his ethics inevitably involves a treatment of his interpretation of the ethics of the Communist Party with which he was so long involved.

Nowhere in his writings is the influence of the years Malraux spent in the Orient more marked than when he is dealing with the ethics of force; it is first seen, appropriately enough, in the exchange of letters between Ling and A.D. that makes up The Temptation of the West. At no time, however, does Malraux take the extreme position of some of the oriental philosophies that force should never be used, and it is noteworthy that even the Chinese correspondent in this early work feels that his country has need of it.

What is true though is that the years when Malraux was in most direct contact with the Far East and the philosophy of non-violence were precisely those during which he was moving toward the Communists and revolutionary activity. This apparent contradiction can be partially explained by the fact that this period also made him aware of social evils so extreme that they required immediate rectification. On the philosophical level it is probably due in part to the influence of Friedrich Nietzsche, a thinker with whose work Malraux was already in contact and whose ideas were the 


\section{ANDRE MALRAUX: TRAGIC HUMANIST 79}

direct antithesis of a passive attitude. The exact part played by Nietzschean philosophy in Malraux's movement toward and away from communism is difficult to ascertain exactly, but there is one conjecture that seems reasonable although the Communists themselves would deny the association. Nietzsche had written that anyone who wished to be a creator in either good or evil first had to destroy old values; the revolutionaries in the Orient were doing just that. A growing awareness that this same group was actually betraying the new values they claimed to espouse brought about the consequent rupture. Not only Malraux, but also Koestler, Hemingway, Silone, Orwell, and Spender, to mention just a few, had the same awakening and roughly at the same time: during the Spanish Civil War and when the Hitler-Stalin Pact was signed. For others, it waited until the brutal crushing of the Hungarian uprising. In Malraux's case, it was hastened by Orient-inspired doubts concerning the use of force. It was power and force which chained Prometheus to his rock.

The dilemmas relative to the use of force lie at the heart of many of the letters in The Temptation of the West. Ling feels that the complete philosophic rejection of force must be abandoned if China is to survive. A major reason for his trip to Europe is to search for a possible solution to this problem. Feeling that ancient Rome embodied an ethic based on force, he goes to visit its ruins. The result: "Alas, I had wanted to find there the strength my race needs so badly, and when I was face to face with its most beautiful image, I couldn't hide my disgust."

Ling's negative reaction to a political order rooted in the use of force is due not only to his oriental background, but also to an awareness of the dangers inherent in the employment of power; for we find in his remarks the same position as that taken by the philosophers of anarchism: power and force corrupt those who wield them and one can deteriorate to the point at which, far from being the master of power, one becomes its servant. A society based on power and force degenerates to a point where power 
becomes an end in itself and the members of the society nothing but a means of strengthening the society. The end result is the degradation of both the society and the individual, a degradation of which Ling sees a prime example in Rome: "This city teaches one to serve in order to dominate, a lesson fit only for crude soldiers. There is something base and vulgar in the acceptance of this ideal by an entire race. It troubles me to see men humbled like this. It is force that ought to be the servant and to something nobler than its own rigid allegory." Ling's words paint an accurate picture of the fascism that Malraux has fought for so long.

When ling visualizes force in the hands of his own oppressed countrymen, he becomes aware of still more of its dangerous potentialities. These people are familiar with nothing but suffering and injustice, and, particularly since they are conditioned in such a one-sided fashion, they have a natural desire for vengeance against the individuals and groups who are holding them down. On moral grounds it is impossible to deny their right to a more just and a fuller life. What happens, however, when power is placed in the hands of people with a background like this, particularly when they are led by someone who speaks in terms of the hatred and oppression with which they are so familiar? Ling asks this question about his native China. The answer, perhaps, is the mass public executions that followed the communist rise to power. The most violent of the current nationalist movements in which an oppressed people are incited by a demagogue are already forecast by Ling's quandary. To discover what Malraux feels is the answer to this question, it is only necessary to study Hong, a terrorist in The Conquerors. Driven by his hatred, he commits murders that damage the efforts of his own side; as a result, he is executed by the orders of the very men that he should have been aiding.

The Temptation of the West offers no solution for the paradox posed by the apparent necessity for force and the threat inherent in its use. One thing is certain, however: even at this early date, Malraux is aware that 


\section{ANDRE MALRAUX: TRAGIC HUMANIST 81}

force can be an aspect of the demon in man and consequently must be kept under constant guard.

Directly related to the problem of force is that of order, since one of the most frequent justifications for the employment of power is that it is being used to achieve order. Order most often takes the form of a political structure and thereby raises the problem of whether the individual exists for the order or vice versa. Ling's position is put in personal terms, but it states an ethical-political concept that Malraux will reaffirm at frequent intervals during his career. According to Ling, if he accepts an order, he wants it to be made for him, not him for it; Malraux has often said that the state exists to serve its citizens. This position is, of course, the direct opposite of the totalitarian ideal, be it fascist or communist; but it can be deduced with perfect logic from Malraux's vision of humanism as a struggle against destiny, a destiny that makes man aware of the dependence of his condition. It is to be expected, then, that Malraux would reject the stateindividual relationship that adds one more servitude by making the latter the helpless servant of the former.

Unfortunately, too, order is not necessarily good, for, as Malraux will say later, it also exists in prisons. In addition, it cannot solve the basic problems in man's struggle with the demon in himself. The level on which these must be dealt with is indicated when Ling declares, "People continually confuse the idea of civilization with that of order. Civilization is not social but psychological. There is only one true civilization: that of the fcelings." The concept stated here is one that Malraux will continue to develop and expand up to the present time. In essence, it means simply that the battle with man's destructive potentialities is fundamentally an individual one in which social, political, or religious structures have, at best, a secondary role. In the final analysis, each man must carry on the fight by and with himself. The Temptation is an early work, and Malraux has not yet used the terms "démon" and "bête," but Ling's remarks already 
imply a permanent element of Malraux's ethical attitude: no social order can extirpate man's destructive instincts.

One form taken by individual drives provides The Temptation of the West with another ethical subject for discussion; this is "the will to power," which Nietzsche believed to be the great force behind all human activity. Malraux diverges considerably from the German philosopher on this issue, maintaining a critical attitude toward the will to power which Nietzsche praises almost without reservation. Ling uses the simile "empty as a conqueror's soul" which condemns, by implication at least, the desire for power. The European, A.D., refers directly to the will to power in terms that are even more skeptical and derogatory, particularly in view of Malraux's numerous attacks on political dogmatism. He says that self-development with power alone as its end can be maintained only by continual adaptation, opportunism, or the acceptance of a political dogma. As is true with many of the themes in The Temptation of the West, treatment of the will to power is relatively brief. More complete development takes place in the longer works that follow.

One of the most interesting characteristics of The Temptation and one that will be typical of Malraux's writing is the tendency to put ethical problems in the form of questions. Actually, only two positive precepts can be derived from the letters under consideration: moral improvement is a personal rather than a social matter; and political order is made to serve the individual. The major difficulties, those related to the ethical use of force, remain unsolved.

In some respects The Conquerors is a dramatization of tentative solutions, and many of its characters incarnate different approaches to the rectification of social evils. As in the earlier book, we are presented with oriental passivity in contrast with occidental force and energy. There is also Hong, who combines, disastrously, the East and the West. At one end, there is the twentieth century's greatest apostle of passive resistance, 


\section{ANDRE MALRAUX: TRAGIC HUMANIST}

Mahatma Gandhi, to whom reference is frequently made in the novel; at the other end, are Garine and the representatives of the International, who are determined to accomplish the revolution by the most efficacious use of the force at their disposal. Although Garine's methods are ultimately employed, there is no inclination on his part to denigrate either Teheng-Daï's ideas or his character. In fact, it is noteworthy in this novel, where the motives of many of the characters are open to question, that those of Tcheng-Dai and his spiritual counterpart, Gandhi, are always respected. The former's entire life is viewed as a moral protest, while Gandhi is characterized as being motivated by a burning, painful desire to teach men how to live.

By the time The Conquerors appeared Malraux himself was involved in revolutionary activity, indicating that he had, temporarily at least, cast his lot for force as an instrument of social rectification. Nevertheless, the continuing debate on the subject indicates that he was fully aware of the dangers implicit in his choice. As in The Temptation of the West, there is cognizance of the menacing fact that in setting up a system for the most efficient use of force, the men whom it is supposed to benefit may become nothing more than implements. Tcheng-Daï does not want to see his countrymen used as subjects for an experiment in sociopolitical theory-to see them, as he puts it, "transformed into guinea pigs." In this he is taking on a national level the same position in the individual-order relationship that his compatriot Ling took on the personal one.

Garine, although he is affiliated with those using force and at one point even states that he is mainly interested in the best use of his own force, realizes that by carrying the idea of organization too far the organization may become an end in itself and the men nothing but tools. He excoriates Borodin for having set order so high that he forgets he is dealing with men. In one of the most frequently quoted lines from the novel, Garine says that the Russian wants "to manufacture revolutionists the way Ford manu- 
factures ears." Again, there is the danger that in struggling to elevate man in defiance of destiny, there is the risk of reducing him even further.

Nowhere in The Conquerors is the idea expressed that either the revolution or the new social order will improve man himself. The only reference to the subject occurs in Garine's analysis of Tcheng-Daï, and it more or less reiterates Ling's position. Tcheng-Daï, far more than Garine, is working toward a more just social order; and, in spite of his pacifism, he is not an advocate of a do-nothing stand. Like Gandhi, he hopes to achieve his ends by non-violent means. There is a close parallel bctween Tcheng-Daï's struggle through passive resistance and Ling's belief that civilization is based on the sentiments of the individual or, in Malraux's terms, on each man's victories over his own demons. Few, if any, means of action require more of a victory over oneself than does passive resistance to force. In contrast to the Communists in the novel who hope to attain human solidarity by mcans of a system imposed from without, Tcheng-Daï associates solidarity with the victory of the individual over himself. Garine goes so far as to say that this last is the only kind of action of which Tcheng-Daï is capable. The latter, however, carries the victory over the self to the ultimate, for, although unwilling to kill, he is quite ready to surrender his own life. When, like his real-life counterpart Gandhi, he is assassinated by an extremist, he accepts death so peacefully that those who discover his body are not certain whether they are dealing with suicide or with murder.

As the concept of human dignity develops in Malraux's works, it becomes more and more closely associated with the idea of fraternity, a relationship that is hinted at when Garine says that Tcheng-Dai associates his action with solidarity. For Malraux, no true solidarity or fraternity is possible except between those who are in possession of their dignity. Therefore, as he sees it, what must be done is not so much to treat with pity or compassion those who are denied equality by social injustice, but to try to raise 


\section{ANDRE MALRAUX: TRAGIC HUMANIST}

them to a level where solidarity is possible, to give them the dignity to which they are entitled. From Malraux's point of view this is infinitely preferable to the religious position that the oppressed must learn to bear their suffering; his position here is somewhat analogous to that of the Marxist attack on religion as an "opiate for the masses." In Saturn Malraux says that Goya hated the "peddlers of hope" in the Spanish prisons and most particularly those monks who came to comfort the prisoners. Malraux depicted an even more intense degree of this same feeling in Hong when he had him lash out with: "The life of a poverty-stricken man is one long torture, and those who teach the poor to put up with it must be punished, whether they are priests, Christians, or anything else." Hong is an extreme character even for Malraux, who will always reject a position that emphasizes the acceptance of suffering and injustice in favor of one that elects to struggle toward their rectification. To the degree that the emphasis shifts toward rectification, Malraux finds the religious approach more acceptable; in recent years he has come to feel great respect for the worker-priests who live with France's poor and try to alleviate their misery. As are all Malraux's stands, this one is easily deducible from his over-all vision of man facing a crushing destiny. In Garine's terms, "Suffering reinforces life's absurdity. It doesn't attack life, it makes it ridiculous." Garine is speaking here from the experience of his trial and imprisonment, the humiliation of which left him with the most profound feeling of absurdity of any of Malraux's heroes: "It was after the trial that the impression of absurdity the social order gave me gradually extended to include almost everything human." This, in turn, is related to the problem of isolation, for we find him adding, "There is no profound comparison for those men for whom life has no meaning. Walled-in lives." Man in the cosmos is a lonely isolated figure; men who have been imprisoned unjustly are just as isolated, both during and after their confinement, and afterward life becomes a long effort to 


\section{ANDRE MALRAUX: TRAGIC HUMANIST}

find the rest of humanity. Garine is cut off; the direction of Malraux's works after The Conquerors is toward the rediscovery of mankind, toward fraternity.

But Garine is human and therefore contradictory. In spite of all his talk about his isolation and the incurable absurdity of society, he makes repeated statements that indicate that he is trying to improve the lot of its downtrodden members. Many of these remarks show a strong ethical sense and strike the first notes of a theme that runs through all Malraux's works. Garine functions as a propagandist by "giving the masses the possibility of believing in their own dignity," marking the first time the concept of human dignity appears in Malraux's writing. It is not discussed in any detail in The Conquerors, but all of Malraux's literary creation is typified by this technique, musical in nature, of giving the introductory notes of a major theme in one work and orchestrating it more fully with each succeeding one. The importance dignity has already assumed in The Conquerors is shown not by further treatment of the word itself, but by a statement concerning the revolution in progress. Gerard, who had made the statement about Garine's propaganda activity, goes on to tell the narrator, "The revolution is giving to each of the members of the Chinese masses life itself." By comparing these words with Gerard's first sentence, which follows the same formula down to the use of the verb give, one can already deduce an important fundamental element of Malraux's ethical position. Individual dignity is so vital that true life is impossible without it; and consequently, to the degree that a man's dignity is violated, he is deprived of life itself. Garine, it will be recalled, has learned that while a human life is worth nothing on the cosmic level, there is nothing of equal value on the human level. Hence, the tragic dilemma of force is not only unsolved, it is intensified. Malraux will support revolution just as long as he feels that it is actually working to improve the lot of mankind as a whole. Once he has lost faith that this is true, the position is no longer 


\section{ANDRE MALRAUX: TRAGIC HUMANIST 87}

tenable. His fictional creation Garine, whatever his more personal reasons for participating in the revolution may be, believes that by so doing he is benefiting the oppressed Chinese masses. In one of his more exalted moments he tells the narrator, "I have created their hope. Their hope. I don't want to sound flowery, but after all a man's hope is his reason for living." It is perhaps significant that the novel marking the end of Malraux's revolutionary phase is called Man's Hope.

It is Garine, too, who first speaks directly of the necessity for remaining true to one's own beliefs, although it is implicit in the final lines of The Temptation of the West. During the course of a discussion with his friend concerning his actions and the reasons for them, Garine declares that "he is neither trying to be in the right nor to convince anyone, he is simply being loyal to himself." When revolutionary activity can no longer be combined with this fundamental loyalty, the former will be abandoned. Even this is forecast in The Conquerors when Nicolaieff, a party leader, accuses Garine of having too much individual conscience.

In the whole question of the relationship of individual conscience and political action, there is a strong parallel between Malraux and T. E. Lawrence on whose life Malraux has often written. Like Malraux himself, Lawrence engaged in a long campaign to rectify social injustice; in Lawrence's case, the domination of the Arab tribes by the Ottoman empire. Militarily Lawrence was victorious, but he felt that his original aims and his promises to the Arabs had been betrayed by the political maneuvering that followed the First World War. His life thereafter was a combination of self-immolation and writing. Malraux's life finds no parallel in the first of these, but the words in which he describes Lawrence's spiritual evolution could well describe his own. He sees in Lawrence a tragic man who sought "first in action and then in art to conquer the feeling of human servitude."

With all his defects, it appears that Garine has more moral and ethical stature than he is usually given credit for, particularly by those who 


\section{ANDRE MALRAUX: TRAGIC HUMANIST}

regard him as a typical example of the Nietzschean superman. For reasons already discussed, he is cut off from any real communion with the rest of humanity but does not feel that his isolation and lack of love of humanity keep him from acting effectively in its behalf. He asks whether a child should prefer a nurse who loves him but cannot swim and consequently has to let him drown, or a nurse who does not love him but who does know how to swim and saves him. A true feeling of human communion is generally lacking in The Conquerors, but there is progress in that direction. The next to the last word in the novel is fraternal.

If The Royal Way marks any development beyond the earlier novel, it is precisely in this matter of fraternity. Although they are isolated from the rest of the world, Perken and Claude Vannec are united in a human bond far superior to any found in Malraux's preceding works. This is the first of his stories in which the word fraternity appears with any real frequency, and the book leaves no doubt that the reference is to a brotherhood engendered by the common struggling against the forces that are trying to destroy the two men. The germ of Malraux's larger concept of virile fraternity, which is essentially that of a communion of effort against the manifestations of destiny, is, therefore, present in The Royal Way. At this stage it is limited to the loyalty of two men to each other. This is, however, a step forward, indicating that the process of the rediscovery of mankind is under way. One finds Perken declaring that loyalty is one of the few feelings he still considers valid, and reinforcing this by later stating that he "could count only on those men with whom he had a human bond, men for whom loyalty meant something." Garine could never have spoken of a human bond.

There is no question in The Royal Way of revolutionary action or social reform, and the problems involved in the restoration of human dignity are not even mentioned. Perken's goal, a personal mastery over the tribes in an area of Indo-China, is, in fact, the type of action that makes it necessary 


\section{ANDRE MALRAUX: TRAGIC HUMANIST}

to fight for human dignity. However, there is indication that Malraux still associates the imprisonment or humiliation of a human being with the operation of destiny, and suggests also that imprisonment and humiliation contribute to absurdity by the annihilation of lucid thought. The following is Malraux's description of a situation in which Perken and Claude Vannec are surrounded and confined by tribesmen intent on destroying them: "All precise thought was annihilated by those watching faces; the irreducible humiliation of man cornered by his destiny overwhelmed them."

Perken's situation, culminating as it does in his death, brings up another ethical problem central in any world vision that offers no promise of an afterlife. This problem, which greatly intensifies all the others, lies in the fact that if death ends human existence once and for all, there is, as of the moment a man dies, no possible rectification for anything he has suffered on earth. Perken, dying from the effects of a poisoned bamboo sliver planted by the owners of "those watching faces," is accutely aware of this. "He knew that he was going to die that nothing in the universe would ever again compensate for his past and present suffering. To be a man at all was even more absurd than to be a dying man." In Perken's dying hour, Malraux has succeeded in concentrating the whole metaphysical drama that lies at the source of his humanism.

The Royal Way also picks up the theme of the deleterious effects of wielding power. Perken is to some degree an example of this, but a far more extreme one is his friend Grabot. Grabot's whole purpose in life has been to exercise dominance over others and finally over a tribe of savages in Southeast Asia. Perken says of him that he probably defines power by the possibility of abusing it. This description of him is an indication of the man's moral degeneration, a decay that is given a physical counterpart when Grabot is blinded by the natives and tied to a post by a leash, like an animal, deprived of practically all human attributes. Many of Malraux's characters die in the course of his novels, but only two are reserved for 


\section{ANDRE MALRAUX: TRAGIC HUMANIST}

such final humiliation, and they are the ones who live by dominating others. The implication seems clear. The denunciatory note is strong when Perken says that Grabot "never thinks about anyone but himself. He is not really a person, but he is something to be considered." With this condemnation of the desire for personal power and of pure self-interest, the stage is set for Man's Fate and the heroic sense.

With the appearance of Man's Fate, Malraux's humanism, and consequently its ethical elements, can be said to have entered a fully positive phase. The factor that brings about this transition is precisely the heroic sense discussed in detail earlier. When it is first mentioned, in reference to Kyo, it becomes clear, not only what the heroic sense means, but also what rewards it offers him who is motivated by it. For Kyo life has a meaning, and he does not suffer the anguish of Perken and Garine. By its very nature the heroic sense bespeaks a human communion that contrasts sharply with the solitude that marks the earlier books. Essentially, the heroic sense acts by making one aware of the dignity of others and motivates one to fight for its restoration to those who are deprived of it. By so acting, one not only gives meaning to his own life but also to that of others and refuses to accept complete absurdity as the destiny of man. Although the heroic sense makes Malraux's ethic fundamentally one of participation, of human solidarity in which one functions as part of mankind rather than as an isolated factor, it does not imply that social action is the only way to achieve this end. For the time being, this struggle is Malraux's major preoccupation, but any activity that consciously aids humanity in its battle with any aspect of destiny can be said to be motivated by the heroic sense. The sine qua non is the awareness that one is part of man; in the Preface to Days of Wrath, Malraux makes it clear that in his opinion no real heroism is possible unless one is either a part of the collectivity around him or engaged in preparing the society that will follow. 


\section{ANDRE MALRAUX: TRAGIC HUMANIST 91}

Man's Fate is the first of the novels that attempts to define human dignity and, characteristic of Malraux, it is explained in terms of that to which it is opposed. When Kyo is asked by Koenig, Chiang Kai-shek's police chief, why he became a Communist, he replies that he did so in order to make dignity possible for those with whom he was working. Koenig then asks him what he means by dignity. Kyo's brief response is, "The contrary of humiliation." The essence of human dignity lies, therefore, in the absence of humiliation, in each man's ability to believe that he has a value that is recognized and respected by others-and this brings us back to the spirit of the Kantian imperative. Kyo translates this into terms of the workingman: "There is no dignity possible for a man who works twelve hours a day without knowing why he is working." In a review of Ilya Ehrenbourg's Sans reprendre Haleine, Malraux will state specifically that the revolution is the first step toward the conquest of human dignity.

In Man's Fate, as in The Conquerors, it is made clear that in depriving a man of his dignity by humiliating him, one is also cutting him off from the rest of the world. Even Koenig is aware of this, for the author makes the comment that "he [Koenig] had seen enough derelicts from the civil wars in China and Siberia to know what a negation of the world results from intense humiliation." As had most of Malraux's characters, Koenig had learned through experience. He had been publicly tortured and humiliated during the struggle between the Whites and the Reds that marked the latter stages of the Russian revolution.

The pages of Man's Fate that tell of Kyo's imprisonment prior to his death emphasize even more strongly the fact that a man who is completely dependent upon another and, therefore, a means rather than an end in himself, is humiliated and, in a sense, stripped of his real self. Those who are imprisoned and tortured are no longer fully men. Again it is evident that this suffering, inflicted because of the demon in man, reproduces the same 


\section{ANDRE MALRAUX: TRAGIG HUMANIST}

feeling of isolation and humiliation as that caused by an awareness of man's absurd, dependent position in the universe. It is a fatalité, duplicating the action of destiny.

He felt almost like vomiting from the intense sensation of humiliation that a man feels when faced with another upon whom he is entirely dependent: powerless against that unclean [immonde] shadow with the whip. Stripped of his own being.

The jailer's abjection didn't seem real to him; and yet at the same time, he felt it was an unclean [immonde] fatality, as if power alone were enough to change any man into a beast. Those dark beings swarming behind the bars like the crustaceans and giant insects of his childhood dreams were not men either. Total solitude and humiliation.

The use of the very strong adjective immonde twice, both times in reference to the jailer, leaves little doubt of the author's position vis-à-vis men who thus reduce their fellows. And into these few lines are packed still other of Malraux's preoccupations. Kyo's conjecture about the reason for the jailer's abjection harks back to Ling's statements on the dangers of possessing power. The description of the other prisoners has a conscious Goyesque, nightmare quality that effectively deprives those unfortunates of all humanity and underlines strongly the horror that such inhumanity evokes in Malraux. For parallels in painting and literature one must turn to Goya's Caprichos and Desastres de la Guerra and to some of Dostoevski's more intense descriptions of human depravity.

The close relationship between humiliation and solitude has already been discussed; but lest there be any doubt that the former causes the latter in this case, it must be pointed out that Kyo is not physically separated from his fellow prisoners-he is lying between two of them, one of them his close friend, Katow. His isolation is a spiritual one, resulting from the humiliation of his position. The fact that the solitude and humiliation are total 


\section{ANDRE MALRAUX: TRAGIC HUMANIST}

indicates that this suffering has destroyed the last vestiges of dignity and left Kyo in prison, like man in the universe, isolated and absurd. His father's remark "that all suffering that aids no one is absurd" echoes Garine's statement in The Conquerors and points out that when one inflicts pointless misery the absurd is brought into human existence. From Malraux's point of view, the ultimate destiny of man is, of course, death. Thus, when the suffering inflicted on one man by another ends in the death of the victim, destiny's destructive action has been duplicated from one end to the other, a duplication of which Kyo shows his awareness when he declares, "Suffering can have no meaning except when it does not lead to death, and that is where it almost always leads."

Old Gisors' statement leaves open the possibility that suffering can have meaning if it aids someone; Kyo's, if it does not end in death. Oddly enough, Kyo's suffering and death are a contradiction of his own remark but a confirmation of his father's. In the closing moments of his life, Kyo is well aware of this, and his awareness shows the high degree to which Nalraux's ethic has become one of participation, for the idea in question is that of martyrdom for a cause. Like the church itself, both Malraux and his creation Kyo are fully cognizant of a martyr's value to a cause. At this point the novel moves to a point where religious fervor and revolutionary zeal are almost indistinguishable in their external manifestations. Crane Brinton deals in detail with this similarity in his Anatomy of Revolution; Malraux shows, in Man's Fate, that he is aware of it by having Kyo say that the suffering of his comrades and himself will become a "golden legend." Other indications that he understands the parallel are in his lumping together of the "early Christian" and the "Soviet worker" in his Preface to Days of Wrath, and in the elder Alvear's declaration in Man's Hope that "the revolution is playing for some men the role formerly played by eternal life, a fact that accounts for some of its characteristics."

Actually, both Kyo and Tchen think of their own deaths in terms of 


\section{ANDRE MALRAUX: TRAGIC HUMANIST}

martyrdom but with an essential difference in their approach. The impact of Tchen's martyrdom is reduced because he actually planned it in advance to give added weight to the revolutionary writings of one of his companions. This kind of carefully premeditated self-sacrifice smacks of suicide and is somewhat suspect. In Tchen's case, he was motivated largely by serious personal problems that had nothing whatever to do with humanitarianism. One of the results is that in his agony and death Tchen is as alone as he had been all his life. The same, however, is not true of Kyo. $\mathrm{He}$ is as aware as Tchen of the value of his death, but, unlike the latter, he did not plan it or seek it. It came to him, not because inner conflicts gave him a desire for self-immolation, but because he was struggling for a better world. Much of the description of Kyo's last moments is reminiscent of scenes of early Christians waiting for death in the cells beneath the Roman arenas:

He had fought for what, in his time, made the most sense and contained the most hope. He was dying among those with whom he had wished to live. Like each of these reclining men, he was dying because he had given his life a meaning. What would a life for which he would not have accepted death have been worth? It is easy to die when one does not die alone. Death saturated with this fraternal murmur, an assembly of the vanquished in which the multitudes would recognize their martyrs. A bloody legend from which would come golden legends.

These lines reflect to an amazing degree the ones in which Nietzsche says, "The consummating death I show unto you, which becometh a stimulus and a promise to the living. His death, dieth the consummating one triumphantly, surrounded by hoping and promising men." And what a far cry it is from Perken, dying in the arms of Claude Vannec, uttering his last words: "There is no death, there is only I who am going to die." In deaths such as Kyo's, the highest ethical demand of Malraux's humanism 


\section{ANDRE MALRAUX: TRAGIC HUMANIST 95}

is met; for even though life is lost, it is essentially one that is given more than one that is taken. The over-all cause of human dignity has been advanced in its struggle against the demon in man.

At the ethical antipodes from Kyo stands Ferral who not only would never sacrifice himself for others but in almost every sense lives by humiliating his fellow man. The very fact that Ferral is a capitalist in a novel with a strong Marxist slant is in itself indicative of the author's attitude with respect to him. Nevertheless, Ferral is not denounced in the typical communist fashion with such terms as "exploiter of the masses," though they would certainly be accurate in his case. As are all of Malraux's important characters, he is explained in terms of his deeper motivations, of which his drive for money and power is only one external manifestation. He is condemned, not in terms of communist theory, but in terms of his own actions, which violate the basic tenets of Malraux's ethical position. How far he is from Kyo is best shown by a question he asks of the latter's father, a question including a condition that Kyo will later fulfill: "Don't you think that it is typical of the stupidity of the human race that a man who has only one life can lose it for an idea?"

Ferral is incapable of thinking in terms of anything except his own selfinterest and the satisfaction of his personal desires; therefore, a position such as Kyo's is completely incomprehensible to him. This is emphasized by the fact that Gisors actually had an answer to the foregoing question; but it consisted of one of Kyo's ideas, and "he didn't feel like discussing Kyo's ideas with Ferral." The idea in question is based on the concept of human dignity and shows once more the degree to which Malraux's heroes, even when they are Communists, function, not as an expression of party doctrine, but as elements of the author's vision of human destiny. Kyo's idea is couched in terms of the human condition, not of the class struggle. "A man can very rarely tolerate his-what shall I call it?-his human condition. He [Gisors] thought of one of Kyo's ideas. Everything beyond 


\section{ANDRE MALRAUX: TRAGIC HUMANIST}

self-interest for which men will accept the risk of death tends to justify this condition by basing it on dignity: Christianity for the slave, the nation for the citizen, communism for the worker."

Virtually everything Ferral says and does indicates that he has no conception of the dignity of the human individual. By itself this shortcoming shows a lack of basic ethical values, but it is not necessarily destructive. Unfortunately, this defect, when confined with an egocentricity such as Ferral's, easily leads to the violation of the dignity of others. Gisors believes that everyone defines intelligence by what he wants most in life. For Ferral it means, "possession of the means to force things and people." What Ferral really wants therefore is to be able to use others as a means to his own ends, a goal that he attains with notable success throughout ninetenths of the novel. He lives by inflicting humiliation on others, whether they are employees, or his mistress, Valerie. Malraux, writing in his Preface to Lady Chatterley's Lover, states that in eroticism as visualized in Lawrence's novel "the individual is no longer anything but a means." These words also define Ferral's amatory relationship with Valerie. Basically, the driving force in Ferral's make-up, even where his eroticism is concerned, is nothing more or less than the will to power. And his definition of intelligence is in reality a definition of power. By simple deduction it becomes clear that, in Malraux's terms, the desire for personal power is, at the very least, a potential danger to human dignity and a strong temptation to the demon in man.

Malraux's treatment of the will to power in Man's Fate shows how vital the heroic sense is in his ethical stand. Gisors, who serves as a porte-parole for many of the author's most important ideas, considers the will to power as only the intellectual explanation of something far more fundamentalthe desire to escape the human condition. Translating the desire for power into the terms of Ferral's definition of intelligence, Gisors tells him: 


\section{ANDRE MALRAUX: TRAGIC HUMANIST 97}

Moreover, men are perhaps indifferent to power. What fascinates them in the idea, you understand, is not real power, but the illusion of being able to do whatever they please. A king's power is that of governing, isn't it? But men don't want to govern, they want to force. You said so yourself. They want to escape from the human condition, I tell you. To be more than a man in a world of men. Not powerful, all-powerful. The chimerical sickness, of which the will to power is only the intellectual justification, is the will to deity: every man dreams of being God.

The exercise of power acts then as a drug that gives man the illusion that he is free from the action of destiny, that there are no limits to what he can do to satisfy his desires. As such, it is just one more intoxicant along with opium, intense action, eroticism, and mythomania, which are found throughout many of Malraux's novels, the intoxicants that, according to Gisors, only Kyo is able to resist. Unfortunately, the will to power is more dangerous than the others, because it is universal (note Gisors' language with respect to this: he speaks of men, not some men) and because indulgence in it entails the violation of the dignity of others. Malraux made Ferral a good dramatization of the menace inherent in this problem, but Albert Camus carried it to its logical conclusion in his play Caligula. "A man who has any experienced power," according to Dostoevski, "and the possibility of humiliating another creature with the deepest kind of humiliation somehow loses control over his own sensations. Tyranny is a habit; it can develop, and it does develop, ultimately into illness. The best man in the world can become crude through habit to the point of bestiality." Both Gisors' definition and Kyo's worry about the effects of power are contained herein. Kyo and Ferral are both men, and each would, of course, like to escape the human condition. The difference between the two is that Kyo is disciplined by the heroic sense with its concomitant awareness of human dignity, while Ferral, who in any real sense is completely undisciplined, is 
motivated almost entirely by a search for intense sensations, either through eroticism or the struggle for financial power. Like any discipline, the heroic sense exacts a price and acts as a limiting factor on the realization of desires that are present in all men.

In the preceding chapter we stated that, for Malraux, the heroic sense would lead one to choose action in the field of true values rather than satiation. Moving ahead for a moment to The Voices of Silence in which Malraux discusses the nature of the two fields, it becomes clear that Kyo's conduct fits the pattern of the former, Ferral's that of the latter. What is likewise evident is that Malraux sees both fields in terms of the human condition and that Kyo's idea on the "justification of that condition" is an early statement of Malraux's "domain of true values."

The domain of satiation (assouvissement) is not one of values but of sensations. It knows only a succession of instants; whereas arts and civilizations have linked man to duration, if not to eternity, and have tended to make him something more than a surplus inhabitant of an absurd universe.

Satiation is very different from the feeling upon which civilizations base their relationships with the cosmos and death. Men satiate their tastes, but they are devoted to their values. The true ones are those for which they accept poverty, derision, and, sometimes, death.

Long before Malraux had fully developed either the idea of the heroic sense or the two domains of action, they were already implicit in germinal form when he wrote in The Temptation of the West, "Voluptuous pleasure and novelty easily seduce mediocre minds, but they would be powerless against those who are prepared to combat them." Kyo, as his father remarks, is prepared; Ferral comes under the classification of a mediocre mind, which, to a man driven by the will to dominate, would be the most humiliating of appellations. 


\section{ANDRE MALRAUX: TRAGIC HUMANIST 99}

The author's position with respect to the ethics of Kyo is quite clear and is perhaps best shown by his treatment of the final end to which each comes. While this would more often than not be an excessively naive approach to interpretation, Malraux's remark to Edmund Wilson to the effect that he created his characters to incarnate ethical values gives the method added weight where his creations are concerned. It has already been noted that the keynote of Kyo's death is fulfillment-even exaltation. Ferral, on the other hand, is humiliated, first by his mistress, later by men to whom he had to go for financial aid. The incidents in which Ferral's humiliation takes place are worthy of note, not only because, like Grabot's fate, they are vivid dramatizations of a Malraux ethical lesson, but they are also demonstrations of the author's ability to incorporate his idea in two widely different settings. In one, Ferral, sexually stimulated, goes to Valerie's hotel expecting to find the mistress he had previously subjected completely to his domination. He finds instead an absurd caged bird left by Valerie to ridicule him. The effect on Ferral is described in typical Malraux fashion: "Ferral's power, his lucidity, the audacity that had transformed IndoChina, all ended up with this bird, which was as ridiculous as the universe itself and which obviously didn't give a damn about him." In one short sentence Malraux has made his ethical point and brought the whole affair back to the absurdity of man in the universe.

The other incident, the last time Ferral is seen in the novel, has a tone similar to the scene where Perken and Vannec are cornered by the savages but with the setting changed from the jungles of Indo-China to those of high finance. Ferral is in Paris seeking money to enable his Franco-Asian Consortium to adapt to the new conditions brought on by Chiang Kai-shek's victory. His future is completely dependent upon the decision of the ministers, and this places him in the humiliating situation where he had so often put others. 


\section{ANDRE MALRAUX: TRAGIC HUMANIST}

But he was beaten; and having made efficiency his own central value, nothing would compensate him for being faced by these men whose persons and methods he had always despised. He was weaker than they were, and consequently, in terms of his own system, everything that he thought was in vain.

As with Perken, "all lucid thought is annihilated by those watching heads." Ferral has been "cornered by his destiny." In Malraux's terms, force and order, the major components of Ferral's central value, efficiency, are not true values at all. The Temptation of the West had already condemned them as ends in themselves.

The moral to be drawn from this long comparison between $K y o$ and Ferral is clear. Malraux is declaring that the only path to life that makes sense and gives real satisfaction lies in action whose purpose is to give the utmost possible dignity to mankind as a whole, to do all one can to prevent absurdity from being man's ultimate destiny. Not the least of the rewards for a life lived by these standards is the feeling of virile fraternity, a brotherhood in mankind's common effort; for, although Malraux's vision of human existence remains one of an unending battle against destiny, Man's Fate tells one that "combat is the strongest of all bonds." On the other hand, the worst way of life is one that involves the satisfaction of personal desires by means of the humiliation of others; such action represents a triumph of the beast, a defeat of man by the internal aspect of destiny, and leads to the eventual isolation of both the perpetrator and the victim.

Man's Fate picks up other ethical precepts laid down in earlier works. Perhaps the most important of these is the necessity to win without betraying one's basic principles. As might be expected, it is Kyo who makes this point. In the speeches made to the coolies he is organizing, he tells them that they "must be Marxists, not in order to be in the right, but in order to win without betraying themselves." Absent here, as it always is when Mal. raux writes of Marxism as such, is the obnoxious tendency, not only of 


\section{ANDRE MALRAUX: TRAGIC HUMANIST 101}

Marxists, but of followers of other faiths, political and religious, to assume the absolute moral rightness of their own position. Such assumptions are the source of a political and religious Manicheism.

Although Man's Fate is evidence of Malraux's decision to resolve, at least temporarily, the ethical doubts concerning the use of force, there are indications in the novel that he is still aware of the menaces inherent in the use of violent methods. One of the most serious of these is the danger of becoming contaminated through contact with violence. Even Tchen, terrorist that he is, is aware of this; for after murdering the government official, he tells Kyo, "In murder, it is not the killing that is difficult, but avoiding degeneration, being stronger than what happens within oneself at that time." Although the motivations are entirely different, the opening pages of the novel, which describe Tchen before, during, and after he kills, are reminiscent of nothing so much as Dostoevski's plunge into the mind of Raskolnikov as he prepares, executes, and reacts to his murder of the old woman in Crime and Punishment. Almost always when Malraux moves to penetrate those parts of the human psyche where the darker passions, the power of the demon, lurk, his guide is not Freud but Dostoevski.

One ethical area in which Malraux is both like and unlike Dostoevski is the problem of whether or not men should be taught to accept suffering. Although Dostoevski presents the reader with such characters as Ivan Karamazoff who attack the Christian position on the matter, he himself is essentially Christian and tends to treat suffering as a means of spiritual purification. This bestows upon it a desirable quality that would incline one to accept rather than fight it. Even so, the arguments with which he provides those who believe the contrary are so dramatic that Malraux, whose final conclusion is the opposite of Dostoevski's, goes to the great Russian writer for illustrations of his own point of view (for example, the story cited earlier of the baby and the general's dogs). The people in Malraux's novels who attack the Christian stand have, themselves, always had some 
contact with Christian teaching. With Hong this is mentioned only in passing, but Tchen, who takes a similar though slightly milder stand in Man's Fate, is carefully provided with a background of instruction in the faith. Tchen's broader knowledge, quite possibly a reflection of the author's increasing maturity, tends to make his denunciation less virulent than his predecessor's. When his ex-mentor, Pastor Smithson, asks Tchen what political faith will account for human suffering, the latter simply replies, "I would rather reduce suffering than account for it. The tone of your voice is full of humanity. I don't like the humanity that comes from the contemplation of suffering." The key to Malraux's attitude toward human suffering lies, perhaps, in Tchen's use of the word contemplation. Malraux's whole life and work bear witness to his awareness of the value of suffering, the passion phase of the tragic dialectic. This, however, is not sought for its own sake, nor is it passively accepted. Here the passion (pathemata) of the tragic pattern can be deceiving; the suffering is passive in the sense that it is something undergone, not in the sense that there is no reaction against it. Both accounting for suffering in the religious sense and contemplating it confers on suffering a respectability to which both Tchen and his creator object. Tchen's remark may represent a one-sided approach to the Christian attitude on suffering, but it is one that is consistent with the tone of Man's Fate as a whole, a tone characterized by a sense of the urgent need for direct action and a feeling that contemplation, temporarily at least, must be pushed into the background. Gisors, although he lives much of the time in a world of opium-induced serenity, realizes this sufficiently to state that "today, serenity is almost an insult," a remark that illustrates the author's feelings about man-inflicted human suffering, the tone of the book, and his attitude toward the struggle for social justice. Where both Man's Fate and its author are concerned, it portends an effort to try and raise at least part of humanity above the humiliation and absurdity to which the demon in man has reduced it. There 


\section{ANDRE MALRAUX: TRAGIC HUMANIST 103}

has been debate over Malraux's actual participation in the Chinese revolution, a debate we are in no position to settle. About his deep involvement in action against fascism and anti-Semitism, an action he was just beginning, there is no question. This full participation that marks Man's Fate, a major advance over the earlier novels, paves the way for Days of Wrath, the novel that is to follow.

Attention has already been called to the parallel between Kassner and Prometheus, both of whom were imprisoned because they sought to aid mankind. Although Kassner's willingness to accept martyrdom, if necessary, in order to advance his cause is the most important example of selfsacrifice in Days of Wrath, it is not Kassner himself who carries self-sacrifice to the extreme. In this there is remarkable similarity with Man's Fate, in which it is not Kyo, the most important character, who makes the supreme gesture, but a lesser one, Katow. Katow would have been executed in any case, but somehow the gift of his cyanide to his two terrified comrades is more moving and effective than the comparable incident in Days of Wrath. This is very possible because the reader knows Katow as an individual and because his action is a human, personal one. The unnamed character in Days of Wrath voluntarily suffers martyrdom, not so much for Kassner himself, as for the cause that Kassner serves. Although it is by no means the best-done example, this last is the most extreme case of selfsacrifice in all Malraux's works and the one in which the similarity to Christ is most obvious. Both the tone and the wording of Kassner's exclamation when he finds out the reason for his release bring to mind their biblical counterparts: "A man had given himself for me. How derisive it was to call brothers, men who had nothing but blood in common." As always for Malraux, the emphasis comes back to human brotherhood.

The role of fraternity is even greater in Days of Wrath than it was in Man's Fate, and its nature is treated in more detail. These discussions leave no doubt that virile fraternity is the brotherhood created by the common 


\section{ANDRE MALRAUX: TRAGIC HUMANIST}

struggle to lift man above absurdity, suffering, and humiliation. At one point this is stated directly and at another point Kassner refiects that "he had always had a deep taste for friendship. However, the feeling that they were united, not in their persons, but in their common passion, moved him still more."

In Days of Wrath it becomes still more apparent that there is a very close relationship between dignity and fraternity; and it emphasizes that imprisonment and humiliation not only destroy dignity, but bring with them isolation and a consequent loss of communion. That it takes time to rediscover the rest of humanity after such experiences is shown by Kassner's reaction after his relesase. "Kassner had begun to rediscover the world; but the idea that he had been [in prison] only a week separated him from the world again. Reality was like a language that he had known and forgotten by turns." Kassner may have been in prison for a very short time, but time for someone in prison is not the same thing that it is for a person who is free. In a passage that evokes Baudelaire's Quand le ciel bas et lourd pèse comme un couvercle, Malraux depicts the crushing effect of time spent in prison on the human spirit.

For prisoners, the passing of time, that black spider, oscillated in their dungeons as atrocious and fascinating as it was for their comrades who were condemned to death. Kassner suffered less in the present than in an obsessive future, in a perpetual "forever" that the closed cell door and his absolute dependence made more penetrating than the cold, the darkness, or even the crushing effect of the stone walls.

Those who inflict such suffering on their fellows are different from other men only in that the demon in them gained the upper hand. Like Kyo, Kassner finds that there is nothing to distinguish the guard who beats him from other men. Kassner reflects that he "was certain that he would be faced with cruelty or the will to humiliate; however, he was scarcely able to distinguish in his face anything other than the look of a slave buyer." 


\section{ANDRE MALRAUX: TRAGIC HUMANIST 105}

The implication, therefore, is that this evil is potential in all men, an aspect of the ever-present demon; it is not the attribute of any special type or class of men. "The executioner," said Dostoevski, "is to be found in every modern man." The "will to humiliate" was a fundamental driving force in Ferral's make-up; however, where men such as the prison guards shown in Days of Wrath are concerned, Malraux condemns them in terms that leave no doubt as to his feelings. After a passage involving Kassner and his torturers, Malraux inserts, "In every country it is the most ignoble men who choose this job."

These evils are simply different aspects of a cruelty that is present in all men, signs that the demon has taken over in some of them and caused them to torture, humiliate, and thereby isolate men from their fellows. Strong and dangerous though this destructive element in man's nature is, there is another that is equally strong and that tends to counteract it: fraternity. Malraux intervenes directly in Days of Wrath to declare that "no human word is as deep-seated and profound as cruelty, but virile fraternity goes just as deep into the blood itself, into the hidden areas of the heart where torture and death are crouched and waiting." Implicit in these lines is a reaffirmation of Ling's belief that civilization is essentially an improvement of individual feelings, that like the demon in man, the capacity for fraternity is an inherent quality and that like any other quality, it can be developed-a concept that will have increasing importance for Malraux. At this stage, however, he is feeling his way toward an ever-increasing unity among his important ideas of the heroic sense, virile fraternity, and human dignity. The preceding quotation makes virile fraternity virtually synonymous with Kyo's heroic sense; both are essentially the same in the struggle for human dignity. The author's effort to link dignity closely to the heroic sense and fraternity is reflected in a passage that defines it, like fratcrnity, as a force opposed to suffering. Kassner's thoughts in The Days of Wrath show that the process of association is not yet complete: "In a confused 


\section{ANDRE MALRAUX: TRAGIC HUMANIST}

way he thought that man had succeeded in being man, in spite of the dungeons, in spite of the cruelty, and that perhaps only dignity could be opposed to suffering."

Dignity, fraternity, and the heroic sense are so inextricably interwoven that they can only be regarded as aspects of an integral whole, a whole whose purpose is to give sense to human existence and to counteract the absurdity and humiliation of man's fate by permitting man to realize the utmost possible stature that destiny permits. In short, the foregoing quotation, primarily ethical in nature, contains, by implication, the whole core of Malraux's humanism. In part, it forecasts his definition of humanism as "the refusal of what the beast in us would have us do." That, at the time of Days of Wrath, he was using its preface as the basis for a talk on "heroic humanism" was not a matter of chance. Malraux's fraternal reunion with the rest of mankind was now complete.

This great feeling of human fraternity laid the groundwork for Man's Hope, drawn from an event, the Spanish Civil War, which many regard as one of the finest examples of fraternal action against a threat to human dignity that the world has yet seen. In the novel itself, this movement by individuals of many lands to defend the people of Spain against fascism is referred to as the "apocalypse of fraternity," and the word "fraternity" occurs countless times throughout the book. For men like Malraux, it apparently seemed as though the moment had finally arrived when men of good will would co-operate to fight the forces of humiliation and destruction. This is the dominant note of the first part of the novel; and it gives this section its title, "The Lyric Illusion" (L'Illusion lyrique)-translated with unequaled silliness in one American edition as "Careless Rapture." Although Man's Hope appeared before it became obvious that this great hope was to be once more betrayed, the elements that brought about the betrayal are already reflected in the book, the last of Malraux's revolutionary novels and the last which contains any advocacy of official communism. 


\section{ANDRE MALRAUX: TRAGIC HUMANIST 107}

In Man's Hope the problems involved in the ethics of action are posed in the most acute form to be found in any of Malraux's novels. There is, however, no debate as to whether or not action was justified in order to resist the fascist forces; and although Malraux has broken with the Communists, to this day he refuses to deny or question the validity of the Spanish Republican position. The ethical problems in the novel derive mainly from the nature of the disciplinary measures applied by the Communists within the Loyalist ranks in the name of order, strength, and efficiency. These three items, it will be remembered, were at the heart of Ling's ethical discussions in The Temptation of the West, and they left him with an unresolved dilemma. Nor does Man's Hope offer a solution. The debates on the ethics of action that punctuate the later novel have the same crux as the arguments Ling advances; but they have a more immediate, urgent tone because it has now become an affair of direct application to human beings, not the subject of a philosophic meditation. Franco's armies, supported by German and Italian troops, planes, and tanks, are advancing rapidly. It is necessary to create a force effective enough to oppose them, even if doing so entails injustice toward some neople on the government's side. "The myths by which we live are contradictory; pacifism and the necessity for defense; organization and the Christian myths; efficiency and justice, and so on. We must put them in order, transform our apocalypse into an army, or perish." These words, uttered by Hernandez, who is described as a "very honest man engaged in the war to work towurd the accomplishment of his ethical desires," sum up the situation in which men of good will find themselves.

Even though Man's Hope indicated Malraux's continued acceptance of the Communist Party as the best available instrument for social struggle, the ethics of the Party's activities in Spain are debated to a degree unheard of among the faithful and reflect the author's growing uneasiness concerning the organization's true aims. The extreme gravity of the military situ- 


\section{ANDRE MALRAUX: TRAGIC HUMANIST}

ation nevertheless required quick, effective action, and the Communists appeared most capable of taking it. The reason for Malraux's choice is probably best shown by Garcia's reply when he is asked what he thinks of the Communists. He answers, "They have all the virtues of action, and only those, but that action is what is needed at this time."

It is indicative of the inner struggle between necessity and principle that, in contrast to the provisional endorsement of the Communists, the book also contains lines which the Communists use to try to prove that Malraux has become a Fascist. This is usually done by quoting the following remark by Manuel but omitting, or overlooking, the significance of the final words. "A man who is both active and a pessimist is or will be a Fascist, unless he has a faith behind him." In view of Malraux's career and his belief that nothing will remove the demon from man, it is easy to classify him as both active and a pessimist. Thus, by ignoring the element of faith, extreme leftists claim to have convicted Malraux out of his own mouth. This, of course, completely overlooks the fact that Malraux's work is fundamentally a statement of his faith in the ability of the human spirit to challenge the action of destiny. When another of the characters in Man's Hope says that the "Communists always say their enemies are Fascists," he both forecasts what they would do with Malraux's words and places their treatment of his words in its proper perspective.

The political conflicts that mark Man's Hope are, however, nothing more than dramatic externalizations of the ethical preoccupations common to all his works, intensified by the fact that political reality was making the problem of converting ethical ideals into social reality more acute. Garcia, speaking purely of the Spanish Civil War, presents this in terms that describe all of Malraux's ethical-political activity:

For four months we have all been haunted by cadavers, Scali, all of us, the whole length of the path that leads from ethics to politics. Between every 


\section{ANDRE MALRAUX: TRAGIC HUMANIST 109}

man who acts and the conditions of his action, there is a battle (the action necessary in order to win, not that which will lose what we want to save). It is a problem of fact and of talent, if $I$ can call it that. It is not a subject of discussion.

Ling had an almost abstract interest in this problem as it applied to China; Malraux, and through him the characters of Man's Hope, now had to deal with them on the concrete level.

That situations should arise in which a man is required to violate the dignity of some in order to preserve that of the majority is, for Malraux, part of the tragedy of human existence; and in Man's Hope, he begins to refer to it in terms of tragedy. Not only is he fully aware that violent action, even for the best of ends, has tragic implications, but he also knows that there is no absolute guide in choosing the best of the available paths; it is a negative kind of knowledge that leads to the tragic anguish of choice that is typical, not only of Malraux, but of all those connected with the existentialist position. Garcia, who visualized the revolution as tragic, put his finger on the tragedy of the man who must choose one path while aware of the existence of other paths, each with its own claim to validity:

From the moment that we agree upon the decisive point, de facto resistance, this resistance is an act; it involves you, like every act, like every choice. It bears within itself all its fatalities. In certain cases this choice is a tragic choice. And for the intellectual it is almost always so, particularly for the artist. And afterwards? Ought we not to have resisted?

The major reason for the tragedy implied by ethical-political choices such as revolutionary activity is that Malraux's basic attitudes concerning the relationship of ethics to human destiny had come back to the surface with a vengeance, compounding the outer struggle in which he was engaged with an intense inner one. This was all the more so because death was so often the outcome of these so-called disciplinary actions. For as always, death in 


\section{ANDRE MALRAUX: TRAGIC HUMANIST}

Malraux's philosophy is the final outcome of destiny's action; and the question of whether or not any man has the right to inflict death upon another is of paramount importance. To an even greater extent than Man's Fate, Man's Hope emphasizes the point that suffering and imprisonment, followed by death, is one of the greatest evils a human being can experience, and consequently, that to subject a person to this process is to commit one of the worst of crimes. "What a man can not bear," says Hernandez, "is the idea that after being struck and beaten he will be killed, and that there will be nothing afterward." When, at another point, Hernandez expands on this theme, his words show to what a high degree Malraux's ethical conclusions remain attached to the same basic world vision, a vision to which destiny is ever the key:

The important thing about death is that it makes everything that preceded it irremediable, irremediable forever; torture, rape, followed by death is truly terrible. But the tragedy of death lies in the fact that it transforms life into destiny, that from that moment on nothing can be compensated. And even for an atheist, this is the extreme gravity of the instant of death.

One is inclined to wonder why Malraux used "even for an atheist" here when "particularly for an atheist" would seem to be even more to the point.

It is a dramatic demonstration of the fundamental consistency of Malraux's thought that in the foregoing lines Hernandez, one of the most idealistic of Malraux's heroes, states in general terms what Perken, one of the least idealistic ones, had already put in a personal fashion during his last moments. Like Perken, Hernandez dies in the course of the novel; and also like Perken, he knows his death is inevitable. The two chapters of Man's Hope that deal with Hernandez in prison and awaiting execution include the observations that we have just quoted and duplicate, point by point, the Pascalian image of man's fate. He knows that he is condemned to death, 


\section{ANDRE MALRAUX: TRAGIC HUMANIST 111}

and he is reminded of it each day when fellow prisoners are taken out to be shot by Franco's Moors. "Condemned men think only of death," he concludes in an analysis of the situation that is as tortured as Pascal's own.

Here Malraux's thought parallels that of Dostoevski, also. The Idiot, which one member of the Altenburg colloquia attributes to the Russian's prison experience, contains a passage that, allowing for Dostoevski's difference in religious position, says virtually the same thing as Hernandez:

But the chief and worst pain may not be in the bodily suffering but in one's knowing for certain that in an hour, and then in ten minutes, and then in a half minute, and then now, at this very moment, the soul will leave the body and that one will cease to be a man and that that's bound to happen; the worst part is that it's certain.

There is the sentence, and the whole awful torture lies in the fact that there is certainly no escape. There is no torture in the world more terrible.

"The worst part is that it is certain"-it is the end result of destiny's action. Malraux's word for this sort of situation is "irremediable," and he calls awareness of the irremediable "the most oppressive of all human experiences." Malraux's agnosticism may separate him from Dostoevski and Pascal on the origins and destination of mankind, but all three are in agreement on the crushing effect of a condemnation to death. If anything, Malraux's vision makes it more oppressive; there is no soul to leave the body, no compensation afterward as there is for the two Christian writers. The taking of a human life is, therefore, an act of even greater seriousness for him. On the question of the impossibility of compensation after death, Malraux's thought and terminology closely resemble those of the spiritual father of Existentialism, Martin Heidegger. Heidegger, whose vision of man's forlorn position in the universe was much the same as Malraux's, reaches a very similar conclusion concerning the significance of the moment of death. Life for Heidegger is characterized by the fact that all things are possible; 


\section{ANDRE MALRAUX: TRAGIC HUMANIST}

death, in his terms, by "the impossibility of all possibility." This is the point that Nietzsche calls "the eternal, fatal too late, the melancholia of everything complete."

Where prison itself is concerned, the effects are, according to the characters in Man's Hope, devastating enough, even when they do not end in death. Le Negus says, "Nine times out of ten, when men come out of prison, they can no longer look directly at others; they no longer have a human way of looking." As in Man's Fate, the implication here is that in some way imprisonment deprives men of a part of all of their human quality and cuts them off from any real communion, even with their fellow prisoners. "When I was in prison," Puig states, "I didn't dream there could be so much fraternity."

Neither the problems involved in the taking of life nor any of the other, more fundamental, ethical questions that bedevil its characters reach any kind of a definitive solution in Man's Hope. What does come out of the conflicts in the novel is a greater awareness on the part of the author that to justify violence, one must feel sure that the ends for which it is performed enhance the dignity of man. For Malraux, it was becoming increasingly clear that the Communists were not moving toward the accomplishment of this purpose. Man's Hope contains many sharp criticisms of the ethics of communist actions, criticisms that both forecast the eventual rupture between Malraux and the Communist Party and show the line of reasoning that led to it. Malraux was by now fully aware that his ethical ideal was a dream of human brotherhood that was irreconcilable with the exigencies of political organization. It is symbolic, therefore, that he puts his most bitter denunciations of the Communists in the mouth of Le Negus, who is part of a group, the Anarchists, that likewise has a dream of fraternity that is, in all probability, not completely realizable. Le Negus begins with an attack on Party methods, then, in one of the most frequently quoted passages in the novel, makes a sweeping indictment of its basic conduct: 


\section{ANDRE MALRAUX: TRAGIC HUMANIST 113}

But no more "dialectics"; no more bureaucrats in place of delegates; no army in order to do away with the army; no more inequality in order to do away with inequality; no more deals with the bourgeoisie. Live life like it ought to be lived, beginning right now, or die.

You, you [the Communists] have become curés. I don't say that communism has become a religion, but I do say that the Communists are becoming curés. For you, being a revolutionary means being cunning. It wasn't that at all for Bakunin or Kropotkin. You are swallowed up by the Party. Swallowed up by discipline. Swallowed up by complicity. For any one who is not of yours you no longer have either honesty, or duties, or anything. You are no longer faithful.

More than a decade later, Le Negus' charges will be reiterated when Malraux declares, "No matter how the Communists may try to justify the Hitler-Stalin Pact, it was a betrayal of the western European workers."

The last part of each of these quotations brings us to the heart of the problem; and it is an ethical, not a political, one-the objections being stated in terms of conduct rather than of political doctrine. The accusation "you are no longer faithful," which embodies the crucial issue, is really no different from "Tis the disease of tyranny, no more to take heed of fricndship" hurled by Prometheus at Zeus in a parallel denunciation of an ethical failing. It is also tantamount to saying that with the Party as the instrument of social struggle, it was no longer possible to win without self-betrayal, no longer possible to be loyal to one's own fundamental beliefs. The growing awareness of this made the eventual break inevitable if Malraux was not to violate a very basic tenet of his own ethical position. Although Man's Hope, in such passages as those of Le Negus, implies that the Party's real aims might be very different from its stated ones, the book appeared (1937) before the course of events converted this possibility into a certainty. Hence Malraux's continued, if reserved, support of the Party. With respect to this, it is interesting and cnlightening to compare the foregoing passages 


\section{ANDRE MALRAUX: TRAGIC HUMANIST}

with George Orwell's book on his own Spanish Civil War experience, Homage to Catalonia. Like Malraux, Orwell, who fought in the P.O.U.M. militia, at first believed the Communists' claims that their harsh action was necessary in order to assure victory. His account, which appeared one year after Man's Hope, restates Le Negus' general accusation in terms of specific communist activity. And virtually no one, not even members of the leftist "lunatic fringe," has ever applied the term "fascist" to Orwell. Orwell's words are those of a man of good will who has been disillusioned by the perfidy of those in whom he had once believed:

On the whole I accepted the Communists' viewpoint, which boiled down to saying: We can't talk of the revolution till we've won the war; and not the P.O.U.M. viewpoint, which boiled down to saying: We must go forward or we shall go back. When later on I decided that the P.O.U.M. were right, or at any rate righter than the Communists, it was not altogether on a point of theory. On paper the communist case was a good one; the trouble was that their actual behavior made it difficult to believe that they were acting in good faith. The oft-repeated slogan: "The war first and the revolution afterwards," though devoutly believed by the average P.S.U.C. [Communist] militia-man, who honestly thought that the revolution would continue after the war had been won, was eye wash. The thing for which the Communists were working was not to postpone the Spanish revolution to a more suitable time, but to make sure that it never happened. This became more and more obvious as time went on, as power was twisted more and more out of working-class hands, and more and more revolutionaries of every shade were flung into jail.

What Orwell gives as the P.O.U.M. viewpoint is also the one stated by Le Negus; and one of the ironies of the situation is that, given the demands of the military conflict, it was not workable. Perhaps the real tragedy lies in the fact that those who, reluctantly, consented to see it modified did so at the behest of a political group whose real aims were deeply hidden under apparent service to a worthwhile cause. 


\section{ANDRE MALRAUX: TRAGIC HUMANIST 115}

But what of this conflict as it manifests itself in the action of the novel and in that of the author? Certain salient facts remain true: Man's Hope reflects an event in which a highly dangerous situation did require some sort of disciplinary and organizational procedure; and Malraux himself occupied a position of authority connected with the formation of the Republican air force. It is at once the strength and the weakness of the novel that it does not come to any definitive conclusion in this battle between ethics and politics. It is a strength because an absolute answer either way would be both presumptuous and unrealistic. It is a weakness because not one of the major characters in the book is directly faced with the dilemma in its most acute form; none is required to execute or order the execution of another revolutionary on anything resembling ideological grounds, that is to say, on the basis of loyalty to the Communist Party as such. The leading Communist character is Manuel, a young man as idealistic as was Kyo. Throughout the novel, Manuel undergoes a continuous training for leadership; and part of this training requires him to face the harsh necessity of deciding whether or not to have two of his own men shot-significantly, for an action punishable by death in all armies. After considerable anguish, Manuel orders the execution carried out. Although Manuel is a devoted Communist who never questions the Party's orders, Malraux never puts him in a position where he has to carry out an action for purely communist interests. To underine the fact that Manuel's problems are those of leadership in general and not those of any particular group, Malraux gives the young officer the equally high-minded Catholic, Ximenès, as a mentor. The important non-communist revolutionaries in Man's Hope die as often as not at the hands of the enemy, thus avoiding the problem of having the Party deal with them. The whole treatment of the matter shows a tendency to avoid a head-on collision with a problem admitting of no satisfactory solution, a hesitancy raised to the level of anguish by the absolute necessity for resistance against fascism. On the artistic level, one of the advantages 
of this inner conflict is that it gives, in contrast to other novels on the same subject which see the issues as clear-cut, a feeling of life lived by complex, conscious men involved in the fundamental, unavoidable, and apparently insoluble dilemmas of our time. Man's Hope, according to Marcel Savane, who wrote one of the first books on Malraux, shows, perhaps more than any other novel, what it is to live in the twentieth century.

What we know of Malraux's personal involvement in the Spanish Civil War has much the same quality as the novel. Although his position of authority implied a certain communist approval, it is unlikely, in view of his independent attitude toward Party dogma during the thirties, that he was entrusted with rooting out ideological heresy in the Republican ranks. That there was strain between Malraux and the Party seems indicated by the Party's treatment of his role in the war as that of a mercenary who quit because he was unwilling to accept the discipline of combat-a charge made by Roger Garaudy, whose main mission in life is to see that good Communists stay ideologically pure. Further light is thrown on the picture of Malraux, serving the Spanish cause but aware that something was very wrong in the communist activities, by an incident that Pierre Herbart recounts in his La Ligne de Force. André Gide had just written his Retour de l'U.S.S.R.; but, since Russia was assumed to be aiding the Loyalists, numerous people thought that it might be better to withhold publication of the book, which was a severe criticism of many Soviet practices, until a more opportune time. To resolve the issue, it was decided that Herbart, who was with Gide on his trip to Russia, should take the proofs to Malraux and let him decide upon the advisability of immediate publication, with the understanding that it would not appear until Malraux, who was then at Albacete, Spain, made his decision. Herbart went to Malraux at Albacete, stopping on the way at Barcelona. Contact with Spain convinced him that Russian aid consisted mainly in purging "dissidents," in particular, the Anarchists. When Malraux read the proofs, his main worry was not whether or not it should be 


\section{ANDRE MALRAUX: TRAGIC HUMANIST 117}

published, but whether Gide could be counted upon not to publish it while Herbart was in Spain. If that occurred, the proofs meant almost certain death for Herbart at the hands of communist executioners. Herbart decided to go on to Madrid to consult Koltsov, a Russian who had been involved with Gide's stay in the Soviet Union. While he was there, Gide published his book and the expected furor ensued. Malraux, now aware that Herbart was as good as dead if something were not done, rushed to Madrid, found a pretext for ordering him shipped back to Albacete, and from there spirited him to France. In this action as well as in his novel, we find Malraux trying to work for the Republican cause and at the same time trying to fight injustice perpetrated by a group within its ranks.

The major purpose of this study is not political-the foregoing has been presented because it is relevant to important facets of Malraux's ethics, and because, during this period of his life and works, these are interrelated and interdependent to such a degree as to be inseparable. The reasons for his original acceptance of revolutionary activity as a weapon against man's fate were ethical, as were the reasons for which he ultimately renounced it. The ends toward which the official revolution was moving were not of a high enough order to justify the violation of the basic ethical aspects of his struggle against destiny. To kill and imprison others is difficult to justify even for the best of causes, to do so for one that was becoming increasingly questionable is entirely unacceptable in terms of a vision like Malraux's. The word ethics occurs very rarely in Malraux's earlier works, but it is so frequent in Man's Hope that it sets the tone for the entire novel, pointing up the author's central preoccupation. The path leading to his eventual abandonment of the communist revolution is laid out in a declaration by Scali, a declaration that marks one of the first times that Malraux uses the phrase la mise en question, which has become a key to his humanism. "An attack on the revolution by an intellectual who has been a revolutionary," says Scali, "is always a mise en question of revolutionary politics by 


\section{ANDRE MALRAUX: TRAGIC HUMANIST}

his ethics." In these few words we have the story of Malraux's break with the Party. As employed by the Communists, revolutionary politics did not stand up under a mise en question by his ethics.

In the novel Malraux also emphasizes the ethical element by the creation of a large number of characters who have come to the Spanish war for purely humanitarian reasons, a phenomenon that is not at all uncommon according to Crane Brinton's Anatomy of Revolution. For one of them, the Italian pilot, Sembrano, the internal conflict is so intense that some kind of anodyne is necessary if he is to act. He finds the relief he needs by bombarding from such low altitudes that the danger he is running resolves his ethical problems. Hernandez, as has already been noted, is in the revolution to work toward the accomplishment of an ethical ideal. But perhaps the best example of the idealists, who, Brinton says, flock to all revolutions, is Magnin, who of all the characters in Man's Hope is most frequently associated with Malraux himself. Like his creator, Magnin is French; and also like Malraux, he is an important officer in the air arm of the International Brigades. Although he is not called upon to order the execution of any of his men, Magnin of all the characters in the novel is the one most directly involved with communist disciplinary action. A revolutionary idealist who considers the revolution itself far more important than the Party (of which he is not a member), he discovers that his important service counts for less than Party membership when one of the political commissars tells him, "For me, one Party comrade counts more than all the Magnins and all the Garcias in the world." This same official demands that those who act with the Party do so without reserve, an attitude that Magnin considers "childish." He tries to no avail to argue with the disciplinary extremists. But in so doing, he gives the reasons for his own presence in Spain: "The dream of complete liberty with the power in the hands of the most noble and so forth; all that, in my opinion, is part of why I am here. I want a complete life for every individual, a life that is not qualified by what he demands of 


\section{ANDRE MALRAUX: TRAGIC HUMANIST 119}

others." The importance of these lines can hardly be exaggerated in any study of Malraux's ethics, for what Magnin is really doing is stating the ethical ideal toward which Malraux's humanism is struggling. Should it ever be accomplished, all servitude and humiliation, all infringement on human dignity would disappear; the battle against the internal aspect of destiny would be victorious; and man would be assured a worthy existence within his span on earth. That this is an unrealizable ideal, no one is more aware than Malraux; but like Antoine de Saint-Exupéry, he recognizes the value of "struggling toward a star." On the immediate, human level, Magnin's ideal would require each man to master the demon that is in him.

In spite of the political trappings, the demon is really the basic problem for both Man's Hope and its author. Contributing to Malraux's growing doubts about revolutionary action was another factor, which has nothing to do with the Communist Party as such. This was his continuing feeling that anyone engaging in violence or employing power, even for the best of purposes, is in danger of being corrupted by them. This is evident even in the passages where Le Negus denounces the Communists; for, he says, they have become unfaithful, the implication being that they have not always been so. They have, and in this Le Negus is a good Anarchist, been corrupted by their activities and by the power they wield. As is the case with many of the ethical problems in Man's Hope, this one had already been touched upon in The Temptation of the West; Ling more or less forecast what would happen to the Party in this respect. It should not be assumed from this, however, that in Man's Hope the threat of deterioration is discussed only with reference to the Communists or even strictly with respect to violence and power. Puig, picking one of the things about China that bothered Ling, asserts, "When one forces a people to live basely, such action does not lead them to think on a high plane. You don't teach people who have received nothing but blows for two thousand years to turn the other cheek." Like his Chinese counterpart, Puig is thinking of an eruption 


\section{ANDRE MALRAUX: TRAGIC HUMANIST}

of popular violence by masses who have known only unjust oppression when he states, "Vengeance against the atrocious drives the masses as mad as it does individual men." 1

The concept of deterioration through too much contact with violence occurs in still another statement in Man's Hope: "One of the things that troubles me most," says Garcia, "is to see to what a degree, in every war, every one absorbs from the enemy, whether he wants to or not." Since Garcia is an independent leftist engaged in a war against Franco, it may be assumed that he is not talking of the enemies' desirable attributes.

It appears, therefore, that the menace is ever present and multifaceted. By wielding power or force oneself; by being the victim of them in the hands of others; or even by simply being in contact with them-by all these paths men, according to Malraux, run the risk of degeneration. All of them are only aspects of the central core of danger, that of the demon in man; for all of them, in one way or another, tend to make man complacent about the destructive action of his internal flaw. Malraux sums all this up when he writes of Garcia, "He knew that you must not tempt the beast in man." In Man's Hope, the human potentiality for destruction is also referred to as the demon. In a line that once again shows the author's awareness that he is on some common ground with religion, Lopez declares, "The cathedrals fought for all and along with all against the demon, who, moreover, looks like Franco." "Christ," says Puig, "was an Anarchist who succeeded."

${ }^{1}$ Two things in particular stand out in these echos from The Temptation of the West heard in Man's Hope: more often than not, they are put in the mouths of Anarchists, and they are, in general, consistent with anarchist ideas. All of which leads to an interesting conjecture. How early did Malraux come into contact with works such as those of Kropotkin and Bakunin, both of whom are mentioned in Man's Hope, and how much of them did he absorb? A liberal early dose of anarchist theory could partially account for the rather independent attitude that both Malraux and some of his communist heroes maintain toward the Party and its dogma. 


\section{ANDRE MALRAUX: TRAGIC HUMANIST 121}

Man's Hope also picks up and further develops Ling's idea that civilization is a matter of individual feelings and not social or political order. Malraux's growing disillusionment with the instruments available for improving the lot of the world's oppressed was forcing him to reject action designed to alter political structures, and to consider the problem increasingly as a matter of improvement in individual human beings. The elder Alvear declares "that if each person would apply to himself one-third of the effort he was applying to the form of government, it would become possible to live in Spain." Ximenès, in dealing with the same proposition, expands it to a general observation on mankind by employing a formula that is dear to Malraux himself, "The real combat begins when one must fight a part of himself Until then, it is too easy. But one becomes a man only by such combats. We must always encounter the world within ourselves, whether we like it or not." Years later, in both his unEsco speech and in The Voices of Silence, Malraux will claim that "man becomes man only by the pursuit of the highest that is in him." If it were only Alvear, an old man, and Ximenès, who shows no real interest in the form of society, who take this position withdrawn from society, it could be objected that it is the opinion of men with no consuming desire for social reform. However, the fact that this attitude does not preclude effort for such reform is illustrated by Garcia, who is actively furthering the revolution, but who, nevertheless, asserts that "moral improvement and nobility are individual problems in which the revolution is far from being directly involved." Elsewhere he makes this more general and more categorical when he declares, "No state, no social structure, creates either nobility of character or spiritual quality." However, this is not meant to imply an attitude that, by itself, would be rankest reaction and the direct negation of Malraux's attitude in the social struggle. Rather obviously, the oppressed masses whose possible future action worries both Garcia and Puig would be less of a problem if the society in which they live had conditioned them less to suffering and injustice and more to 


\section{ANDRE MALRAUX: TRAGIC HUMANIST}

dignity and justice. Garcia makes it clear that one can believe that the struggle with the demon is basically an individual affair and still struggle toward a society that will give each man a better chance of winning when he appends to the foregoing remark, "At the very most we can move toward more propitious conditions, and that is a lot."

Also reflected in Man's Hope is Malraux's concern, first manifested in The Temptation of the West, with the relationship of the individual to the political order. As indicated by what is said in Man's Hope, his position remains unchanged; he has Le Yiegus convert Ling's personal attitude toward this relationship into the general declaration that "parties are made for men, not the men for the parties. We do not want to make a state, or a church, or an army; we want to make men." Ling's compatriot, Souen, had said the same thing in Man's Fate. Thus we find both Chinese and Spanish revolutionists echoing Ling's stand that the purpose of any social or political structure is to serve the individuals of which it is composed. All resist the totalitarian ideal in which man exists only to serve the state. Does this represent Malraux's own position? In a political speech delivered in 1948, he asserted, "The guarantee of liberty is the strength of the state at the service of all its citizens." The anarchistic position of Le Negus, Puig, and Souen is too extreme for Malraux, who feels strongly the need for a functioning government. The problem of the relationship of the individual to the society is too complex to be treated here in detail. In the final analysis, though, Malraux intends the state to serve the man and not to add more humiliation and servitude to the already heavy burden of destiny.

The matter of humiliation leads directly to the question of its relationship to fraternity. Employing exactly the same formula that Kyo used when he defined dignity as the contrary of humiliation, Barca declares, "The contrary of humiliation is fraternity." What these words do, essentially, is to carry one stage further a long process of synthesis in Malraux's thought, a process that has sought to make fraternity, already the equiva- 


\section{ANDRE MALRAUX: TRAGIC HUMANIST 123}

lent of the heroic sense, synonymous with human dignity. The idea is a complex and difficult one, by no means completely formed even today. The equation of fraternity with the heroic sense is relatively simple since both predicate an idea of human unity, particularly against humiliation. Generally speaking, the idea seems to be that a man, free of humiliation, in possession of his own dignity and valuing that of others is by that very fact endowed with fraternity or the heroic sense, whichever term one chooses to use. And conversely, fraternity would be the essence of human dignity. It is here that the French word conscience, so often employed by Malraux, particularly in recent years, comes in to unify the terms under discussion. For conscience, the source of man's dignity, translates into English both as "consciousness" or "awareness" and as "conscience." The double meaning of the word, more apparent than real, carries the implication that genuine awareness also includes conscience. Since the relationship of conscicnce to the heroic sense and fraternity is obvious, and since conscience also includes that which is the origin of human dignity, it seems clear that MIalraux has used the term because it unifies the most important elements of his ethical thought.

Here we are dealing-and this is increasingly typical of Malraux-less with the external manifestations of the struggle with the demon than with its inner source, human nature itself. And one of the things modified by this shift of emphasis is fraternity. It still remains essentially a virile fraternity in that there is still a common struggle against destiny; but less importance is given to the precise form that this struggle takes, to the nccessity for sharing common political or social views, and more to a communion of fundamental attitudes. "I want," says the elder Alvear, "to have relations with a man because of his nature, and not because of his ideas. I want fidelity in friendship, and not friendship that is dependent on a political attitude. I want a man to be responsible to himself-and you know, M. Scali, that this is the most difficult, no matter what one says-and not to a cause, 


\section{ANDRE MALRAUX: TRAGIC HUMANIST}

even that of the oppressed." Or as still another character puts it, "Friendship is not being with a man when he is right, but being with him even when he is wrong." Once again the "human bond" of The Royal Way.

Also deep in human nature is another element that struggles against the demon, according to Malraux. Equally as irradicable as man's capacity for cruelty is a deep-seated hope, the hope that gives the novel its title-the hope that, in spite of all the odds and all the suffering, there is the possibility of a worthy existence. This ineradicable hope that an unjust situation can be modified is an important factor in maintaining the battle against destiny. "He who has been condemned unjustly, who has too often encountered stupidity, ingratitude, or cowardice, feels very strongly the need to turn to some new ideal." Here, perhaps, is the inner drama of Malraux's abandonment of revolutionary action.

Here, too, we again rejoin Nietzsche; for this "profound and terrible hope" is not essentially different from the "profound Aeschylean yearning for justice" that the German philosopher sees as the keynote of Prometheus Bound. When, like the Titan, one is fully aware, that is to say, possessed of conscience in both senses of the term, this yearning for justice becomes a desire that, not just one individual, but all mankind enjoy it. Malraux's ethic is still that of Prometheus fighting against the chains to which Zeus had condemned him, a penalty he is suffering because of his fraternal attitude toward humanity. That far more can be gained in the effort to give man dignity if the hope is a fraternal one is indicated when Alvear continues his thought by adding, "Men united by both action and hope, like men united by love, can attain things that they could never attain alone." The first words of Alvear's statement reflect both the outer and the inner aspects of Malraux's ethical vision, containing as they do action, representative of the former, along with hope and love, which come from within.

The increasing move away from the emphasis on action toward a more inward aspect of the struggle with the demon is given further impetus by 


\section{ANDRE MALRAUX: TRAGIC HUMANIST 125}

Malraux's growing worry about the nature of action itself, a fact that intensifies still more the ethical anguish that characterizes Man's Hope. This is the awareness that all action is a two-edged sword capable of evil as well as good. "The means of action," says Garcia, summing up the question, "are Manichean, because all action is Manichean." Magnin, who, because of his command position, finds himself confronted with concrete examples of this dual nature of action, is thereby led to reflect that "action is action and not justice. And he hadn't come to Spain for injustice." It takes little or no imagination to see that when conscience, to which Malraux gives such weight, is brought to bear on this Manichean quality of all action, it imposes a tremendous moral burden on anyone who elects to take strong action, even for the betterment of mankind. Although the action is performed in order to increase human fraternity, the one who acts must be fully aware that in so doing he will also violate this same fraternity. "You wish to act without losing anything of fraternity," Ximenès tells Manuel. "I think that man is too small for that." It would not be too much of an exaggeration to say that the real tragedy of Man's Hope is inherent in Ximenès' words, and, by extension, they also imply the dilemma that led to Malraux's abandonment of revolutionary action-the action necessary to attain fraternity may also, and at the same time, destroy it. And here again we have a remarkable parallel between Malraux's path and the one he attributes to T. E. Lawrence in "N'Etait-ce done que cela?" Malraux declares that "what in fact had separated him [Lawrence] from the revolt was the very thing that he had wanted to express in his book, to be the source of its greatness: All human action is corrupt by its very nature."

Malraux's position has evolved to a point where he sees in fraternity, with its attendant implications, the finest possible answer to the anguish, humiliation, and isolation of man's fate. At the same time, he has become acutely conscious that the struggle to attain the widest possible extension of fraternity exacts its own price in anguish. For this tragedy of action is 


\section{ANDRE MALRAUX: TRAGIC HUMANIST}

a far more fundamental one than that of the conflict between ethics and politics discussed earlier. Its problem lies, not in the corruption of the instruments for social action, but in the nature of action itself. There are causes, such as the defense of France against the Germans, whose purity Malraux does not question and for which he has taken direct action. Even this, however, does not efface the awareness that action performed in behalf of such causes is still dualistic in nature. This inherent and unavoidable tragedy is reflected in the faces of those being called upon to defend worthwhile causes while under the burden of this awareness. Malraux has written that the best-known pictures of himself all make him look like a "sad type." And Ximenès asks Manuel, "Have you ever looked at the faces or the portraits of men who have defended the finest causes? They should be joyous, or at least serene. Their first expression is always sadness." The stage is fully set for the abandonment of revolutionary action; and with Man's Hope Malraux's cycle of "revolutionary novels" is closed.

With The Walnut Trees of Altenburg the inward direction of the ethical struggle is still further accentuated. By the time the novel appeared, Malraux's break with the Communist Party and with revolutionary activity was complete. It was inevitable that this would be reflected in a work that attempts to assess the experiences of the author's life. However, in tune with the book's more contemplative tone, he avoids direct recrimination while tracing the process of his alienation. The whole thing is done by illustration; the word communist is never mentioned. Vincent Berger, the father, who is a symbol for the Malraux of the revolutionary years, has been traveling about the Near and Middle East on behalf of a Pan-Turkish movement called Touran, which is to be essentially a brotherhood of countries centered in Turkey. A series of disillusioning experiences, culminating in a violent attack on Berger while he is in Afghanistan, force him to recognize that the brotherhood toward which he is working does not exist. An ironic noted is added when Berger strongly suspects that he was attacked 


\section{ANDRE MALRAUX: TRAGIC HUMANIST 127}

because he himself was not a Turk. Throughout the entire Touran affair, he had been wearing a Moslem beard to make himself appear one with the people among whom he was moving; this he now shaves off. When one is familiar with Malraux's life, it takes little imagination to see in this a fictional presentation of his relationship to the Party-never fully a part, but working with it toward what he thought was a common goal. Substitute world communism for Touran, the Soviet Union for Turkey, and the following lines tell the story of Malraux's disillusionment:

The existence of Touran had been so evident to him that he had never really questioned it; in the same way that, before Luther, innumerable Christians had come to Rome without seeing the simony; in the same way that French anglophiles of the eighteenth century returned from London without seeing the brutally evident power of the aristocracy. This was the way he had grasped, retained, and related facts, only in relation to the myth of Touran. A man does not see any more accurately a country that embodies a myth in which he believes than he sees a woman he loves.

The hypothesis that this is actually Malraux talking about the death of his dream of social rectification through communism and Russia is strengthened by the close similarity of the passage to remarks later made in the Postface to the definitive edition of The Conquerors. There he speaks of the agony caused by the political myth of the Internationale and adds, "What we have learned is that the great gesture of disdain with which Russia brushes aside the song of the Internationale, which, whether she wishes it or not, will remain linked to her in man's eternal dream of justice, sweeps away in a single stroke the dreams of the nineteenth century." Both passages describe the same awakening.

The Walnut Trees of Altenburg is, however, less directly concerned with the social struggle as such than anything Malraux had written since The Royal Way. This does not mean that the fundamental ethical themes are 


\section{ANDRE MALRAUX: TRAGIC HUMANIST}

lacking, but rather that they are discussed in a meditative tone and on a philosophic level instead of in terms of direct application, as they are in Man's Hope. A prime illustration of this difference is in the handling of the idea that imprisonment and humiliation destroy fraternity and isolate the victim, even after release. In contrast to the captivities and executions that marked the earlier book, the intellectuals gathered at Altenburg discuss isolation in relation to three books. Significantly, in view of the fact that Malraux was soon to begin publishing his essays on art, they speak of the link between isolation and artistic creation. All begins when one of the participants at the colloquia suggests the three best books to take if one were condemned to prison. Thirard's choices are The Idiot, Don Quixote, and Robinson Crusoe; ${ }^{2}$ his explanation of this selection is so typical of Malraux's literary interpretation and so indicative of his position on the vital relationship between humiliation and isolation that it merits quotation at length:

"But note well, they are the same book, the very same. In the three cases . we are given a man who is, at first, separated from the rest of mankind; Robinson by shipwreck, Don Quixote by madness, Prince Myshkin by his own nature let us say, by his innocence. The three great solitaries of the world novel. And what are these three stories? They are the confrontation of each of these solitaries with life; the story of his fight to destroy his solitude, to find mankind again. The first fights by work, the second by dream, the third by saintliness. I am a little rapid at the moment, a simple bird's-eye view! I know, I know (he imitated an imaginary contradictor and shrugged his shoulders hurriedly), Daniel Defoe was not shipwrecked, Cervantes was not mad, Dostoevski was not a saint!

"As if humanity were lacking in desert islands, as if we didn't have them

${ }^{2}$ This selection was by no means a matter of chance nor was it original with Malraux. In a speech published in Commune (September, 1936), he tells of being visited by an ex-prisoner who told him that one could stand only these books in prison. Malraux's analysis of the reasons for the choice are the same as Thirard's. 


\section{ANDRE MALRAUX: TRAGIC HUMANIST 129}

on every corner! The streets are paved with desert islands. And there is everywhere a decisive means of being cut off from the community of men: it is humiliation, shame.

"And note well that the three great novels of the reconquest of the world were written, one by a former slave, Cervantes; the other by a former prisoner, Dostoevski; the third by a man who had been condemned to the pillory, Daniel Defoe."

Malraux's belief that humiliation, which reduces man to isolation, is the deadliest enemy of fraternity is so clearly delineated here that further explanation seems superfluous. "Art thou a slave?" wrote Nitezsche in his Zarathustra. "Then thou canst not be a friend." Cervantes' slavery, in particular, seems to haunt Malraux; for it recurs in Saturn, which is devoted to another great Spaniard, Goya. In evoking the horror of the night depicted in the latter's "The Third of May, 1808: Execution of Rebels," Malraux lists a series of real and fictional horrible nights, concluding with, "It was on such a night that Cervantes learned he was a slave." The relationship of this to Malraux's own prison experience and to the prison of man's fate is quite clear. Significant, too, is the fact that the movement from isolation to the rediscovery of humanity to fraternity, described in Thirard's explanation, parallels the course of Malraux's own novels from The Conquerors to The Walnut Trees of Altenburg.

There is, perhaps, in Malraux's works no better example of fraternity in action against the demon than the scene of the gas attack in The Walnut Trees. The Germans have employed a new and deadly poison gas in an attack against the Russians on the eastern front. It is highly effective and the German troops advance into the trenches of the Russians, who are helpless and dying, their bodies hideously decayed by the action of the gas. The German soldiers are, to the anger of their leaders, horrified at the effects of the gas on the Russians. Their reaction is immediate; the German soldiers try to carry the Russians out of the infected area. "In this whole 


\section{ANDRE MALRAUX: TRAGIC HUMANIST}

movement," writes Malraux, "in the way in which the German held the body, there was a clumsy and poignant fraternity." Here there is no question of common social or political aims, but an expression of that inner force in man that fights against the demon inside. This fraternal action is a result of conscience, of a simultaneous awareness that the so-called enemies are also fellow human beings and that there is something inherently wrong in such destruction of human life, an awareness whose nature is expressed in the protest of a German soldier: "No, man is not made in order to be reduced to rot [moisi]." Although this spontaneous rescue is indicative of Malraux's recent increased interest in man's nobler inner drives, it is not without precedent in his earlier novels. During the seizure of Shanghai, Tchen finds himself separated by a small but bullet-swept open space from a government soldier, bound and with one leg blown off, screaming in terror because the building in which he is trapped is rapidly burning. Tchen feels an overwhelming desire to free the prisoner; and, in spite of his intense fear of being wounded, Tchen, who killed one man in the opening pages of the novel, risks his life to save a wounded enemy. His motivation was the same deep feeling of human unity that led the German soldiers to perform a similar action. "He was himself that bound man."

This is already Malraux's "consciousness of what it is to be a man," although he has not yet employed the phrase; implicit in the exclamations of the horrified Germans is the idea that the attack is a violation of human dignity, and that dignity has nothing to do with national, racial, or social lines. "I say that a man has dignity everywhere," notes one of the soldiers, "or he has it nowhere." The concept of dignity, so vital to Malraux's humanism, is thereby placed on a universal basis. The soldiers who make these key remarks in The Walnut Trees of Altenburg are simple peoplepeasants, manual laborers, and the like. This represents a significant and, I believe, symbolic change from the combatants of his earlier works, practically all of whom were intellectual and articulate. In a sense, the truth, 


\section{ANDRE MALRAUX: TRAGIC HUMANIST 131}

as Malraux sees it, is taken out of the mouths of the leaders and theorists and put into the mouths of those whose contact with life is simple and direct. For reasons that will be discussed later, this should by no means be taken to imply an anti-intellectualism on Malraux's part. Suffice it to say here that by using simple people, people common to all the countries of the world, he has underlined the fact that conscience is internal and the capacity for it universal.

Universal though this capacity may be, it is not per se a guarantee against the action of the beast. Like any of man's other facultics, it can be strengthened, or weakened to the point of impotency. With respect to the negative aspect, the reduction of conscience, the problem is none other than that introduced by Ling and continued throughout Malraux's worksviolence corrupts. Vincent Berger is heartened by the action of the Cierman soldiers but is also aware of the sober fact that "the dam of pity would not be effective many times. Dying is the only thing that man does not become accustomed to." The image of the dam is carefully chosen: a dam under the pressure of too much water will eventually burst, releasing a destructive flood of water. In a similar fashion, conscience under the pressure of too much contact with violence will give way and allow the human potentiality for cruelty to take over. This symbol of man's inner power is also indicative of the direction in which the ethical aspect of Malraux's humanism is heading. An obvious way to reduce the danger of flood is to strengthen the dam.

It is precisely the demon that is being held back by the mutinous action of the German soldiers. In describing the atmosphere of this particular scene, Malraux writes that in all probability believers would call such a thing a "visitation of the demon," and adds that "the spirit of evil" was even more present than death itself. For Malraux there is no question of the demon's being a supernatural or outside force; it is within man himself. As one of the Altenburg participants observes, "We must know man in order to 


\section{ANDRE MALRAUX: TRAGIC HUMANIST}

recognize the ways of the demon." Knowledge of man-of inner man-has been the goal of the greater part of Malraux's effort in the last two decades. One possible path to this knowledge is psychology; and although it may not be precisely accurate, the title The Psychology of Art is not a random choice. Psychology, along with religion, is applied to the problem of the demon in The Walnut Trees of Altenburg. In Vincent Berger's opinion:

All psychology is the search for an interior fatality. Christianity's coup d'état was in having installed fatality in man himself, in having based it on our own nature. A Greek was concerned with his heroes historically when he was concerned with them at all. He externalized his demons in the form of myths, and the Christian internalizes his myths in the form of demons. Original sin concerns everyone. The crucifixion concerns everyone.

In reply to an objection, Berger states that he is aware that in certain Greek tragic heroes the demon was an internal one, but that they were individual demons; whereas, Christianity makes the presence of the demon universal-a point with which Malraux would wholeheartedly agree even while disagreeing with Christianity on the origin of the demon. Wherever the demon may have come from, it is, for both Malraux and Christianity, within man.

Through all this Malraux continues to seek answers to his questions on the nature of the demon in man and its relationship to conscience and the creative drive-in short, to move toward an answer to the basic question of The Walnut Trees of Altenburg: "What is man?" Malraux is by no means presumptuous enough to claim to have found an answer to the question; as a true part of his humanism, it remains a continuing interrogation. In this process The Walnut Trees is a genuine transitional work; it represents the completion of the movement from an external to an internal emphasis on methods of dealing with the demon-a shift from trying to fight the demon 


\section{ANDRE MALRAUX: TRAGIC HUMANIST 133}

by political action to an attempt to fight it by grasping its nature and strengthening internal bulwarks against it. The book synthesizes all these factors. Nowhere is this better illustrated than in Malraux's choice of a title for the series of which the novel was to have been a part: La Lutte avec l'ange ("The Struggle with the Angel"). It is drawn from Jacob's struggle with the angel in Genesis, a struggle characterized by a lack of clarity as to whether Jacob is battling against God, Satan, his own guardian angel, or Esau's evil one. This inextricable comingling of that which is good and creative with that which is evil and destructive symbolizes, not only the novel itself, but Malraux's further treatment of the problem of man's dualism. The series of novels has not been continued, but the books on art are a logical extension.

From the discussions concerning the demon in The Walnut Trees of Altenburg, it is but a step to Malraux's definition of the demon in Saturn as "everything in man that aspires to destroy him." It is typical of the ethical unity of Malraux's work that this definition should appear in a book devoted to the analysis of an artist. This, too, is the work in which he first refers to the human condition as a prison. "The metaphysical absurdity is intact," he writes, centering attention on the starting point of the whole struggle. And rarely has Malraux's position on the cosmos and man's capacity for humiliating his fellows been shown more directly than when he writes, "It was to metaphysical death, and first of all to its peremptory expression, cruelty, that Goya intended to reply." One form taken by Goya's reply is the picture from which the book takes its title; it depicts a giant devouring a man, a plastic and vivid delineation of the demon in man. That such was Goya's intention as Malraux sees it is shown when Malraux adds after his definition of the demon, "That was the demon that fascinated Goya." In describing the process of Goya's artistic creation, Malraux shows that the anguish caused by the demon is the source of such ghastly pictures as Saturn: "Henceforth, the demons had found their true 


\section{ANDRE MALRAUX: TRAGIC HUMANIST}

form: the atrocious. Ever since his illness Goya had been looking for those demons that the common human anguish recognizes at first glance: humiliation, nightmare, rape, prison." These elements occur both in Goya's etchings and in Malraux's novels. Humiliation has been discussed to such a degree that there is no point in further mention of it. Not only is there the nightmare quality of such scenes as that of the prison episode in Man's Fate, but Tchen so suffers from nightmares, mainly of octopi, that he is afraid to go to sleep. It would seem that for Malraux nightmares are, in a sense, tortures inflicted on the individual by his demon. Although he never bothers to analyze nightmares, Malraux's inclusion of them among the things that cause human anguish is an interesting parallel with Freudian dream significance, particularly in view of his increasingly inward, and in a sense psychological, approach to the demon. Tchen's nightmares, like the creatures of Goya's etchings, take hideous and symbolic animal forms generally associated with horror and destruction. The Conquerors provides an example of homosexual rape when Garine recounts the incident of the so-called republican marriage. Imprisonment, "the outrage and ignominy of bondage" denounced by Prometheus, is, as it always has been for Malraux, one of the worst of all forms of suffering. In addition to the reference to Cervantes' slavery, Malraux writes of Goya that one of his series of etchings has a "prison-type unity, a feeling of dependence."

As already recorded, Malraux sees in Goya's attitude toward the monks who comfort the mon in prison a close parallel to Hong's and Tchen's denunciation of the Christian tendency to accept suffering. However, where the monks are concerned, Malraux manages to convey the idea that the criticism is less of the true Christian ideal than of some of the unworthy forms it has taken in official religion. Along with calling these monks "hope peddlers" and saying that Goya hated them, Malraux refers to them as "impostors in the name of Christ." This softened attitude does not in any way indicate that Malraux has reached the point where he is prepared to 


\section{ANDRE MALRAUX: TRAGIC HUMANIST 135}

accept a theological justification, Christian or otherwise, for the acceptance of suffering. To the contrary, it is in The Voices of Silence, which followed Saturn, that he cites Ivan Karamazov's story of the tortured child. It is this same child that he has in mind when he writes of Goya, "His genius sprang from the dialogue that has continued since the Sumerian chants between the closed mouth of a tortured child and the millennial, invincible, and perhaps inexorable face of God." Malraux's ethic continues to rejcet any acceptance of the demon's action and to base the demon himself in human nature.

Saturn pursues, on a symbolic level, the idea that in human nature also lies the weapon against the demon. In the final pages there are two colossal human figures: one, a giant, "whose anxious face dreams amid the stars"; the other, in the words of the title "a sleeping colossus," a noble human face held, Gulliver-like, to the ground on which it is resting by innumerable small figures. Clearly, these colossi are intended to represent man's inner potentialities for greatness and nobility, which he says "make Goya's work fruitful."

Clearly, too, this indicates an ever closer interrelationship between the ethical and the artistic aspects of the struggle with destiny-man's creative urge, as exemplified by art, being a major form of reply to his destructive impulses. Malraux's treatment of Goya's Disasters of War, which deal with the French invasion of Spain, provides an interesting example of this interrelationship and of a parallel that Malraux sees between the great Spaniard and himself. Goya was a liberal who saw in the ideas of the French Revolution a possibility for regenerating Spain. "The Disasters," Malraux writes, "acquire their full meaning when one knows that they are not only the work of a bitter patriot but of a disillusioned friend. The album of a Communist after occupation of his country by Russian troops." It was perhaps inevitable that at this stage of transition from novels almost purely ethical in basis to the major books on art, Malraux should have 
136 ANDRE MALRAUX: TRAGIC HUMANIST

chosen to analyze this artist, who, like himself, was so preoccupied with man's inhumanity to man.

Although The Voices of Silence deals primarily with art, it is actually a synthesis of all Malraux's philosophy and as such is an outstanding demonstration of the extremely high degree to which all its aspects are united. In part this is shown by the number of times that we have turned to it for elucidation and crystallization of ethical problems in the novels, such as the choice of true values over satiation, the rejection of suffering, and many others. To re-analyze or even recapitulate them here would be both boring and unnecessary. A second indication of this synthesis is Malraux's increasing use of the term conscience, bringing together the various elements of his ethical answer to the demon and with this, centering them in human nature, bringing them closer to the source of the creative urge within man and not in some transcendental area. The Voices of Silence, it will be remembered, is the work in which Malraux refers to Greek tragedy as "the intrusion of the world of conscience into that of destiny." The evolution of his thought makes it increasingly evident that this best describes both the ethical and the artistic aspects of his humanism. The close intertwining of the two in The Voices of Silence is shown by his use, in an art context, of key words from his novels. He writes of art that, for the humble, is "fraternal," as contrasted to art that they find "humiliating." In another interesting passage, he describes an artistic change and a social one in parallel terms: "The accusation of the social condition leads to the destruction of the system upon which it is founded. The accusation of the human condition, in art, leads to the destruction of the forms that accept it." The fusion is still more complete when Malraux assigns to art a role in awakening Western man to the tragic realities of his current precarious situation, a situation due precisely to the demon:

History-the history that obsesses Europe today as the interrogation of Buddha ravaged Asia-was born. No longer a chronology but an anxious 


\section{ANDRE MALRAUX: TRAGIC HUMANIST 137}

interrogation of the past to try to discover the destiny of the world. Western civilization began to question its own continued existence [se mettre en question]. From war, a major demon, to the complexes, minor demons, the demoniac element, more or less present in all barbaric art, reappeared on the scene.

Malraux follows this passage by repeating the definition of the demon that he had given in Saturn. Another time he speaks of the demon of Bikini and the demon of Freud. References to complexes and the father of psychoanalysis serve to illuminate once more the increasingly inward focus of Malraux's ethical effort.

What is perhaps most noteworthy in this passage is the idea that the power of the demon, or his weapons, has reached a point where no affirmation of the continuity of man is possible, and the human race must se mettre en question. This is a stronger statement than any made in his novels. The history that they reflect contains an ethical struggle sometimes agonizing in its intensity but without any threat of complete extermination. Later history has made Malraux, as it has so many millions of others, feel that we must move forward in the ethical struggle or perish. Thus, rather than indicating a decline in Malraux's awareness of the ethical problem, The Voices of Silence finds it more acute and urgent than ever.

To move forward in this struggle still means, for Malraux, to move toward greater human unity. The Voices of Silence carries on the tendency, already present in the novels, to deepen and broaden the idea of fraternity. One result of this has been a partial substitution of the word communion, implying a more deeply seated, fundamental feeling, for fraternity. In a passage that evokes Alvear's remarks in Man's Hope, he indicates that from communion itself can come further desirable results:

Thousands of human beings can be united by faith or by hope for a revolution; but (except in the language of propagandists) they are not the masses, they are fellow men, often united by action, always by that which, as they 


\section{ANDRE MALRAUX: TRAGIC HUMANIST}

see it, counts more than they do. Every collective virtue is born of a communion [italics Malraux's].

Malraux will continue to hammer on the idea contained here that man is at his best only when orienting himself on something that is more important than he, something which, while not necessarily divine, is above and beyond man. Here, as in the matter of communion, Malraux is on common ground, and consciously so, with the best that is in religion. "The art of living religion," he declares, "is not that of an assurance against death, but of a defense against destiny through an immense communion." These are virtually the words that Gisors used in pointing out the significance of Man's Fate at the end of the theatrical version. But no less significant are Gisors' additional words: "If God is dead, nothing is changed." For Malraux, a man struggling for a better, happier humanity is oriented toward something above and beyond, something more important than himself, just as much as if he is oriented toward the godhead of some particular religion. Given the present state of society, a vision of humanity living together in universal dignity and brotherhood constitutes a transcendent ideal. For this reason, such statements as Joseph Gannon's to the effect that in the final analysis Malraux fails because he lacks a transcendent ideal hardly seem valid. This is a criticism derived from formal religion, and it is perhaps best refuted by stating that Malraux's idea of communion is not the one he sees and appreciates in the great religions, which he regards as too limited. As he observed in his article for Dagens Nyhiter, religions generally make fellow men only of their co-religionists. "But," he writes in The Voices of Silence, "Christ came to save all men." (The italics are Malraux's.) Here again he differs, not so much from the Christian ideal, as with the interpretations that have been given it by the various sects. Speaking, not specifically of his own humanism but of what he feels is a widespread contemporary effort to grasp and understand man's creative 


\section{ANDRE MALRAUX: TRAGIC HUMANIST 139}

power, not in terms of any religion, but in terms of man himself, Malraux advances the possibility that time may reveal that no other approach to man "tried so hard to bring to all men their own grandeur." And the great movement toward an ever widening communion in no way either reverses or even contradicts Malraux's more inward approach to the problem of the demon; for first of all we must still begin within ourselves our movement toward unity with other men.

Malraux's minor writings, scattered throughout the decade in which he wrote the art books, confirm both his continuing preoccupation with ethics and his search within man for problems that his demon presents. A speech delivered in 1948, and later used as the Postface for the definitive edition of The Conquerors finds him attacking a means of constraint that would have gladdened the heart of Ferral had he known of it: psychological conditioning, or, to use the currently popular term, "motivational research." He compares the United States and the Soviet Union with respect to this technique, pointing out that while the former employs conditioning only to constrain people to buy, the latter uses it to control their entire way of life. Malraux's analysis of the eroticism in Lady Chatterley's Lover and the Les Liaisons dangereuses, both of which precede this specch by several years, already show him to be aware of the method of making people do what one wants by finding and using the right psychological lever. Thus, almost a decade before "motivational research" became a catchword, and before its morality was questioned by books like The Hidden Persuaders, Malraux was already denouncing the use of people as a means to an end, and not a very worthy end at that.

In the main, the articles and speeches of these years tend to confirm the hypothesis that such characters as Kyo, Gisors, Hernandez, Garcia, and others speak very directly for the author. A brief article entitled "Culture," written for Liberté de l'esprit in 1949, has much the same tone as Man's Hope, which appeared ten years earlier. Malraux challenges the complete 


\section{ANDRE MALRAUX: TRAGIC HUMANIST}

lack of honesty and the malicious distortion with which communist writing treats France. If it is again Le Negus who is speaking in this denunciation, it is Garcia who is heard again when Malraux writes that he knows that "all political action is Manichean." The ethical-political debates that punctuated the novel are focused in the question: "I wonder if in justifying an ethic by its ends we do not risk making a humanity that is as detestable as an art that is justified by its subject." His concept of an ideal world in which everyone would know dignity is reflected when he quotes Nietzsche as having written, "Perhaps the most important thing is to spare every man shame.' Malraux then goes on to wonder if there is not in humanity, as soon as it begins to form into civilizations, a preoccupation with grandeur that is mysteriously fraternal. A glance suffices to show that most of these ideas are phrased as questions; for the ethical part, like all the other parts, of Malraux's humanism remains essentially an interrogation of man and his potentialities.

It is significant that this short article, largely ethical in content, should be called "Culture," for it indicates both the continuing synthesis of Malraux's thought as well as that for him culture is by no means synonymous with refinement or anything similar. The closing lines define it as the will to discover, inherit, and augment all that makes up the nobility of the world. A few years later at a meeting for cultural freedom, he repeated the same definition, then pushed it one stage further to state, "Culture is the ensemble of everything that makes man less a slave and more free." That this is a logical answer to the prison of the human condition is obvious. Three times in the course of his speech Malraux associated this ideal with Prometheus.

Although The Metamorphosis of the Gods is anything but a minor work, I have chosen to deal with it here because it deals with ethics per se far less than do any of Malraux's other major books. He does, however, in it refer to virile fraternity; and when he speaks of art as being part of everything 


\section{ANDRE MALRAUX: TRAGIC HUMANIST 141}

"that helps man triumph over instincts, chaos, animality, the eternal Siva," he shows that the ethical preoccupation is still central. "Olympia," Malraux writes, "required of man that he master himself."

And, in a sense, The Metamorphosis of the Gods indicates the present stage of development in Malraux's ethical thought, upon which further light is thrown by his article in the Dagens Nyhiter, which appeared while he was writing The Metamorphosis. The article was written in answer to a question that asked in substance: Is religion a God who judges, or some kind of a metaphysical guarantee necessary in order to make man behave with tolerance and comprehension toward his fellow man? Malraux began his answer by declaring that he did not feel that the religions had succeeded in making men so behave. Often quite the contrary. The real problem according to him is, why men, at least some men, are willing to defend tolerance and comprehension for their own sakes. This willingness he calls a capacity for devotion, a capacity that is a necessity for any genuine religious belief or for carrying on a struggle such as his humanism. For the religious person this is God-given, but for Malraux it is "one of man's renascent powers, not like the instinets, but rather like heroism." The ol)vious association here is with the heroic sense and to a large degree this is accurate. Essentially, though, this "renascent power" is better described by conscience when this word is given the full significance discussed earlier in this chapter. This consciousness with its concomitant conscience helps, at least, to explain the capacity for devotion and the "acts of pity, heroism, and love" that are "the greatest mystcry of the universe." If conscience were universal and complete, Malraux's ethical ideal of a world in which every man would have his full dignity would be realized. To the degree that it is strengthened, the ethical dilemmas that beset the path to its accomplishment would be made less acute. Conscience is the real source, unexplained it is true, of the powers that are the gods in man, the powers that keep him struggling against the demon rather than surrendering to it. 


\section{ANDRE MALRAUX: TRAGIC HUMANIST}

The next phase in the ethical battle is treated in symbolic form when Malraux closes his article by stating, "For the past fifty years, psychology has been reintegrating the demons in man. I think that our task for the next hundred years, faced with the most terrible menace mankind has ever known, is to reintegrate the gods in him."

Malraux went to some difficulty to make the article available to me. A conversation with him went far toward clarifying his exact meaning, at the same time taking the development of his ethical thought one step further by returning to Ling and the idea of the improvement of individual sentiments. The demon remains an element within that must be dealt with. That Malraux's growing disillusionment with social and political formulas, which has reinforced a fundamental skepticism, has contributed to this emphasis on the inward approach, there is no doubt. It has led him to complement his religious agnosticism with a political agnosticism, a matter I have discussed elsewhere. The Gaullism he espouses is noticeably lacking in formal political theory. One positive result of this decline of faith in political action as such has been a growing unity and concentration of his ethical ideas, a unity that has been strengthened as he moved from action to an ever increasing meditation on its significance. One could well picture this growing unity and inwardness by two converging lines, that come to a point within man-and this brings us back to the significance of the preceding quotation. Malraux declares that he has come to believe that man's destructive and creative actions both spring from a common source within him. He associates his thought here with that of Goethe, the idea being essentially the same as Goethe's "demonic" drive: "That which we see as evil is only the other side of good." Malraux's use, during the last twenty years, of the term "Manichean" foreshadowed this stage in his development. He further compares his ideas to that of the "mothers" in the second part of Faust. We are dealing with a central wellspring of energy. The quotation concerning the gods and demons in man, then, means simply that our 


\section{ANDRE MALRAUX: TRAGIC HUMANIST 143}

efforts for the last fifty years, as exemplified by psychology, have been concentrated on the negative or destructive aspccts of this drive. The time has come to change the emphasis, to concentrate on the analysis and strengthening of its positive and creative aspects, of which art is one important manifestation. Without claiming to comprehend its source completely, we are safe in assuming that this positive aspect can best be described by Malraux's use of the word conscience.

The converging lines cross and then open up again. At the point of intersection is Ximenès' concept of the necessity for first encountering the world within ourselves in conscience. As conscience is strengthened, we move toward an ever widening communion and human dignity in its fullest sense. Thus, to paraphrase Malraux's definition of humanism, it is precisely by "sceking to discover man every where we find that which crushes him" that we can best move forward "refusing what the beast in us would have us do." 



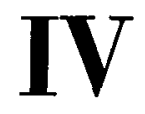

\section{ARTISTIC CREATION, OR THE STRUGGLE WITH THE GODS}

As composer, riddle reader, and redeemer of chance, did I teach them to create the future, and all that hath been to redeem by creating.

-Nietzsche, "Thus Spake Zarathustra" A man can defend himself only by creating.

- "The Conquerors"

It is art itself that makes the artist the rival of the gods.

- "Saturn" 

"The GoDs," Malraux tells us in The Metamorphosis of the Gods, in making reference to the ancient Greeks, "personified the powers that man does not govern, both in himself and in the universe." The negative or destructive powers in man are designated in Malraux's terminology as demons; they are opposed by man's creative powers, the gods within. This leaves undesignated the forces man does not govern in the universe; it is in this sense that we shall employ the term "gods" here, limiting it somewhat in order to concentrate on the powers or circumstances that have placed humanity where it is in space and time. For man, as Malraux visualizes him, is a solitary, fleeting accident, cast by the gods into a universe so vast and so indifferent to him that his own short existence seems to be of no significance, and all about him appears to be chaos. Man, and occidental man in particular, is driven by a desire to see this chaos reduced to an order that he can comprehend, to have, in Ling's words, "a coherent universe." Needless to say, many things interpose themselves between him and the accomplishment of this desire. In dealing with Malraux's vision of art, it soon becomes evident that two of these obstacles have an importance that dwarfs all others. The first is what Malraux calls "appearance." This can best be explained by saying that the forms of the earth, as given to man by creation, contribute to the chaos because, as they stand, they have no human significance; if there is an order, it is hidden. The second is time, the time that in Malraux's definition of destiny "flows perhaps toward eternity and certainly toward death." The certain flow toward death- 


\section{ANDRE MALRAUX: TRAGIC HUMANIST}

against which man is, in the final analysis, powerless-adds to the chaos by making man's brief span absurd in comparison to an eternal universe. And time very forcibly shows man that he will disappear from whatever order might lie behind the chaos.

The question of whether this chaos is real or only apparent, and apparent is a key word here, is a crucial factor in Malraux's philosophy of art. More often than not, man has felt that there is a pattern behind the confusion if only he could grasp it, and most of the great religions describe a universal order in which man has a function. There are two other possibilities: the chaos may be genuine or there may be order, but if there is, it is one in which man has no role. Seen from either of these last two positions, the relationship of man to the universe is chaotic. Malraux's own interpretation falls within one of these two areas; and lest there be any suspicion that art can alter the fundamentally absurd nature of either, in The Voices of Silence, he notes, "Art can not deliver man from being an accident of the universe." At best the artist can win only a relative victory against destiny as it is manifested by appearance and time.

Whether the artist feels that the chaos of the universe is real or only apparent, his attitude in the matter is the real guide of his creative activity; The Voices of Silence declares categorically, "All art is the slowly mastered expression of the artist's feeling about the universe." In other terms, real art begins with a consciousness of destiny, although destiny may mean different things to different people.

In trying to explain his concept of the "imaginary museum," which combines works of all periods and all areas, and at the same time to defend it against the charge of eclecticism to which it might appear vulnerable, Malraux says that he is far less interested in the multiple forms of these various works than in whatever mysterious element it is they all have in common. He is after what Ernst Cassirer refers to as a "philosophic synthesis," described as being the search "not for a unity of effects, but a unity 


\section{ANDRE MALRAUX: TRAGIC HUMANIST 149}

of action; not a unity of products, but a unity of the creative process." Malraux has no doubt that it exists. It is, in his words, "the deep current" that gives rise to all works of art, and "consciousness of destiny" is the lifegiving liquid of which this current is composed.

Essentially, it is the idea of the chaos of appearance or the chaos of the world as given by creation that makes it possible for Malraux to find unity in all artistic creation, whether it be religious or secular in nature. "All art," he declares, "seems to begin with a struggle against chaos." If art is also the expression of the artist's feeling about the universe, it follows that in Malraux's philosophy the artist begins by feeling that the universe is chaotic, at least as it appears on the surface. This is no less true for the artist whose inspiration is religious in nature than for one for whom there is only man. For the former, the chaotic nature of appearance hides a truth "beyond," which he seeks to attain and, in one way or another, to manifest. The religious artist, then, takes the apparent chaos and orders it in terms of the truth that is the dominant value in his life. For the nonreligious artist, there may well be no order behind the chaos except what he can impose in terms of artistic truth as he sees it; this will be a human order, one determined by man's desires. Malraux dramatized this by his now famous remark on the Greek acanthus. The acanthus, he said, is a stylized artichoke; it is what an artichoke would have been if man had been God. This is nothing other than a restatement of Baudelaire's dictum, "The primary business of an artist is to substitute man for nature."

Both types of artists are, in the final analysis, performing the same fundamental action, both are going beyond the chaos of the universe in an effort to attain some order, some truth. The recognition of this common starting point is vital for a comprehension of Malraux's aesthetics, for it enables him to account for both a constant elcment in artistic creation and a shifting in the attitude toward art through the centuries. Running parallel with the theme of human creative power is the idea that art itself is ever 


\section{ANDRE MALRAUX: TRAGIC HUMANIST}

at the service of something sacré, some dominant value beyond the artist himself. The attitudes of artists and societies toward their particular sacré and the elements that make it up have varied enormously, running the gamut from isolation to communion, from terror and fear through admiration to love and adoration, but always with the idea of some supernatural order. In these different attitudes toward the sacré, says Malraux, lies the most important source of the great religious styles. Obviously, an Assyrian artist, living in terror of most of his deities, is not going to be inclined toward the same style of picturization as, for example, a Christian who sees in Christ an intercessor and protector. This is an over-simplification of a problem that Malraux treats with great subtlety, but it serves to illustrate his thesis.

Whatever form this sacré may have taken and however much the fundamental attitudes toward it may have changed, this supreme value has been until very recently a religious one--even during the Renaissance, which, according to Malraux, saw everything through a filter of Christianity in spite of its apparent worship of man. With one exception, Malraux sees no gaps in the sequence but visualizes a process wherein one religious sacré succeeds another. The exception is pre-Christian Rome, which he feels was lacking in any real transcendental values. Significantly, he also feels that it did not produce any really great art. During the long period when the major values were religious, the concept of human creative power was, at best, of secondary importance since it was always buried under, or subordinated to, divinity. Art was not conceived of as a value in itself, but rather as the servant of religion. "A romanesque crucifix," he writes in the opening lines of The Voices of Silence, "was not to begin with a piece of sculpture; Cimabue's 'Madonna' was not first of all a painting; and even Phidias' 'Pallas Athena' was not first of all a statue." Although there were artists and works not subordinated to religion during this vast span of time, re- 


\section{ANDRE MALRAUX: TRAGIC HUMANIST 151}

ligion oriented by far the majority of all great art. This orientation began to change about 1860 with the rise of what Malraux refers to as our "agnostic civilization," the first in which one religion was not succeeded by another. Religion was still very much present, but it was no longer the supreme value that colored and oriented all else in life, including art. It was no longer, to use Malraux's own metaphor, "the aquarium in which all the fish swam." The fading of the religious sacré left a vacuum, which he strongly feels needs to be filled, but where art is concerned it has had a remarkable effect. This can be summed up by saying that for many people, art moved from being the servant of dominant values to being a major value in itself; it had, in a sense, become a sacré. Artistic truth, the world ordered as the artist feels it should be, became the answer to chaos. When Malraux said, "I feel about art the way most people feel about religion," he simply proclaimed his allegiance to human creativity; for the agnostic civilization, by pushing the idea of divine creativity into the background, had thrown human creativity into bold relief. When the great art works, religious and non-religious, are placed side by side in "the imaginary museum," it becomes obvious that it is human creativity that is common to them all. All begin with the same effort to go beyond the chaos and achieve some kind of significant order. "It [life] is a tale told by an idiot, full of sound and fury, signifying nothing," writes Malraux, quoting from Macbeth. "But," he adds, "Macbeth signifies something."

It signifies, among other things, one of the ways in which art is most truly a struggle with the gods; for Shakespeare took the disparate elements of a Scottish nobleman's life, the raw material given him by creation (or by the gods if one will), and created a powerful work of art. Malraux makes it clear that for him the artist recreates the world and that art is a "re-creation of the universe, opposed to creation." Writing on Goya, he says that the painter understood that "his real adversary was creation." The 
gods created the universe, and "it is art itself that makes the artist the rival of the gods." The gods are the external manifestations of destiny; and art, The Voices of Silence tells us, is anti-destiny.

From this emphasis on the chaos of appearance and on art as re-creation, it follows that no real artist can accept the world as it is given him. Whether he is aware of it or not, he must always be in a continuous and essentially Promethean revolt against the creation of the gods. There is, therefore, no such thing as a truly "realistic" artist who finds that all he has to do is to copy the world with which he is presented. "Whatever he may affirm," Malraux declares in The Voices of Silence, "the artist never submits to the world"; and at another point, "The great artist is not the transcriber of the world, he is its rival." He then goes on to link artistic creativity and the refusal to accept things as given to human creative power in general, to the axis of human potentialities on which his humanism turns:

As a creator, the artist does not belong to the collectivity that submits to a culture, but to the one which elaborates it, whether he is interested in this or not. His creative faculty does not subject him to a fatality that has become intelligible, but connects him to the millennial creative power of man, to cities rebuilt on ruins, to the discovery of fire.

For Malraux, human creative ability is always free, even when the objects it creates are destined for the service of an ideal other than art itself.

Not only does the artist refuse to accept the forms of the universe as well as those of the culture in which he lives, but to be truly an artist he must reject those of other artists. "I call an artist," Malraux declares, "a man who creates forms." Art is the result of a "divine" power within man that enables him to function, in one respect at least, like the gods. "All art," this vision shows us, "is a lesson for the gods."

Art as the creation of forms permits Malraux to deal effectively with 


\section{ANDRE MALRAUX: TRAGIC HUMANIST 153}

several troublesome aesthetic problems. First, as we have seen, it allows him to eliminate the idea of an absolutely realistic art that would copy the world. Such copying is, of course, possible, but Malraux would not classify the man who did it as an artist, for he fails to fulfill art's basic requirement. Secondly, it resolves the dilemma of the talented art counterfeiter; for even one as gifted as Van Meegeren, whom Malraux uses as his casc in point, does not create forms, he copies those of other artists. Finally, it does away with those craftsmen and works that blindly and unquestioningly serve any ideology, that which might be referred to as "official art"the standard pseudo-heroic portraits of Hitler, Stalin, Mao Tse-tung, and many of the formless, tasteless monuments that litter all occidental countries. The men who make these may be artisans, even superb ones, but not artists.

This vision of art and the artist makes it clear why Malraux's views on the matter put him at odds with most of his listeners when he delivered them at communist cultural congresses. The artistic faculty, as Malraux understands it, is completely incompatible with the totalitarian mentality; by definition, the artist cannot accept any culture en bloc, much less submit his creative power to its ideology. "Art is always multiple, even on the interior of a rigorous unity," Malraux wrote in his 1935 review of Ilya Ehrenbourg's Sans reprendre haleine. It was at one of the cultural congresses that Malraux sounded for the first time the note that The Voices of Silence was to make into a major theme: "Art is not a submission, it is a conquest." Here we are brought back inescapably to the vital role that Malraux's interpretation of Greek tragedy plays in all his thinking; for this is none other than the formula that he uses to describe the relationship of tragedy to destiny. He is fully aware that his analysis of the great tragedies is crucial to his approach to art as a whole. In the same speech, he stated that tragedy poses the central problem "with extreme brutality." 


\section{ANDRE MALRAUX: TRAGIC HUMANIST}

With slight variations in treatment but always with the same vision of the destiny-tragedy and destiny-art parallel, he returned to the issue in The Walnut Trees of Altenburg, The Voices of Silence, and The Metamorphosis of the Gods. "All art is a means of possessing destiny," he told those gathered at this 1936 congress.

Art as conquest is all the more vital because, in contrast with the domain of revolutionary action, it is an area in which one can "conquer without betraying oneself" in the process. No compromise with the forces of destruction is necessary. "In art," he told an interviewer, "nothing should ever be destroyed." An exchange between Gisors and Ferral in Man's Fate reveals another interesting, if far less important, aspect of this conquest. Gisors tells the financier, "A god can possess, but he can not conquer. The ideal of a god-is it not?-is to become a man while knowing that he will regain his power; the dream of a man, to become a god without losing his personality." Hence, the artist is not only the rival of the gods, in that like them he can create, but he tastes a victory that they cannot. Since they are all-powerful, they need not, and essentially cannot, conquer; for them there are no real obstacles. But the artist, with his more limited means, must struggle toward his conquest of the forms of the universe. In so doing, he is granted a form of satisfaction denied the gods themselves. As always with Malraux, there are compensations in struggle.

Malraux began very early in his literary career to work on this concept of art as the re-creation or conquest of the chaotic appearance of the universe. When Ling, in The Temptation of the West, wrote of the Europeans, "You want a coherent universe, you create it," he was commenting on the mental structures that man has built to explain the universe, but he was also describing the function of art. Ling's use of the pronoun you in reference to the Europeans is indicative of a divergence between his approach and the occidental one, a divergence that carries over into the realm of art. And it is, more than anything else, Ling's position on art and museums that 


\section{ANDRE MALRAUX: TRAGIC HUMANIST 155}

makes untenable the thesis that The Temptation of the West is a total rejection of the European viewpoint. In the novel, Ling writes to A.D.:

Your museums give me no pleasure at all. The masters are confined in them. They argue. That is not their role nor is it ours to listen to them. And I am always disappointed by these places where you prefer the satisfaction of judging to the finer joy of understanding.

The museum teaches, alas, what foreigners expect of beauty. It stimulates them to make comparisons and leads them to feel above all, in a new work, what is different about it.

Ling's words show not the slightest awareness of "the deep current" that gives rise to all the different works, the common drive to re-create the forms of the earth that is for Malraux one of the major revelations of a museum and particularly of his imaginary one. The argument that Ling's statements speak for an early Malraux who has not yet begun to conceive the idea for the imaginary museum, likewise does not hold water. As was the case with the absurdity revealed by European analytical thought, Malraux gives the final word to the Occident. It is only where the ethics of force are concerned that Ling's views encounter no real challenge from A.D. The latter's rejoinder on the matter of European museums already contains, in embryo, the imaginary variety that Malraux will later develop; and it is, incidentally, one of the temptations of the Occident from which the book takes its title:

But it is no longer Europe or the past that is invading France in this beginning of the century. It is the world which is invading Europe; the world with all its present and all its past, its collected offerings of living or dead forms and meditations. This great spectacle that is beginning, my dear friend, is one of the temptations of the Occident.

Taken by themselves, these words show that A.D. is already thinking in terms of the gathering of art from all periods and all areas that forms the 


\section{ANDRE MALRAUX: TRAGIC HUMANIST}

basis of Malraux's imaginary museum, but they do not answer Ling's charge that the main result is an effort to find out what makes the individual works different from one another. When A.D. continues his interpretation, we find that he is stating, in an incomplete form, the common drama of the artist at grips with the forms of the earth:

That is the revenge of the spirit. The stream of living forms rumbles in it like an underground river, but it draws from among them these great simple forms, even if they may be swept away later, in order to have them reign over the others to make them submit to its wishes.

This is still rudimentary, but it does show a preoccupation with the idea of an element common to all art. The idea of continuity and a common source is strengthened by such images as "the stream of living forms" and the "underground river." In The Voices of Silence they will become "the deep current" that stimulates all works of art. That the same flow in Malraux's art runs from this early work to the latter is demonstrated when, in The Temptation of the West, he refers to art as "the revenge of the spirit" and, in The Voices of Silence, changes it but little to "the eternal revenge of man."

This flow, or rather the emphasis on it, goes underground during the period of Malraux's adventure and revolutionary novels, possibly because art is in a sense a struggle with the universe; and, as he writes in The Walnut Trees of Altenburg, while one is threatened with ever present violent death "the universe becomes an indifferent menace.' Occasional remarks scattered throughout the novels indicate the author's continuing interest in the fundamental problem of human creativity versus the forms of the earth. It is implicit in Garine's declaration that "a man can defend himself only by creating," even if Garine's own creation, a revolutionary organization, might be very difficult to classify as art. When Claude Vannec declares that "he wants to wrest his own images away from the stagnant world that possesses 


\section{ANDRE MALRAUX: TRAGIC HUMANIST 157}

them," he is stating in other terms the position of the artist at grips with appearance. Both Man's Fate and Man's Hope contain several characters intensely interested in art and Malraux always finds a way to let them air their views. Kama the painter's reply to Clappique's question, Why do you paint?, is only a modification of the idea of penetrating the appearance of the world to attain some kind of order. "The world is like the characters of our writing. What the sign is to the flower, the flower itself is to something else. Everything is a sign. To go from the sign to the thing signified is to go deeper into the world, to go toward God." This differs but little from Malraux's explanation of the creative process of the religious painter. The difference, which lies mainly in Kama's belief that everything in the world is a sign, whereas for Malraux it is something of an obstacle, does not obscure the fact that in both his vision and Kama's the forms of this world are something the artist goes beyond. Kama, like Ling, is an oriental and, also like him, does not see art as re-creation, at least he does not mention it as such. It is this conspicuous absence that separates the art philosophy of the two fictional characters from Malraux's own. Malraux may well believe that such an idea is unacceptable to any mind trained in most oriental philosophies and religions. We are brought back to the dichotomy shown by Ling's statement that "you [the Europeans] want a coherent universe, you create it."

With The Walnut Trees of Altenburg the concept of art as the re-creation and conquest of appearance again becomes paramount. In their search for an element common to men of all cultures, the intellectuals at the Altenburg colloquia return time and again to the problem of the nature of artistic creation. Malraux has, in fact, based a large part of his refutation of the Spenglerian theory of isolated and distinct cultures on his belief that some form of artistic creativity is to be found in every culture. However, it is in the attempts to describe the nature of art that we find Malraux moving toward his concept of re-creation of the world. Vincent Berger's definition 


\section{ANDRE MALRAUX: TRAGIC HUMANIST}

ties the nature of Greek tragedy to that of art as a whole; equally significant for the unity of Malraux's humanism is Berger's interpretation of art as rectification, an approach that puts it squarely on an ethical basis:

Our art seems to me to be a rectification of the world, a means of escaping the human condition. The main confusion derives, I think, from the fact that we believed-and where Greek tragedy is concerned, this error is astounding-that to represent a fatality was to submit to it. Not at all. This is almost the same as possessing it. The sole fact of being able to represent it, of being able to conceive it, makes it escape from true destiny and reduces it from the implacable divine scale to the human scale. In its essential characteristics our art is a humanization of the world.

Berger equates rectification and humanization by making art equal to both of them. This three-part formula reveals that Malraux's concept of art, as we have seen it expressed in The Voices of Silence, is not yet fully evolved, but it also demonstrates that the artistic and the purely ethical phases of his humanism function in basically the same way. On the artistic level, the rectification of the world brought about by human creativity leads to a humanized world. The struggle with the demon is, also, essentially a process of rectification that leads to a humanized mankind, one that is more man and less beast.

In the passage referring to the Greek acanthus as a stylized artichoke, Berger goes on to say that this is the same thing as saying it is humanized, or "as man would have made it had he been god." Thus far he seems to be on the path to Malraux's present idea of art, but he diverges from it in the continuation of his remark: "Man knows that the world is not made on the human scale; he wishes that it were. And when he reconstructs it, it is on this scale that he does so." In his emphasis on reconstruction as the function of artistic creation, Berger is virtually making Malraux's own point; but in his choice of change of scale as the object of this process, a choice he 


\section{ANDRE MALRAUX: TRAGIC HUMANIST 159}

also made in the passage on rectification, he makes an error that results in the difference between a partial and complete statement of Malraux's own position. Neither Greek tragedy nor the acanthus differs primarily from the raw material the artist used to make them. There is, for example, no reason why the architectural acanthus should not be vastly larger than any artichoke that ever grew. Where tragedy, and indeed all art, is concerned, the change is far more profound than a mere change of scale; it is not a fundamental or even particularly important aspect of the artistic activity, which Malraux interprets as the imposition of humanly significant forms on those of the universe.

The men gathered in the Altenburg priory never quite reach this interpretation of art, but Vincent's brother Walter, who told the story of Nietzsche's song in the Saint Gothard tunnel, comes close to the heart of the matter in his feeling about the significance of this song. In so doing, he brings art back to the starting point of MaIraux's tragic humanism:

I had just discovered something. Something important. In the prison of which Pascal speaks, men have succeeded in finding within themselves a response that imbues with immortality, if I dare use the word, those who are worthy of it. And in this railroad car. And in this car, and a few times afterward, I say only a few times, the millennia of the starry heavens have seemed to me as blotted out by man as our poor destinies are blotted out by the starry heavens.

The greatest mystery is not that we have been cast at random among the profusion of matter and that of the stars. It is that in this prison we have drawn from within ourselves images powerful enough to deny our nothingness.

The prison in question is Pascal's image for the human condition. Image is the key word here. What Pascal did in his famous Pensées was to take the raw material of man's fate and order it in a vivid, significant image of his 


\section{ANDRE MALRAUX: TRAGIC HUMANIST}

own choosing. In the broad sense we may say that the creative function of art is to make images. It is no coincidence that Nietzsche should have been the other figure in this picture of man imposing his will on the forms of the universe. His Zarathustra preached: "All it was is a riddle, a fragment, a fearful choice-until the creating will sayeth thereto: 'But thus would I have it." "

As Malraux moves progressively nearer to clarification of his concept of art as a struggle against the chaos of appearance, it becomes increasingly evident that he sees in art one of man's most powerful weapons against the absurd. Basically, it is the feeling of universal chaos or lack of significant order in the relationship of man and the universe that gives rise to the feeling of absurdity. But absurdity itself is a human concept; and, as Albert Camus notes pointedly in The Myth of Sysiphus, for absurdity to be there must be human consciousness in contact with something it considers absurd. Consciousness of the fact that the forms of the earth and the universe have no human significance play no small role in giving rise to the sentiment of human absurdity. Thus, by transforming these forms into others that do have a human meaning, the artist is taking a major step in the rejection of absurdity itself. Artistic creation, viewed in this light, is a refusal to accept the absurdity of the forms given to man by original creation. Malraux weaves this idea into his interpretation of Goya in Saturn and shows once again that Prometheus is always in the back of his mind when he thinks of the artist struggling with the gods. Writing of the Spaniard's feeling when faced with a universe in which man is solitary and where he contributes to his own absurdity by the savagery with which he treats his fellows, Malraux concludes:

But he is a painter and by this very fact this feeling is not reducible to the absurd. However profound the dependence, however constant the secret seal of death, the artist does not believe that they are in advance the conquerors of the vertiginous moment when man possesses them by imposing his trans- 


\section{ANDRE MALRAUX: TRAGIC HUMANIST 161}

figuration on them. It is not because he pictures tortures that Goya is the rival of the god who permits them, but because he converts each of them into a cry that is part of Prometheus' nocturnal plaint.

Whether destiny manifests itself as a force crushing man, or as a universe that reduces him to insignificance, or as a cosmos that has no significance in his terms, or as human cruelty, human creative power can transcend destiny by transforming it into an art form-the form the artist wants to give it as opposed to the one the gods created. "The creative act," according to The Voices of Silence, "maintains throughout the centuries a reconquest as old as man himself." In a passage from this same work that recalls Claude Vannec's conception of "wresting his own images from the stagnant world that possessed them," Malraux crystallizes his concept of art as a refusal to accept the forms that destiny has put forward:

Art is born specifically from the fascination of the ungraspable, from the refusal to copy the spectacles, from the will to wrest the forms from the world to which man is subject in order to insert them in the one he governs. The artist is aware of the limits of this uncertain possession, but his vocation is linked, at its origin and several other times with lesser intensity, to a violent feeling of adventure.

Adventure brings us to the other aspect of chaos against which the artist struggles, that brought about by time; for art, as Malraux envisions it, is as much an adventure in time as in the creation of form. If the latter had been treated first, it is only because the forms must first be produced before they can begin their movement through time. When Malraux begins his definition of destiny by stating, "Time flows perhaps toward eternity, and certainly toward death," he brings us to the heart of the problem. The human mind can conceive of eternity or immortality, and in Saturn we are informed that "it is no less in the nature of man to want to be immortal than it is to know that he is man." But to know that one is a man is to 


\section{ANDRE MALRAUX: TRAGIC HUMANIST}

know that one must die. Death cuts short the dreams of eternity, placing on man the "secret seal." Malraux has more than once repeated the definition of man as "the only animal who knows he must die." While death is not all of destiny, it is certainly the manifestation that imposes most forcibly on man an awareness of the irreversible flow of time. The hard fact of its inescapability does this so well that, in the final pages of The Voices of Silence, Malraux will question his own earlier statement about eternity to wonder if "man is obsessed with eternity, or with escaping the inexorable dependency clamped on him by death." With death visualized as a form of servitude or dependency, it follows logically that a man like Malraux, who characterizes culture as "the ensemble of everything that makes man freer," would view one function of art as an effort to liberate man from the bondage of death, at least in a relative sense. The idea of transcending death by creating something that will continue past one's own lifetime is banal in the extreme; and if this were all Malraux's art theory had to offer, he would not enjoy the reputation he does as an art critic. Human mortality clearly represents for him the most obvious evidence of the flow of time, but he is fully aware that, particularly where art is concerned, the problem of time is far too complex to be handled so simply. In an effort to encompass this complexity without losing the emphasis on death, Malraux alternates between using time and death in parallel contexts. In The Voices of Silence he observes, "In the eyes of the artist, things are first of all what they can become in a privileged domain where they would escape from death." A few years later, in The Metamorphosis of the Gods, he will ask, speaking of Vermeer's attitude toward his subjects, "But didn't Vermeer want to save something from the effects of time?"

Malraux's most significant treatment of the relationship of time and art did not occur until he wrote his great books on art, but even his earliest writings reveal that he was aware from the first that it was a complex and basic problem. When the European correspondent in The Temptation of 


\section{ANDRE MALRAUX: TRAGIC HUMANIST 163}

the West explains to Ling the Western attitude toward art, he omits any mention of death but talks in terms of time, forms, and values, and in so doing gives the basic elements of a concept that Malraux was not to develop fully until a third of a century later in The Metamorphosis of the Gods:

The occidental spirit always tries to give a durable character to the things to which it attributes value. There is in this an attempt to conquer time, to make it the prisoner of forms. But this attempt itself is possible only in a world organized by man. It is he who crowns himself and reduces to nothingness the existence of the things that he does not select.

There is a young man's arrogance implicit in the attitude described in the last two sentences-an arrogance that will disappear from Malraux's writing on art as he grows older, and particularly as he develops an increasing appreciation of religious art. This same formula, minus the presumptuousness, will reappear in The Voices of Silence when he writes of "forms chosen by man, reduced to man, the forms by which man expands his values to fit the idea he has of the universe." Far more significant is the fact that when he talks of the forms that man selects and of making time the prisoner of forms, he has already stated the seminal ideas from which virtually all his art theory is to derive. One is inclined to feel that, although Malraux might not yet have recognized the complete meaning of A.D.'s statement, he was aware that it expressed a key idea, for he has the European append, "There is no longer any art that I cannot understand." There is no lack of selfconfidence in this statement either. To move from what is essentially an analysis of Western art to an interpretation of all art is a very considerable step, but it is made possible by the "imaginary museum." And with The Metamorphosis of the Gods Malraux completes the cycle by drawing on oriental philosophy for an approach to the analysis of Western art.

With one possible exception, to be dealt with in another context, the books between The Temptation of the West and The Walnut Trees of Al- 


\section{ANDRE MALRAUX: TRAGIC HUMANIST}

tenburg contain nothing on the question of the relationship of art and time quite so pregnant with possibilities as the few sentences just considered. Practically all of them, however, contain something that indicates a continuing occupation with the matter; but probably because of Malraux's involvement during this period with the world of physical violence, they tend to make death rather than time their point of reference.

Perken, in The Royal Way, is no artist, and indeed he shows no awareness whatever of art as such, but the way in which he intends to implement his struggle against death is nothing but a transposition onto a rudimentary non-artistic level of the idea of art as a means to continued existence: "To exist in a great number of men, and perhaps for a long time. I want to leave a scar on this map." This last sentence, one of the most frequently quoted lines from Malraux's novels, is most often treated as being simply the expression of Perken's intense personal ambition. To a large degree this is justified, but one should not lose sight of the fact that it has precisely the same metaphysical origin as one aspect of the art-death relationship. The artist who transcends his own death by reordering the forms of the earth also leaves "a scar on the map." Both are struggling with destiny. It is left to Perken's comrade, Claude Vannec, to put exactly the same proposition in terms of the artist. After trying vainly to make Rameges, director of the French Institute at Saigon, comprehend his view of the artist, Claude ends by reflecting, "He would understand me much better if he recognized that what attracts me is the fierce desire of men to defend themselves against death by means of this uncertain eternity." The natural complement of this is Garine's already cited remark: "A man can defend himself only by creating." When Kama, in Man's Fate, is asked if he would paint differently if he knew that he were soon to die of an incurable disease, he answers, "Not differently, but better"-a clear indication that an awareness of death can contribute to the quality of artistic production. For Kama, "the approach of death would, perhaps, enable him to put into things enough fervor, 


\section{ANDRE MALRAUX: TRAGIC HUMANIST 165}

enough sadness, so that the forms he painted would become comprehensible signs; so that what they signified and what they hid would be revealed."

Throughout the revolutionary novels the vision of art against death and time is one of man fighting to liberate himself from the servitude of destiny. It is, to employ the words Garcia uses with respect to the Mexican revolutionary painters, "the language of man in struggle." The fight is characterized by its defensive nature with no real mention of victory. A.D. speaks of what Western man tries to do; Vannec and Garine of defending oneself; Kama of what he can perhaps do. We might conjecture that Malraux's direct participation in numerous physical struggles, so many of which found him on the losing side, had colored his attitude toward the possibility of art's winning the battle against time. As with every important aspect of Malraux's thought, however, The Walnut Trees of Altenburg marks a major transition in this respect, and here we find him talking in terms of at least partial victory. "But I know," Walter Berger asserts, "that certain works resist the vertigo that comes from the contemplation of our dead, of the starry heavens, of history. There are some of them here. Not these Gothics; you know the head of a young man from the Acropolis museum? The first sculpture that represented a human face, simply a human face freed from the monsters, from death, from the gods. That day man, too, made man from clay." Berger's exalted final words reintroduce the theme of the artist's godlike ability to create, and his choice of words pointedly make the latter a rival of the god that did the original creating. The fact that the head has come through two thousand years, far outreaching the life span of the sculptor, indicates a victory over time and death. Its survival leads to what Malraux calls in Le Musée imaginaire de la sculpture mondiale "the enigmatic presence in life of what should belong to death."

This physical survival is only an elementary, but necessary, aspect of the triumph, the first note from which Malraux will compose the song of victorious tragedy that is The Voices of Silence. One of the themes is, logi- 


\section{ANDRE MALRAUX: TRAGIC HUMANIST}

cally, that of freedom from the dependence that death clamps on man. In his analysis of the common element in major artistic works, Malraux indicates that the artist's freedom has implications that go far beyond himself:

And finally we distinguish what it is that unites all of them to so many other works. The artist, by his slow conquest, has powerfully freed himself from his dependence. They bring to all who can understand their language the most persuasive echo of his liberation. Posterity is the gratitude of men for victories that seem to promise their own.

In Malraux's philosophy of art, freedom from dependence has at least four meanings, two of which-freedom from the forms of the earth and freedom from the dictates of society-have already been discussed. There are two others: On the purely aesthetic level, there is freedom from dependence on the style of the artist's masters and teachers. In the early stages of his career, virtually every artist is more or less subjected to the style of those from whom he learns. The great artist struggles to liberate himself from this bondage, and eventually bursts through into the freedom of his own style. The fourth meaning is that of relative freedom from time and death, the freedom with which we are particularly concerned here.

This continuing recurrence of the theme of freedom brings us inevitably back to the fundamental Pascalian prison image of the human condition; for no matter which form Malraux's humanism takes, there is always man struggling against some form of servitude. Just as there is no real dignity possible for any man who is completely dependent upon another, so in Malraux's vision there is no full artistic dignity or stature possible for the artist who is still dependent upon the style of another. The parallel extends also to the idea of fraternity. Time, death, and subjection to another's style isolate the artist just as surely as humiliation isolates man in general. Conquest of his own original style unites the artist with the flow of human creativity that goes back as far as man himself. The survival of his work 


\section{ANDRE MALRAUX: TRAGIC HUMANIST 167}

makes him part of a fraternity reaching through the depths of time, a communion spanning millennia. As might be expected, Greek art is one that best bridges the gap of time.

In the sense in which Amphitrite was the goddess of the sea, the figure that makes the waves helpful, Greek art is our god of Greece. It is art, and not the Olympians, that expresses Greece to us in its highest form, victorious over time and fraternal; it is through art alone that Greece reaches our souls. It expresses what was, through Greece and inseparable from it, the particular form of a divine power to which all art bears witness. The man suggested by the multiplicity of these powers is an actor in the vastest of all adventures, and also the deep root from which springs offshoots that sometimes interlink and sometimes are unknown to each other. The victory that he won over the demons of Babylon re-echoes dimly in some secret corner of our soul.

This vision of a creative adventure uniting the human race throughout space and time is at the heart of Malraux's refutation of Spengler. The tree image employed here is not fortuitous, for Malraux also uses it in his treatment of the "fundamental," the other aspect of his answer to the author of The Decline of the West.

Obviously, the fact that, two thousand ycars later, we feel an affinity for what survives of Greek art is not an answer to a theory of history as complex as Spengler's. To begin with, Malraux's objection to the theory of cultural isolation is based only on degree, not on kind. For Spengler the isolation is complete, for Malraux only partial. As early as The Royal Way, Malraux had Claude Vannec declare that "in depth, every culture is impenetrable for another," and he has not since shown any inclination to gainsay his creation's remark. It is reflected by his observation in The Voices of Silence that "we can unite the knowledge of the church fathers to that of the great thinkers of India, but not the Christian experience of the first to the Hindu experience of the second. We can unite everything, 


\section{ANDRE MALRAUX: TRAGIC HUMANIST}

except the essential." The fundamental experience of being a member of a specific culture is not, as Malraux sees it, transmittible, even by the finest art. One needs only to recall the vital role played by experience in Malraux's life and work to realize that he is not using the word essential lightly.

But Malraux feels the need to answer Spengler too intensely to drop the matter simply because he cannot refute him completely. In André Malraux and the Tragic Imagination, W. M. Frohock has shown that Malraux was preoccupied with the question as early as 1928 . The 1948 speech to the Gaullists, reproduced as the Postface to the definitive edition of The Conquerors, reveals an understandable objection to German cultural theory in general. This same speech illustrates Malraux's belief that some phases of culture do get through and, at the same time, provides the key word in Malraux's approach to the matter. "The problem that is posed here," he stated, "is to know what it is that assured the partial transcendence of dead cultures. I am not speaking here of eternity, I am speaking of metamorphosis."

"Metamorphosis," along with the terms "resurrection" or "renaissance," is at the heart of the artistic aspect of Malraux's reply to Spengler. One of his most significant contributions to the philosophy of art, this concept animates a vision in which those elements of past art that come down to us, not only merely survive, but are enriched and renewed . Malraux's theory of metamorphosis is complex and must be viewed from at least three angles: that of the artist, that of the art object, and that of the viewer (in the largest sense of the word). The role of the artist tends to become almost secondary in this vast drama of cultural links that bridge centuries and even millennia. The artist's function is put succinctly when Malraux answers the question of the source of a culture's transcendence not many minutes after posing it. "A culture is reborn," he asserts, "when men of genius, seeking their own truth, draw from the depths of the centuries everything 


\section{ANDRE MALRAUX: TRAGIC HUMANIST 169}

that resembles that truth, even if they are not aware of it." The idea of the artist or philosopher who finds in the past a vision having important elements in common with his own is anything but new and original. Malraux, however, adds two new factors that give his interpretation an increased significance. For the last quarter of a century, he has been insisting on the importance of the fact that ours is the first generation to have the past and present of the entire world as its heritage, a point of obvious value in the struggle toward a universal humanism. For the artist, it provides by far the richest source ever known from which he can annex the elements that serve his own truth. But if, in so doing, he were to accept and copy these elements as he received them, he would not be acting consistently with Malraux's interpretation of the artist as a re-creator. The artist's function in the process of metamorphosis is to transform the elements from the past, to give them a renewed and broadened existence. As part of this process, he can, in the formulation of his own truth, combine elements which were contradictory in their original states, as well as those which, because of spacc or time, had no contact with one another. The result should be a new work whose form cannot be predicted in advance. And not only our art but our entire culture is offered the possibility of exploiting this rich vein of possibility if we will to do so.

Our culture, therefore, is not made up of reconciled pasts, but of irreconcilable parts of the past. We know that it is not an inventory; that the heritage is a metamorphosis; that the past must be conquered; that it is within us and for us that the dialogues of ghosts, of which rhetoric was so fond, come alive. What would Aristotle and the prophets of Isracl have exchanged on the banks of the Styx except insults. In order that the dialogue between Christ and Plato could be born, it was necessary for Montaigne to be born. . . And our resurrection is not at the service of a preconceived humanism. Like Montaigne, it calls for a humanism that is not yet conceived. 
With the theme of the inheritance of cultures, we come to the important aspect of metamorphosis that finds the focus shifted from the artist to the work and the people and civilization that inherit it. In the part of the UNESCO speech that reveals him as once more preoccupied with answering Spengler, Malraux told his listeners, "The true problem is not the transmission of cultures in their totality, but of knowing how the humanistic quality of each one has come down to us and what it has become for us." The problem of what past works have become is pivotal in metamorphosis. Obviously, we must have some common ground with a work from the past or it would awaken no significant response. For some this could be an ideal of beauty shared by men of all times. Not for Malraux. "I do not believe," he wrote as early as 1935, "in some mysterious Platonic beauty that privileged artists throughout the centuries have succeeded in attaining." All art, our own and that of the past, has in common, of course, the fact that it is the result of human creative power; but this is not the vital issue where metamorphosis is involved, for by no means has all the art we possess from the past undergone, at least as yet, any real metamorphosis. For this to take place, it must provoke some vital reaction in viewers from a civilization different from that in which it was originally created. A large part of the art works collected in our museums produce no such response, resting dormant or stimulating at most a passing interest. Malraux's own reactions are a good case in point. There are few men who have an acquaintance with art of almost every period and every area that is so wide and so clearly coupled with a sympathetic appreciation of their artistic value. Nevertheless, he is admittedly unresponsive to certain works whose technical excellence he respects: those of Raphael, for example. To others he reacts with such intensity that it is evident that some chord struck in the work also vibrates in Malraux himself. His long essay on Goya is clearly a result of this phenomenon. According to Malraux, parallel phenomena take place on 


\section{ANDRE MALRAUX: TRAGIC HUMANIST 171}

a large scale when a period or society resurrects from the past or from a different area an art or a culture that has something vital in common with itself. To cite an example from The Voices of Silence, Malraux declares that the major reason for the enormous growth of interest in barbaric art is to be attributed to the fact that recent history has made us aware that the demon in man is still a terrible menace, and that the demon is more or less present in all barbaric art. Hence, it has acquired a significant reality for us.

But even if art that is not our own does answer something within us, it obviously does not mean to us what it meant to the civilization in which it arose. In Malraux's terms: "None of us knows what the psychic state of an Egyptian fellah was when he gazed at a statue of the third millennium." The central problem, then, is that we are both like and unlike those civilizations whose art we truly resurrect. Malraux's metamorphosis suggests that something important held in common with another culture causes us to resurrect its art, but that the differences between the two cultures impart new meanings. In a sense, the art is created again. "The Renaissance made antiquity just as much as antiquity made the Renaissance,' we are told in The Toices of Silence. Thus man and his art win a significant victory over time, not only preserving the cultural heritage, but enriching it.

The relationship of art to the civilization viewing it has long interested Malraux; and through more than a quarter of a century, the relationship has developed from a problem into a major element in his vision of art as anti-destiny. In 1930, contemplating the Gothico-Buddhist statuary brought to Paris from the Pamir, he wrote, "Our mind is halted (and attracted) here because it seeks references, ceaselessly has the impression of approaching them, and does not find them. I have rarely felt so violently to what a degree the action of our minds, with respcct to a work of art, is linked to a play of suppositions: epoch, form of civilization, and psychology of the artist." The Royal Way, which appeared in the same year, al- 


\section{ANDRE MALRAUX: TRAGIC HUMANIST}

ready moves toward an answer to the puzzlement expressed in these lines. Claude Vannec incorporates the first stages of his creator's theory of metamorphosis in his effort to explain his reaction to museums:

I say then that the essential value accorded to the artist hides from us one of the poles of the life of a work of art: the state of the civilization that views it. One would say that in art, time doesn't exist. What interests me, you understand, is the decomposition, the transformation of these workstheir most profound life, which is made up of the death of men. Every work of art tends, in short, to become a myth.

For me museums are places where the works of the past, having become myths, sleep until the artists call them back to a real existence. And if they touch me directly, it is because the artist has this power of resurrection.

In depth every civilization is impenetrable for another. But objects remain and we are blind before them until our myths agree with theirs.

The Spenglerian note of the next to the last line, sounded in this context and followed as it is by but, indicates not only that Malraux is thinking in terms of refutation but that already, seventeen years before The Psychology of Art, he feels that art will furnish one of his best weapons for the task. Although the answer is incomplete in this passage, there is nothing in it that Malraux will seriously modify except by way of expansion and development. The brief remark on the nonexistence of time in art contains the seed of his later treatment of the problem; and the "agreement of myths" as the path of communication and resurrection, he finds insufficient and requiring treatment.

Perhaps because it is Malraux's only novel with a search for art of the past as a major theme, but The Royal Way is the only novel prior to The Walnut Trees of Altenburg to wrestle with the question of metamorphosis. Absence from the novels does not, however, mean absence from Malraux's thoughts. During this period of writing leftist novels and fighting for leftist causes, he was also lecturing leftist audiences on his art theories. These 


\section{ANDRE MALRAUX: TRAGIC HUMANIST 173}

talks, recorded in Commune from 1934 through 1936, provide a fascinating picture of Malraux's mind at grips with the implications of a problem whose fundamental nature and importance he has already recognized, perhaps intuitively. In 1934, he was at work on the first stages: what the work of art really signifies, and how this significance is transmitted. At this point he is dealing largely with the means by which the original artist communicates with his audience. In so doing, he retains the idea of myth formulated by Claude Vannec: "Since the artist works essentially to create his own myth, we still need to explain how this myth is transmitted and how the work of art lives." Turning from the plastic arts to literature, he chooses the works of Baudelaire and Fromentin as being representative of two very special types of sensitivities. He goes on to say that their works evoke a favorable response because "in them a certain number of readers find their sensitivity expressed on a higher plane and hence justified." In the same speech Malraux states that while he does not believe in a Platonic ideal beauty, he does believe in an "agreement of sensitivities." He is on a relatively superficial plane and offers a very incomplete explanation of the complicated relationship between the artist, the work, and the viewer. Malraux's own dissatisfaction with this explanation is indicated by this observation: "It would evidently be necessary to introduce some nuance into this thought." Nonetheless, rudimentary though it may be, this "agreement of sensitivities" is an important factor in bringing about a resurrection of art without which metamorphosis cannot take place; it provides a basic common chord.

Eight months later, another lecture shows that Malraux has moved a considerable distance along the path toward the concept of metamorphosis. $\mathrm{He}$ is less interested in the original effect of the work of art than in later ones produced in its movement through time; for, as he notes, "A work of art is an object but it is also an encounter with time." Working from this larger perspective, he shows how art is born and reborn in answer to some urgent need. And in language that recalls Claude Vannec's, he tells his 


\section{ANDRE MALRAUX: TRAGIC HUMANIST}

audience that when no need is present, we are blind to the significance of an art work.

Every work of art is created to satisfy a need, a need that is passionate enough to give birth to it; then the need withdraws from the work like the blood from a body and the work begins its mysterious transformation. It enters the domain of shadows. Only our need, our passion can bring it back. Until then it will remain a great blank-eyed statue, in front of which parades a long cortege of the blind. And the same need that will direct one of the blind toward the statue will make them all open their eyes at the same time.

Here is resurrection or renaissance stated as poetically as Malraux ever states it, even in The Voices of Silence. From the symbolism emerges the fact that a civilization or an artist resurrects a past art because something in it corresponds to fundamental needs.

This brief talk (it occupies less than three printed pages) carries the development far beyond the rebirth of a work of art; for Malraux then moves to the role of those who do the resurrecting - a role that must, according to him, be an active one. "However, there is a sense to this great movement. Art, thoughts, poems, all the old human dreams-if we need them in order to live, they need us in order to live again. They need our passion, our desires, our will." With the last two words, metamorphosis moves into the main stream of Malraux's theory of art: the idea that art represents an imposition of the human will. Just as the artist must struggle to conquer the forms of the earth rather than submit to them, so must he, and man, fight to master the heritage of the past. "The heritage is not transmitted, it is conquered."

Still within the framework of this same talk, Malraux goes on to the completion of his theory of metamorphosis. If the artist's conquest of form leads to something entirely new, so the conquest of the heritage of the past leads, not to a simple preservation of that heritage, but to its metamorpho- 


\section{ANDRE MALRAUX: TRAGIC HUMANIST 175}

sis into something new. Conditioned by all that separates them from the civilization in which the art was produced, the artist or civilization receiving the heritage will impose on it a new meaning, a new language. Malraux talks here of "once more imposing on the face of the past its new metamorphosis. For every work of art becomes a symbol and a sign, but not always of the same thing. A work of art is a possibility of reincarnation." A year later, in another speech, he will alter this only to say that it is "an infinite possibility for reincarnations."

At this point, a full ten years before the first volume of The Psychology of Art, Malraux already has well in hand all the elements of metamorphosis, his vision of art as an answer to Spengler. Oddly enough, although the Altenburg intellectuals are trying to answer this same philosopher, and although they do not neglect art as a possibility, none of them hits upon a statement comparable to the speech just discussed. It is Count Rabaud who sees art as a link with the past and a total refutation of the Spenglerian hypothesis:

The great artist, gentlemen, establishes man's eternal identity with himself. By the way in which he shows us a particular act of Orestes or Oedipus, of Prince Hamlet or the brothers Karamazoff, he brings close to us these destinies that are so far from us in space and time. He makes them fraternal and revealing. Thus, certain men have this great privilege, this divine faculty, of drawing from within themselves that which delivers us from time, space, and death.

In terms of Malraux's theory, Rabaud is in error from his very first sentence. Everything Malraux has written on the subject, beginning with Vannec's insistence on "considering the state of the civilization viewing a work of art," indicates that he does not accept the idea that man is eternally identical with himself-certain common elements yes, identity no. If man were eternally identical, the young Malraux gazing at Gothico-Buddhist 


\section{ANDRE MALRAUX: TRAGIC HUMANIST}

statuary would have had no difficulty in finding points of reference--all art would be resurrected equally, and there would be no metamorphosis. $\mathrm{Ra}$ baud's absolute statement is actually so naive from Malraux's point of view that one is led to believe that the author tailored it to fit a man who was long on intellect but decidedly short on the actual experience of living, a serious deficiency in Malraux's eyes. Vincent Berger, who had lived in other civilizations, knew from experience that men are not identical. It is he who pronounces what is obviously Malraux's own opinion of Rabaud's theory, "subtly banal, common then to a number of intellectuals." Rabaud is so far off the mark and yet so near to it; with the exception of the first line, most of what he says is couched in Malraux's own terms and coincides accurately with his vision of art.

With The Voices of Silence all the elements are recombined and metamorphosis emerges as the book's predominant theme, the one idea that, more than any other, incorporates all the major aspects of art as a human conquest of form and time. Early in the book, Malraux leaves no doubt that he intends metamorphosis to be its unifying thread:

Metamorphosis is not an accident, it is the very life of the work of art. We have learned that if death does not force a genius to be silent, it is not because he prevails against it by perpetuating his original language, but by imposing a language that is ceaselessly modified, like an echo that would respond to the centuries with their own successive voices. The masterpieces do not keep up a sovereign monologue, but an invincible dialogue.

ITith the symbol of the echo answering the century with the century's own voice, we reach the heart of metamorphosis-the idea that each new culture re-creates the art of the past in terms of its own present. On a basis common to both the original and the inheriting culture, the latter imposes elements characteristic of its own epoch. Cultures totally isolated from one another in the Spenglerian sense could, at best, carry on monologues. Mal- 


\section{ANDRE MALRAUX: TRAGIC HUMANIST 177}

raux's reply is this concept of art maintaining a dialogue with time. As if to maintain the dialogue or echo pattern throughout The Voices of Silence, Malraux picks it up again on the last page and returns it to the problem of the real opponent of all art: destiny.

No death is invulnerable when confronted with a dialogue that has scarcely begun. Survival is not measured by duration; it is the form taken by one man's victory over destiny, and this form, when the man is dead, begins its unpredictable life. The victory that gave it life will give it a voice that its author didn't know it had.

Metamorphosis is obviously a central issue in The Metamorphosis of the Gods; and with one of the concise formulas that characterize this most recent of his books, Malraux sums it up by saying, "The metamorphosis of the past is first of all a metamorphosis of the way of looking at it." We are inclined to wonder if this vision of man's continually renewed cultural heritage was not born when Ling saw in the Occident a "creation ceaselessly renewed by the action of a world that is destined to action."

In spite of the reference to metamorphosis as the law of life for art and the triumphant tone of the lines from The Voices of Silence, Malraux remains true to his tragic vision even here, and the voyage of an art work through time is just as much a tragic adventure as any other aspect of his humanism and with the outcome just as much in doubt. The seeds of tragedy are present even in the statement of victory when Malraux writes that survival is not a matter of duration and the life of the art work is unpredictable. Even though a work continues to exist in historical time, it is to all intents and purposes dead so long as it is not in contact with the artist or culture for whom it has significance. It can be called back to life, "resurrected," only by this contact. Clearly we are here in a realm resembling, but not identical with, Proustian recall, in which a part of the past is brought back by a specific condition. For Malraux, as for Proust, the occur- 


\section{ANDRE MALRAUX: TRAGIC HUMANIST}

rence of this condition is, unfortunately, a matter of almost pure chance, "the tragic change" that Ling sees at the heart of European life. Physical destruction, always a possibility, would, of course, forever eliminate any chance of resurrection and metamorphosis. Apart from this, the contact between art of the past and a culture with enough in common with it to spark the resurrection also rests almost entirely on chance; hence the "uncertain eternity" of which Claude Vannec spoke. Faced with this intrusion of tragic uncertainty into what would otherwise have been the fullest human victory of all, Malraux reacts characteristically. "Metamorphosis is unpredictable?" he asked an audience. "Well, we are faced with a fundamental datum of civilization which is the unpredictability of renaissances, but I prefer an unpredictable world to a false one." In essence, this declaration is the same as the one in which A.D. swore to face squarely the unpleasant fact of absurdity. Total unpredictability is akin to absurdity and both have the same compensation: possibility. "The imaginary museum," he declares in The Voices of Silence, "is the suggestion of a vast possibility projected by the past." And, as always, with possibility comes freedom, for art also "tries to transform destiny into liberty."

For the artist this is, as we have seen, freedom from appearance and time. In art as in everything else, Malraux's thought moves toward an ever increasing synthesis; and these two elements, time and appearance, treated more or less separately in earlier works, are combined in The Metamorphosis of the Gods. The fusion had been hinted at in Ling's observation of the effort to "make time the prisoner of forms," but no further serious derelopment of the idea was to appear until his latest work. Here he makes the cycle complete by going back to the Orient for an illustration of his thesis, taking from Hindu mystic literature the story of an ascetic who sought from Vishnu the secret of Nirvana. Without bothering to retell the entire tale, we may say that the ascetic learns that time, which carries away all 


\section{ANDRE MALRAUX: TRAGIC HUMANIST 179}

things of this world, is as nothing to Vishnu. The twelve years in which the human character founds a family and a life only to see them swept away in a flood are "almost a half an hour" to the god. All that the ascetic had found and lost was only appearance. The lesson of the story, Malraux tells us, is that "everything subject to the reign of time is appearance." With this explanation of appearance in terms of time, Malraux provides the source from which flows all of The Metamorphosis of the Gods. The first volume deals with occidental art only through Van Eyck; but in the light cast by this new synthesis, Malraux's interpretations and the terminology applied to various types of art take on a new clarity. All real art attempts to penetrate appearance to something that is free, at least in a relative sense, from the reign of time. And everything of this earth, including its forms, is subject to time. So, it is true, are works of art, but they are more durable than any man and often more lasting than the forms of the earth. Thus, in making a conquest of appearance, the artist is also making one of time.

Consistent with Malraux's art theory as stated in earlier books, both the religious and the non-religious artist seek to penetrate the appearance of the world into some beyond that is free of time; and while the fusion of the two elements adds nothing vitally new to Malraux's interpretation of secular art, it enriches considerably his approach to the religious variety. The religious artist always has the feeling that beyond the time-ridden appearance of this world there is a "Truth" and this Truth is eternal, removed from time. Thus, by definition, the appearances of this world are unsuitable for representing the characteristics of the beyond that the artist is trying to convey. The gold background against which are set so many figures of Byzantine religious art is not there primarily for decorative effect but because such a background is not of this world. If it does not actually depict the world beyond, it does evoke it, removing the figures from the world 


\section{ANDRE MALRAUX: TRAGIC HUMANIST}

of appearance. Every truly great religious artist and style perform this function in one way or another.

They impose the presence of another world, not necessarily paradisiacal or infernal; not only the world after death, but a beyond that is present. For them, in various degrees, physical reality is appearance, and something else exists which is not appearance and not always called God. The accord of the eternal flow of man with that which governs or is unaware of him gives the artist his strength and his accent.

And later Malraux writes, "All of them tell us that throughout thousands of years the major object of artistic creation-which is not foreign to us, although it reaches us through metamorphosis-has been the revelation and maintenance of forms of Truth."

When one compares The Metamorphosis of the Gods with The Voices of Silence, one becomes aware that terms such as "destiny" and "sacré" are used much less generally in the later work. This is not an indication of any alteration in Malraux's own vision, which remains essentially unchanged, but a shift in the angle of his approach to artistic creation. Destiny and sacré as Malraux uses them in the earlier work are connotative of his world vision, hence they represent a point of view external to the artists themselves-one from which he can view all art in great synthesis. Malraux's concept of destiny was unknown to the artist whom he depicts as struggling against it; thus, the need in The Voices of Silence for the frequent insertion of explanatory phrases about what the artist was doing, "even if he was unaware of it." In The Metamorphosis of the Gods, however, Malraux is fundamentally concerned with what the artist actually feels he is doing. If destiny and the sacré, as such, are familiar to only a limited number of men, the feeling of appearance and the flow of time is common to almost all men, particularly artists. The term sacré is, therefore, modified to apply 


\section{ANDRE MALRAUX: TRAGIC HUMANIST 181}

to something that is not only truly transcendent but also to something that is viewed with reverence and awe, with emphasis on "awe."

With the artist himself as the starting point and the time-appearance relationship as the key to that against which he struggles, it becomes possible to demonstrate in terms of Malraux's aesthetics what the representatives of various schools and periods of art were trying to do. Malraux begins the main body of The Metamorphosis of the Gods with a consideration of Greek art of approximately the sixth century B.c. The art of its immediate predecessor had been dominated by the sacré and the idea of eternity, both of which, according to Malraux, the early Greeks threw off. This was an important break, for it made their art the earliest example of an art that did not "tend to create figures that equate the forms of life with the supreme truth that governs them." Other civilizations characterized by this absence of the sacré were the Hellenistic, the Roman, and the post-Renaissance European, although this is by no means to make their diverse arts identical in any other way. For the pre-Hellenistic Greeks, the separation from the sacré appears to have been more a matter of degree than of kind, a separation that seemingly had its origin in the fact that they did not feel so awed or dominated by their gods as had, for example, the Babylonians. That this is a matter of nuance is shown by Malraux's remark that Greece "never knew a true sacré." He adds significantly that it never knew a true profane either. From this he moves on to declare that the Greek artist was not, as is frequently believed, trying to make the gods resemble man, but precisely the opposite. Venus, as manifested in her statues, is not any more the depiction of a real woman than is Marianne, the symbol of France; the sculptor had gone beyond his model to manifest something else. For the Greek artist this something else was the divine which Greece had substituted for the sacré, and which Malraux defines as "that which is admirable." Of all the forces reflected in Greek art, only destiny was not admirable in any way, and only destiny has no temples and no statues. 


\section{ANDRE MALRAUX: TRAGIC HUMANIST}

Using the divine as his key, Malraux then turns to the clarification of what he had earlier called "one of the most equivocal ideas in aesthetics: that of beauty." All too often beauty has been approached from the idea of some harmony (probably Greek in inspiration) pleasing to the spectator. By beauty, Malraux says, the Greeks meant the invention of forms that express the divine. Although he develops this no further, it contains, by implication, a much more flexible interpretation of beauty, an interpretation based less upon the pleasure of the spectator than upon the intentions of the artist. The Greeks were probably more at one, in the sense of friendly intimacy, with their gods than have been any people before or since. The result of this, along with the passage from the sacré to the divine, is that the beauty which manifests divinity has a human rather than a superhuman quality. In the final analysis, the thing that most separates the statues of the gods from the models for them is that the former will not die. It is indicative of the difference between the sacré and the divine that the Hellenic Greeks, who turned toward the divine, spoke of immortality and not eternity. Eternity, as Malraux envisages it, is an attribute to the sacré.

With the passage into the Hellenistic period of Greek art, even such a minor transcendental as the divine disappeared from occidental art; and none was to reappear until the emergence of Christian art revived the sacré. In Malraux's interpretation, the Hellenistic artist was not concerned with going beyond appearance but simply in embellishing it. Here we enter a realm of art that Malraux admittedly views with a decided lack of sympathy, if not outright distrust. For what this art does is to consciously produce a world that does not exist and which is, therefore, fundamentally false. This Malraux refers to as "fictional" art, and it also comes under the category of what he calls art of "satiation" in The Voices of Silence. As compared to the religious artist who alters appearance in order to manifest some higher truth, the fictional artist depicts a nonexistent world whose main raison d'être appears to be that it is pleasing or agreeable to the spec- 


\section{ANDRE MALRAUX: TRAGIC HUMANIST 183}

tator. Although Malraux does not so state, it is implicit that here is where the concept of beauty begins to go astray; the mere idea of pleasure for the viewer can never be the inspiration of any truly great art.

Malraux had begun to make this point as early as The Temptation of the West. In one of A.D.'s letters, we find him writing of some works, for which Malraux will later express genuine admiration, that have been chosen because of "their will not to seduce" and because they are hardly touched with "the emotion that we like to call beauty." He goes on to mention the "need for a negative classicism, based almost entirely on a lucid horror of seduction." Here Malraux's thoughts on art again reveal their affinity with those of Nietzsche. "From the nature of art as it is usually conceived according to the single category of appearance and beauty," the latter wrote in The Birth of Tragedy, "the tragic cannot honestly be deduced at all." In the light of these lines we can see the basic reason why Malraux reacts so adversely to this "fictional" art that aims to "seduce" the viewer. Malraux's tragic vision derives from his consciousness of the universe, and all real art, tragic or not, begins, as we have seen, with the artist's fundamental feeling about the universe. Far from being so based, fictional art creates a false universe that attempts to dull consciousness of the real one. To reject this "agreeable" universe in favor of the one that exists is, in Malraux's terms, "to be Rembrandt and not Raphael."

If Malraux views Hellenistic art with something approaching disdain, he has a hard time calling that of pre-Christian Rome art at all. He has, in fact, noted at one point that Rome had no art. The busts of emperors, Rome's most frequent effort in the area of the plastic arts, he views as an attempt simply to copy appearance. And lest there be any question that he has changed his view that the true artist never submits to the world, he writes in The Metamorphosis of the Gods that works "exclusively subjected to appearance" or "intended exclusively for the pleasure of the spectator" are as different from a work of art as the most brilliant recitation is from 


\section{ANDRE MALRAUX: TRAGIC HUMANIST}

a poem. Absolute realism, such as is encountered in the imperial busts and statues, is "using the means of art for other purposes."

After the non-art of imperial Rome came the rebirth of the sacré in the form of Christianity and with it the great arts-Romanesque, Byzantine, Gothic, and so on. Treatment of these makes up by far the largest part of the book and is far too detailed for discussion here. Suffice it to say that the different styles reflect different aspects of the Christian belief and different feelings about man's relationship to the Trinity, the saints, and other elements of the religion. Here Malraux makes some subtle and perceptive interpretations that the Catholic critic André Rousseaux has said are among the finest appreciations of Christian art ever written. The first volume also deals with early Flemish painters, in particular Van Eyck, and ends with the reintroduction of the "unreal" and "nonexistent" by Italian painters.

Many of Van Eyck's paintings, in particular the secular works such as the portrait of Jean de Leeuw, are ordinarily considered "realistic," and the great "realists," including Vermeer whom he admires, provide Malraux with one of the knottiest problems raised by his aesthetics. If the artist is said never to submit to appearance, what is he to do with the great who are usually regarded as having tried to reproduce it? Obviously Malraux does not view the "realism" of Van Eyck and Vermeer in the same way as he does that of the Roman busts. But, faced with paintings like those of the two artists in question, Malraux is forced to accept that, at least in part, they reveal an effort to "copy the spectacles" or, in other words, to reflect appearance. This, however, is not the only tendency that he finds in them. True, they contain a reference to appearance, but they also show "a reference, sometimes clear, sometimes enigmatic, to something besides appearance." When he writes at another point that the best of these works have "reflections of mortal appearance, but also those of another world," he indicates his path out of the dilemma, for the other world of which he speaks is that of art itself. As an example he gives Van Eyck's use of shadow, 


\section{ANDRE MALRAUX: TRAGIC HUMANIST 185}

which is not the shadow of appearance and which, Malraux declares, makes the figures set against it attain the realm of the non-temporal. In all great realistic art there is something that accomplishes this end in one way or another. It is the presence of this other "something," admittedly often enigmatic in nature, that permits Malraux to accept as genuine art those great works that attempt to give the illusion of reality. His adherence to the thesis that no artist of genius accepts physical reality is indicated when he sums up his position on the type of art under discussion:

A Balzac novel resembles reality, it does not coincide with it. If it did so, it would act upon us in another way and we would cease to admire it. The masters of the painting that will be called realistic paint pictures that resemble scenes, but it is not this resemblance that we admire. They also paint what we do admire: that which distinguishes their painting from the scene it resembles. They show their skill by the resemblance and their genius by the separation.

To put this in terms of Malraux's earlier remarks on the same subject: the realists are artisans to the degree that they copy appearance, artists to the degree they go beyond it. When art is viewed in this fashion, it becomes "an inexhaustible music for which the world of appearance is only the inexhaustible score."

All of this has a definite application to the art of Malraux's novels, for he creates his works in terms of his aesthetic vision. Inasmuch as his fiction is drawn almost entirely from his experiences in the world and the events of our day, much critical effort has been expended on determining just how accurately he depicts these experiences, this world, and these events. The answer, of course, to employ the terms Malraux uses with respect to Balzac, is that his novels resemble reality but do not coincide with it. This was already implicit in Malraux's reply to Trotsky's accusation that The Conquerors was not historically accurate. "The optics of the novelist are not 


\section{ANDRE MALRAUX: TRAGIC HUMANIST}

those of the historian," was his rejoinder. He could not have said otherwise and still have remained true to his concept of art. Malraux writes tragedy, and the data of reality are altered to contribute to this end. If the jungles of Indo-China are neither so deadly nor so isolated as those of The Royal Way, he has added to the menace and the loneliness because it intensifies the atmosphere of tragedy. If the time schedule and the persons present at the Shanghai insurrection are not the same in $M a n$ 's Fate as they were in reality, it is for the same reason. In his case, as in that of Aeschylus, appearance and reality are only the raw materials for the creation of tragic art.

For, as Malraux envisages it, art is not "a corner of the world seen through a temperament," but the world seen in terms of an over-all world vision; and, in his Preface to Sumer, he suggests that our most fundamental relationship to art is metaphysical. The degree to which his vision determines both his own art and his interpretation of that of others was made evident when he wrote, "The secret of the greatest art is ever the same: to use human means to burst the bonds of the human condition." 


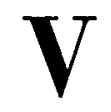

\section{THE FUNDAMENTAL, OR THE STRUGGLE WITH THE EARTH}

Thus goeth the body through history, a becomer and a fighter. Remain true to the earth, my brethren, with the power of your virtue!

-Nietzsche, "Thus Spake Zarathustra"

My father told me: "You must never turn away from the earth."

- "The Conquerors" 

IF IT CAN BE TRULY SAID that in the last analysis Malraux's humanism is an interrogation on man, it can be stated with equal truth that, more than any other of his works, The Walnut Trees of Altenburg concentrates on a single crucial aspect of this questioning. The Altenburg colloquy poses and tries to answer the query in an intellectual fashion; the rest of the novel seeks a reply by other paths. The specific nature of the problem is made clear when Walter Berger hands his brother Vincent a paper on which is written: "Does there exist a datum upon which the idea of man can be based?" or as it is put elsewhere, "Does the notion of man make sense?"

Within the framework of the colloquy itself, the matter is precipitated by the ethnologist Mollberg, who for several years had been trying to formulate "a rigorously continuous idea of man, a structure of the human adventure." His effort is admittedly a failure, and he swings to the opposite, Spenglerian extreme of postulating that there is no linking or communicating element, no permanent factor-a negativism that had an early predecessor in Malraux's works when Ling flatly denied the existence of a permanent element in man. The collapse of Mollberg's original project leads him to pose the problem in such an acute and absolute fashion that to answer him is to a large degree to refute Spengler. The lines in which the ethnologist rejects the idea of a common element in man contain the most direct statement of Spengler's position to be found in Malraux's writing, and as such they merit being quoted in detail. Like Ferral's cogent defense 


\section{ANDRE MALRAUX: TRAGIC HUMANIST}

of his attitudes, they typify Malraux's tendency to give eloquent expression to the ideas that most seriously contradict his own.

If the mental structures disappear without return like the plesiosaurus and civilizations follow each other only to cast man into the bottomless pit of nothingness, if the human adventure can be maintained only at the price of an implacable metamorphosis, it makes little difference if men transmit their concepts and their techniques for a few centuries. For man is a random accident and the world is essentially made up of forgetfulness.

One is struck by at least two things on reading this passage. Although Mollberg does not believe in any linking element, his words show that he conceives of something resembling Malraux's metamorphosis, itself a direct contradiction of Mollberg's conclusion. Then too, the passage as a whole, with slight modification, seems to echo the same tragic world vision upon which Malraux bases his humanism. It depicts the burden which, he says, Western man has shouldered as he moves endlessly into the night. This striking similarity has led many critics to assume that Mollberg speaks for Malraux. To accept this, however, is to overlook the fact that Mollberg's evaluation of this picture, "it makes little difference," would deny a real validity to tragedy itself, to the will that converts tragic vision into tragic art. Such a position is obviously inconsistent with Malraux's own. To situate Mollberg's attitude accurately with respect to Malraux's, it is only necessary to view his value judgment on the human adventure in terms of the one made by Garine on human life: from the cosmic viewpoint, it may be of no importance; from the human one, it is all-important. The implacable metamorphosis, which (by Mollberg's own admission) maintains this adventure, provides the key to refutation of his idea and at the same time attests the vital importance of continuing the human struggle which he had dismissed out of hand. Men do not struggle endlessly for something that is of no importance to them. 


\section{ANDRE MALRAUX: TRAGIC HUMANIST 191}

When the subject of the colloquy is changed to the "permanence and metamorphosis of man," the path is opened to an affirmative answer to the original question. Mollberg is willing to concede that one could conceive of "a permanence of man," but, true to his central thesis, he insists that it would be a permanence in nothingness (néant). Once again this is not inconsistent with Malraux's own position if the latter is viewed from only one angle, that of the universe. But there is another angle, the human. Within the colloquy itself, this is represented only by Vincent Berger, who replies that it is also possible to conceive of a permanence of man in the fundamental, a concept rejected by the ethnologist. The German's position in this matter contains a core of nihilism common also to much fascist thought, ideas with which the events of the past several years put Malraux in intimate contact. His experiences with Hitler's Germany and the Spanish Civil War clearly demonstrated to him the dangerous, anti-human potentialities of such a view of man. We are, therefore, safe in conjecturing that, since he felt the menace to be so serious that its political manifestations should be opposed with armed force, he would be unlikely to endorse one of their basic philosophic premises. While the ideas of a fundamental element present in all men and a universal human dignity may not be identical, they are so closely interwoven as to be nearly inseparable. To reject the former would mean that Malraux was putting his entire ethics in jeopardy. His cognizance of the crucial nature of this problem is shown when, in Man's Hope, he has the elder Alvear gravely warn Scali that "the age of the fundamental is beginning anew" and that "reason must be re-established on new bases." We can accept Alvear as speaking for the author here because Malraux made essentially the same observation in his UNESCo lecture.

The complicating fact is that, during the discussions at Altenburg Mollberg defeats all the intellectual formulas offered by the other participants, including Vineent Berger, as refutations of his Spenglerian hypothesis. Taking some carved walnut statues in the Altenburg priory as his symbol, he 


\section{ANDRE MALRAUX: TRAGIC HUMANIST}

says that they derive from no fundamental walnut, only from individual logs. Transferring this to the human level, he claims that the truth about man is the animal in him and makes his rejection of the fundamental man categorical:

Fundamental man is a myth, a dream of intellectuals with respect to peasants. Think a little about the fundamental worker. Do you think that for the peasant the world isn't made up of forgetfulness? Those who have learned nothing have nothing to forget. I know what a wise peasant is, but he isn't the fundamental man. There exists no fundamental man augmented, according to his time, by what he thinks and believes. There is the man who thinks and believes, or nothing.

Vincent Berger, defeated on the intellectual plane by Mollberg's arguments but feeling instinctively that there is an answer to them, goes for a walk in the woods near the priory. Contemplating the trees, he begins to have a growing awarness, a conscience, of an affirmative response.

He had reached the large trees; pines already dark with night, a still transparent drop of water at the end of each needle; lindens noisy with sparrows. The handsomest trees were the two walnuts. He remembered the statues in the library.

The fullness of the centuries-old trees emanated from their mass, but the effort by means of which the twisted branches emerged from the trunks, the spreading of the dark leaves of this wood, so heavy and so old that it seemed to dig itself into the earth and not tear itself away from it, imposed the idea both of endless will and of metamorphosis. Between them the hills sloped away to the Rhine. They framed the cathedral of Strasbourg far off in the lovely twilight, just as so many other trunks frame so many other cathedrals in the fields of the Occident. This spire, like the prayer of an amputee, and all the human patience and work spread out in waves of vines as far as the river were only the evening décor surrounding the ancient growth of living wood, the two thick, knotty trees that extracted the forces 


\section{ANDRE MALRAUX: TRAGIC HUMANIST 193}

of the earth in order to deploy them as branches. The sun, now very low, pushed their shadows to the other side of the valley. My father thought of the two saints, of the Atlas. The twisted wood of these walnut trees, instead of supporting the burden of the world, spread out in an eternal life against the sky their shining leaves, their almost ripe fruit, and all their solemn mass above the young shoots and the dead nuts of the past winter. "Civilizations or the animal, like the statues or the logs. "Between the statues and the $\operatorname{logs}$, there were the trees, and their design as obscure as that of life itself. And the Atlas, and the face of Saint Mark, ravaged by Gothic fervor, were lost, as was culture, as was the mind, as was all that my father had just heard-buried in the shadow of this indulgent statue sculptured by the forces of the earth, which the sun, now at hilltop level, spread over the anguish of men as far as the horizon.

This passage, from which the novel takes its title, and which Frohock has accurately called one of the most important in the book, obviously has more than one function, so much more that virtually everything in the rest of the novel relates to it either directly or indirectly. On the literal plane, it is clearly intended as a direct refutation of Mollberg's separation of the walnut logs and the statues as having nothing fundamental in common. The link, vital in both senses of the word, is the living tree without which there could be neither logs nor statues-the tree that struggles endlessly to obtain life itself from the earth, a life that is in turn put forth in the branches, shoots, leaves, and fruit.

This reply to Mollberg's symbol also contains, by implication, the argument for the existence of an element that is present in all civilizations and cultures and that is symbolized by the walnut trees: the struggle with the earth to maintain life itself. Like the shape of the tree, like its leaves and fruit, this life can and does take a multitude of forms, those of the limitless variety of individual men as well as those of different civilizations. But, as with the tree, none of these variations could exist without the fundamental 


\section{ANDRE MALRAUX: TRAGIC HUMANIST}

struggle. Hence, Vincent Berger's feeling that all the talk concerning the mind, various cultures, and the like to which he had been listening was buried in the shadow of these magnificent trees.

Both the language of the passage-with its reference to metamorphosis, sculpture, and statues-and its vision of the earth's conversion into new forms, make it evident that, for Malraux, artistic creation and the basic human effort to wrest mankind's needs from the earth are but different phases of the same struggle. And both are common to all civilizations, no matter how they are separated by space or time; together they constitute Malraux's answer to Spengler.

The language of the passage is highly poetic and subject to varied interpretations. Some critics, as Frohock has noted, have completely misunderstood it; and he himself, while feeling that it dealt with, and answered, Malraux's search for the fundamental, reached the conclusion that fraternity was the answer. To the degree that we are dealing with the fraternity of a common struggle, this is accurate, but it leaves unanswered the question of the nature of the struggle, the source of the fraternity. Although neither the passage nor the rest of the novel provides a clear-cut statement that the trees symbolize the fundamental human struggle, the larger context of his work provides considerable evidence that such was the intention. In the course of The Voices of Silence, Malraux twice uses the tree as a symbol for man and his struggle, stating at one point that our present consciousness of man in history is best symbolized by the seed that becomes a tree. This not only conveys the idea of something that converts the forces of the earth into its own life and growth, it also contradicts Mollberg's statement that there is no fundamental man augmented in the passage of time. The final pages of The Voices of Silence sum up man's subjection of the earth with the observation that the man suggested by all this is both an actor in the vastest of all adventures "and also the deep 


\section{ANDRE MALRAUX: TRAGIC HUMANIST 195}

roots from which spring shoots that sometimes intermingle and are sometimes unaware of one another."

Nor is the precise idea of the struggle with the earth without precedent in Malraux's works. It begins to take form in The Conquerors, when Garine declares that "those who try to leave the earth soon perceive that it clings to their fingers." With these words we are introduced to an element that gives tragic intensity to this struggle. The earth fights back, moving endlessly to swallow up the results of man's effort to convert it to his use. The slightest lapse in the human effort results in a reconquest by nature. The Royal Way furnishes a dramatic example of this. The ruins being sought have long since been taken over by the jungle, and the jungle continuously battles all efforts to reach and rescue the sculptures it has made captive. Rarely in fiction has nature been made to appear more malignant and menacing than in this novel. With the single exception of the incident of the walnut trees, there is no sympathetic depiction of nature in Malraux's fiction. In one way or another, it is always an obstacle to man.

The idea of the struggle with the earth becomes specific in Man's Fate. Pei, after fleeing Chiang Kai-shek's repression, has gone to work in a Russian factory, which he visualizes as filling the role formerly played by churches. Describing what is taking place in the factory, he writes to Gisors that "instead of gods, it is human force in battle with the earth." Gisors' reaction to this is: "Yes, the value of men can perhaps only lie in what they have transformed." The parallel between the artistic struggle and the fundamental one is already clear. With Days of Wrath this fundamental effort is further exalted and generalized with the declaration that "what is sacred in man is the assault against the earth the whole stubborn world of men, the combat against the earth that is inexhaustibly nourished by the dead," a declaration whose tone and content lead one to wonder how familiar its author was with Alfred de Vigny's La Maison du Berger. At 


\section{ANDRE MALRAUX: TRAGIC HUMANIST}

this same period, he was telling the audience at a cultural congress that the true adversary of man is the world. The relentless nature of the conflict is dramatized in Man's Hope when a peasant, "his face refined by mystery," tells a group of the loyalist fighters,

The principal enemy of man, gentlemen, is the forest. It is stronger than we, stronger than the Republic, stronger than the revolution, stronger than war. If man stopped fighting it, in less than sixty years the forest would recover Europe. It would be here, in the street, in the open houses, with its branches in the windows, with pianos in its roots. And that would be that.

In The Voices of Silence this becomes "the rivalry between the earth and the works of man," a rivalry that, like all the other struggles in Malraux's tragic humanism, mankind will probably eventually lose. Virtually the final words in The Voices tell us that "without doubt, someday, before the expanses, arid or reconquered by the forest, no one will divine the forms that human intelligence had imposed on the earth." Reflected against such a sounding board, the earlier remark about the sacredness of this struggle achieves its full resonance. The effort to carry on against such odds must be of heroic stature, must have the endless will of which the walnut trees made Vincent Berger aware.

The revelation of the fundamental is so important in The Walnut Trees of Altenburg that it can be said to give the novel its form. Each of the five sections deals with a different level of awareness of the fundamental. The first part, which chronologically follows the other four, finds Vincent Berger's son in as full a possession of the secret as anyone ever attains. Wounded and a prisoner in the camp at Chartres, he is in direct and intimate contact with a vast number of half-starved prisoners from all walks of life. Their conversation reveals that the majority of them are from social levels where existence is a matter of continuous struggle. As soon as hunger and the growth of beards have stripped away the veneer of contemporary civiliza- 


\section{ANDRE MALRAUX: TRAGIC HUMANIST 197}

tion, young Berger is struck by the degree to which the prisoners resemble men of the Middle Ages. He finds in them a centuries-old memory of plagues and also the same tenacious will with which men have always survived plague and famine.

In the second part, Vincent Berger is granted a premonitory glimmer of the fundamental secret before the Altenburg discussions begin. It is made clear that he, as was the case with his son, is in contact with ordinary people, the citizens of Reichbach, who are just beginning to go to their daily work. Description of them as being "alike and different as the leaves of trees" prepares the way for the symbol of the tree that follows. A remark concerning "the infinite multiplicity of the banal Reichbach countryside" reinforces the same idea of combined diversity and unity in this scene of man and the daily business of living. From this there "seems to rise" to Vincent Berger a sense of the secret of "the human adventure, the earth"- a secret he feels is less one of death than of life. The tone and wording of the passage make it evident that this is a prelude to his experience outside the priory. A prelude only, however, for the question of the fundamental has not yet been formulated; nor does this brief moment of awareness really tell Berger anything about the nature of the secret. Further revelation must wait until the discussion at the colloquy challenges the existence of this thing, which he has thus far felt only vaguely. The walnut-tree episode provides him with a symbolic confirmation of the fundamental but still does not make its nature clear to him. Although he now feels strongly that there is a human unity, his experience with the failure of the Touran movement, which had tried to unify a segment of humanity, stands in the way of his confirmation.

This confirmation, as Professor Frohock has noted, is furnished by the incident of the gas attack on the Russian front. Here again Malraux is careful to situate his protagonist in the midst of ordinary people-peasants, workers, and the like-whose talk, as recorded in the novel, reflects the 


\section{ANDRE MALRAUX: TRAGIC HUMANIST}

eternal, basic preoccupations of those who must perforce remain in intimate contact with the struggle for existence. As are their counterparts in the prison camp at Chartres, they are skeptical of the exalted reasons usually given for waging war and killing other men. When, in the course of the attack, German infantrymen violate their officer's commands in order to save the lives of their Russian enemies, Berger has his fullest revelation. The lines drawn by nationality and differences in civilization are obliterated as men from one country struggle to preserve the lives of those of another. The spectacle immediately makes Berger think of Altenburg and the walnut groves, and the chaos of the scene is compared to a forest. The timespanning quality, conveyed at the Chartres camp by young Berger's awareness of the medieval aspect in the men's faces, is here suggested by the observation that "it was as if the blanket of gas, instead of uncovering Russians, had uncovered the cadavers of men from the quaternary epoch."

The action of the Germans is, of course, a fraternal one and is so called in the novel, a factor that doubtless contributes to Frohock's conclusion that fraternity itself is the fundamental quality of man. But, as the passage states, "it was a question of a movement that was profound in a different way, one in which fraternity and anguish were inextricably intermingled, a movement that had come from very far back in time. " ${ }^{1}$ On the most basic level, we are here dealing with man's struggle for continued existence against whatever forces, the earth or his own demon, menace it. Here again the unity of Malraux's thought becomes evident as the fundamental and ethical aspects of his humanism join.

The effect on Vincent Berger is "a mystery that did not reveal its secret, only its presence-so simple and so despotic that it cast into nothingness all thought connected with it." This is as far as Berger carries the problem of

- And far back in Malraux, we have already noted that Tchen in Man's Fate performs an action paralleling that of the German soldiers. 


\section{ANDRE MALRAUX: TRAGIC HUMANIST 199}

the fundamental. He is caught by the spirit of the rescue movement, joins it, is gassed, and dies. The heritage of his experience is passed on to his son in the form of notes, significantly titled "My Encounters with Man."

War again provides the setting when the younger Berger receives the final revelation. The crucial episode begins when Berger, along with a crew of three other men, is driving a tank toward the German lines during a desperate French assault. Few situations bring men into more intimate contact than being in the same tank crew, and Malraux takes pains to indicate that, except for Berger, the crew came from the struggling levels of society. Berger, the intellectual, is more closely involved with the people than even his father was, and under very extreme and tense circumstances. In its nocturnal movement toward the German lines, the tank falls into an antitank ditch. Then begins a period of agonizing fear. Escape from these traps is virtually impossible, and they are certain that the German artillery has them pinpointed. Terror strips the differences from the man and Berger screams with fear like the rest. To leave the tank would be suicide, and it is only a matter of time before the shells will begin to fall. The struggle is one for life itself, and the instinct for self-preservation drives the crew to an immense effort to extract the tank from the trap. By a stroke of luck that borders on the miraculous, they succeed. Young Berger has lived through the most intense and vital experience of the entire novel, the experience that leads directly to his grasp of the secret of the fundamental. He has come back to life from the very edge of death; he has seen and lived the struggle of man to continue living. It is of at least secondary significance that it was the earth, in the form of the ditch, against which the battle was really waged.

The men take the tank to an abandoned farm village, camouflage it, and get what rest they can. With the dawn of the following day, Berger increasingly feels that he is really seeing life for the first time. The setting is important. All about him are the things the peasants have left behind in 
their flight from the war. These abandoned items are ordinary in the extreme: clothes, pins, rakes, chickens unaffected by the war, sprinkling cans. The last in particular brings Berger to an awareness of the significance of the rebirth he is undergoing. "Suddenly," he notes, "it seemed to me that man had come from the depths of time just to invent a sprinkling can." The analogy with the struggle against the earth is clear and is strengthened by Berger's further observations: "How all these forms are suited to the earth"; and "There is nothing here that does not bear the mark of man." The earth's struggle to obliterate all human effort is suggested by a reference to "voracious brambles that will, perhaps, have covered over everything within a year." The scene is given a timeless quality: the barns are gothic and the dawn a biblical one in which "centuries crowd each other." The climactic awareness comes when the men discover two old peasants who have chosen to remain rather than abandon their farm. For them, the war is just a part of the unending series of difficulties against which they must struggle to wrest life from the earth. They will wait it out as man has always done. The peasant smiles ironically at the whole situation, even at death, for he knows that mankind will continue in spite of everything. Berger now sees his experience of the past night as part of the universal human fight for existence. "I know now," he concludes, "the meaning of the ancient myths of beings who are wrested from the dead. I scarcely remember the terror, for what I bear within me is a simple and sacred secret." A line from Saturn gives a strong indication of both the secret and the myths Berger meant: "It remains true that the harvests are no less eternal than the scourges; Cybele no less so than Persephone."

Mollberg, who flatly denied that the peasant could be the fundamental man, is refuted in the last analysis by a passage that presents the peasant as just that. Because of his intimate and continuous contact with the struggle for existence, the peasant makes an excellent symbol for the fundamental, as does the walnut tree-and for much the same reason. 


\section{ANDRE MALRAUX: TRAGIC HUMANIST 201}

Nevertheless, there is an indication that Malraux intends to give a broader meaning to the concept of the fundamental. Although heavy emphasis is placed upon the fact that at the time of awareness both Vincent Berger and his son are in contact with ordinary working people, these people are not, with the exception of those in the final episode, primarily peasants. They are people whom circumstances force to remain close to the basic struggle for existence. And one notes that, in the scene depicting the gas attack, although Vincent Berger may have felt a sense of exaltation at the fraternal action he is witnessing, it is something very much akin to fear and horror that inspires the action: it is a reaction against a threat to human existence itself. Fear is also the predominant note inside the trapped tank. What Malraux is demonstrating in these scenes is that there are a number of emotions and reactions common to men of all social levels, all times, and all civilizations. They are the result of experiences fundamentally and universally related to the business of life no matter where or when it is lived. In Man's Hope, the first novel to pose the problem of the fundamental, it is said of Shade, the newspaperman, that "he no longer attached any importance to anything except what he called idiocy or animality, that is to say, the fundamental life: suffering, love, humiliation, innocence." Not too long before, Malraux himself was telling an audience, "As for me, I gladly accept the idea of seeing the communion of all men reborn in the fundamental domain of human emotions." This domain, intimately and inextricably woven into the fabric of human existence, is everywhere and always identical. "This profound life," A.D. had written to Ling, "is also the most rudimentary."

All this is closely related to the reason why the Altenburg intellectuals failed to grasp this unity whereas Berger and his son succeeded; and in Malraux's philosophy, this reason is as important as the discovery of the fundamental. In overly simplified terms we may say that Mollberg and the others failed because they made a purely intellectual approach to a prob- 
lem that does not admit of an intellectual solution. Consideration of the episodes in which the answer is progressively revealed shows that increasing revelation corresponds to increasing intensity of experience and involvement. At Reichbach, Vincent Berger has no real connection with the scene around him. At Altenburg, he is involved to the extent that the idea of human unity so dear to him is threatened by Mollberg's arguments. On the Russian front, his contact is closer, but he does not become really involved until he himself attempts to rescue a Russian soldier. His son's experience is one of fighting for his life. His illumination the following morning is an example of the transformation of experience into consciousness. Experience remains the only true source of basic knowledge about man. As Gisors noted, "To try to know men by means of intelligence is a vain effort to bypass time."

Here again the remarkable unity between Malraux's life and work becomes evident. With the possible exception of a few details, the younger Berger's World War II experience is that of Malraux himself. As does his creation, Malraux fought in the tank corps, was wounded, and taken prisoner. The episode of the tank attack has the ring of true experience. Only one who has undergone it knows that continued movement toward the enemy is not so much a matter of courage as reflex action, and that it is characterized by a specific, yet undefined, emotion. Dozens of passages have been written describing artillery barrages, but few if any have noted that when the guns are zeroed in, a soldier does not listen for the detonation of the shell but for the blast from the cannon which announces that potential death is on the way. Service in a combat arm, such as the infantry or the armored force, would necessarily have brought Malraux into close contact with men of every social level. There is good reason to believe that the incident of the trapped tank corresponds very closely to a similar experience in Malraux's own life.

The failure of the intellectual approach to discern the fundamental 


\section{ANDRE MALRAUX: TRAGIC HUMANIST 203}

quality of man, as contrasted with the success in finding it that is attained through experience, does not imply a condemnation of the intellect per se as a means to knowledge. Both of the Bergers are intellectuals as well as men of action; they are excellent examples of the protagonist Malraux describes in the Postface to The Conquerors: "A type of hero in whom are united an aptitude for action, culture, and lucidity." Rather, the judgment is against what might be called the "pure intellectual," against intellectualism completely divorced from real human experience. As one of the characters in Man's Hope put it: "In order to talk about love to those in love, it does no good to have made an inquiry on love, you have to have been in love yourself." In the basic, universal areas of human experience the purely rational, objective approach is insufficient. This can be taken as a second symbolic meaning of the observation that the walnut trees "seemed to bury themselves in the earth, and not tear away from it." 2 Intellection on the mystery of man is valid, according to Malraux, but only after immersion in the basic experience of existence. This attitude is implicit in a remark concerning American writers attributed to Malraux by Henri Peyre in his Contemporary French Novel. The gist of Malraux's observation was that American writers have a good grasp of the fundamental in man, but do not intellectualize on it sufficiently.

It is, therefore, a lack of human experience that prevents the Altenburg intellectuals from discovering the fundamental. They are simply too far removed from the life that comprises it. It is ironic that Mollberg should speak of the fundamental man as a "dream of intellectuals" when the main defect to his own approach is that it is too purely intellectual. No less

"A third meaning, equally valid in terms of Malraux's vision, is that it constitutes an injunction to devote one's self to life on this earth rather than to a promise of an afterlife. In this, Malraux would be once more striking a Nietzschean note: "I love those who do not seek a reason beyond the stars for being sacrificed, but sacrifice themselves to the earth." 
significant is the fact that he spoke only of men who think and believe and not of men who feel, struggle, and live. With such a one-sided view, he could not see the living wood as the connection between the carved walnut statues and the logs. This parallels the warning that Malraux had issued not many years earlier to a congress of Soviet writers. He reacted to their concept that the literature growing out of a political doctrine should express or incarnate that doctrine by drawing their attention to the fact that between any doctrine and any literature there are living men.

Yet another point concerning the collapse of Mollberg's original attempt to give "a structure to the human adventure" should be made. Every time something about this adventure is revealed to either of the Bergers, its formless quality, the fact that it is a mystery whose nature cannot be clearly defined but only experienced, is strongly emphasized. At no point does Malraux suggest that the adventure can be formulated in rational terms. Structure and adventure, in fact, for Malraux, constitute a contradiction in terms. Mollberg is seeking what Nietzsche called "the theoretical world view," which is in direct conflict with Nietzsche's and Malraux's "tragic world view." And Malraux's vision of the human adventure is consistent with his tragic humanism. Neither its form nor its direction can be precisely predicted. For this reason the tree whose form can likewise not be specifically delineated emerges as one of the best of all possible symbols for the fundamental human adventure.

As with all the key aspects of Malraux's thought, the fundamental struggle with earth, the element common to all humanity, reduces to a matter of conscience-the conscience, in this case, of the unifying element in humanity derived from the experience of being an active part of the human world. For Malraux, there is still validity in Ling's assertion that "to know the world is no more to make a system of it, than to know love is to analyze love. To know the world is to be intensely conscious of it." Malraux said in a personal letter, "I seek less a new image of man than a 


\section{ANDRE MALRAUX: TRAGIC HUMANIST 205}

new consciousness." An image or structure is fixed or at least predictable. Man in Malraux's vision is becoming-what?

Consciousness of a fundamental underlying link in the human adventure is a vital necessity for any real humanist, especially for one such as Malraux who does not visualize humanity as moving toward any predetermined goal. It is only after Malraux attains this consciousness that he begins to talk in terms of a universal humanism. He has found a link between all men in the struggle for continued existence. Ling had said that everything could be attempted by a culture whose elements were linked only by their presence in man. His words laid the keel for the "culture of great navigators." With the conscience of the fundamental, it set sail. 



\section{VI}

\section{THE PROBLEM OF THE ABSOLUTE}

Never yet did truth cling to the arm of an absolute one.

-Nietzsche, "Thus Spake Zarathustra"

What is in the process of disappearing from the Occident is the absolute.

- "The Voices of Silence" 

Throughour everything André Malraux has written on art runs the theme of mankind's need for a transcendant, something above and beyond himself, something to provide answers to his eternal questions concerning his nature and destiny, something to absorb him so completely emotionally and spiritually that he will be taken out of himself-in short, an absolute. Religion has most often fulfilled, or attempted to fulfill, this need; and few men have written more eloquently than Malraux about the great art produced by men oriented toward this absolute. His active career has brought him into close contact with men serving another kind: the political. His novels depict more than one man who risks torture and death on behalf of ideals professed by the political absolute; and in his works there is ample indication of his knowledge that reason, science, and man himself have at some time and for some people played the role of an absolute. The humanism that he himself exemplifies is man-centered, but since it culminates in a question rather than an affirmation, it does not meet the most pressing requirement of the absolute.

Few men, however, have shown more acute awareness of the negative aspect of the absolute; for it is, in Malraux's view, the same as action, a two-edged sword. It can and has led to the majority of man's greatest artistic creations, and within a group that is directed toward the same absolute, it may and often does lead to a profound communion or fraternity. This is demonstrably true in the case of a political or religious faith during the period when it is struggling to establish itself. Unfortunately, 
however, the effect is just the opposite where the feeling toward anyone outside the group is concerned. All too often it is characteristic of those who are absorbed with a given absolute to view those who are not with attitudes ranging from indifference through intolerance and bigotry to outright hatred. At the very least, there is no really significant communication with outsiders. "A religion unites men to the degree that it makes them fellow men," Malraux wrote in L'homme et le fantôme, "but most often this fellow man is limited to co-religionaries." The same is true of political absolutes. For a humanist, one of whose major preoccupations is the battle against human solitude and isolation, this aspect of the absolute presents a serious problem, a problem he must deal with on both the individual and group levels.

There are, in Malraux's works, three outstanding examples of individuals obsessed with a desire for a personal absolute: T. E. Lawrence and the two terrorists Hong and Tchen. His study of Lawrence is incomplete, and Hong is only a preliminary sketch for Tchen, who is perhaps the most complex character Malraux has created. Tehen is far too complicated to be explained simply in terms of an obsession with the absolute, but this is, nonetheless, his dominant characteristic. Religious education had put Tchen in contact with Christianity and had stimulated in him a need for some absolute. This need was never fulfilled. For Tchen, life became a continuous striving to attain some absolute, a striving raised to the intensity of anguish because he did not know precisely what he was seeking. Inevitably, the absolute would have to produce for him a sensation intense enough to erase the anguish. The rarity of such a sensation converted Tchen's obsession into a vicious circle, and the circle is narrowed because the meditation necessary for the comprehension of an absolute of any real profundity is directly contradictory to Tchen's nature. Using terms that Malraux employs in another context, we may say that the only absolute capable of satisfying Tchen will fall within the domain of "satiation" 


\section{ANDRE MALRAUX: TRAGIC HUMANIST 211}

rather than that of "true values." Kyo's reaction to Tchen summarizes his situation: "He [Kyo] had listened to his father enough to know that anyone who seeks the absolute so avidly finds it only in sensation. Thirst for the absolute, thirst for immortality, therefore fear of dying. Tchen should have been a coward; but, like every mystic, he felt that his absolute could be seized only for an instant."

It is obvious that a man thus driven cannot fit into any social group, for the very necessity for a personal absolute cuts him off from his fellows. None of the three absolute-haunted men with whom Malraux deals was able to maintain a relationship of real significance with someone else. In this respect a letter by Lawrence, cited by Malraux in N'était-ce donc que cela?, applies equally well to Tchen: "Somewhere there is an absolute, and it is the only thing that counts. I am not finding it. Hence this impression of a purposeless existence." In spite of anything that Tchen may have said to the contrary, his major reason for attachment to the revolution was not that he felt he was one with its ideals or its members, but that violence and combat at least partially satisfied his need for intense sensation; as Malraux wrote in The Voices of Silence, "If combat does not replace the absolute, it permits one to forget it."

Tchen recognizes that combat is one of the strongest of all bonds, but even the most intense variety is insufficient to link him with those about him. He is led to wonder, "Is blood itself in vain?": and to conclude, "I

am extraordinarily alone." His situation is bad enough even when he is engaged in the violent action that is part of revolution; when the revolution ends, or enters a quiescent period, adherence to it inevitably becomes intolerable for Tchen. Gisors notes that "this adolescent could not live with any ideology that did not immediately transform itself into acts." No group with a constructive purpose can provide activity continuous enough to meet such a requirement, particularly action of the intensity sought by Tchen. Constructive activity so rarely reaches this pitch that Tchen soon 


\section{ANDRE MALRAUX: TRAGIC HUMANIST}

reached the point where "only destruction made him whole." He who has this attitude will inescapably come into direct conflict with any social group, and Tchen is soon aware that "the world that they were making together condemned him, Tchen, just as much as did that of their enemies."

For Tchen, driven into this impasse by his obsessive desire for an absolute, there is no way into the world of men, and the progression moves to its logical conclusion: "Capable of conquering, but not of living in his victory, what could he look forward to except death?" Malraux wrote of Lawrence at the end of the Arabian campaign, "For the absolute, triumph is absurd." The entire course of Tchen's destiny evokes the "pale criminal," of whom Nietzsche wrote, "There is no salvation for him who thus suffereth from himself, unless it be speedy death. I tell you, however, that his soul wanted blood, not booty; he thirsted for the happiness of the knife." Ultimately, only death-inflicted on others and extreme with consequence even for the killer, or upon oneself, with the resultant terrible sharpening of intensity in the final moments of life-can answer such an extreme need for a personal absolute. Hong was executed by those on whose side he was fighting; Lawrence died racing his motorcycle along a dark country road; Tchen died in a suicidal assassination attempt that, significantly, served no end but his own. In all three cases the obsession with the absolute stood between these men and any real communion with their fellows. Malraux's conclusion seems clear: such an obsession has in it the potentiality for selfdestruction and, at the very least, leads to isolation and solitude. This obsession is often accompanied by the tendency to look upon those not sharing the absolute as inferior. Tchen, when told by Gisors that he must transmit his fatality if he is to live with it, replies, "Who would be worthy of it?"

When Malraux treats a specific religious absolute, it is usually Christianity; when he deals with a political one, it is most often communism. Background qualifies him to speak about the first, long experience about the 


\section{ANDRE MALRAUX: TRAGIC HUMANIST 213}

second. The younger Berger's reflection that in his life "he had encountered masses militant with political or religious faith" somehow summarizes Malraux's own involvement with both, and at the same time demonstrates his belief that in many of their manifestations they are the same. In the discussion of Malraux's ethics, we have noted some positive aspects in which the two are parallel; they also share a number of negative qualities. The history of many religions in regard to heretics, questioners, and simple non-believers needs no recounting here. Suffice it to say that any challenge to absolute rightness was dealt with summarily and harshly.

There emerges from Malraux's relationship with the Communist Party, both in real life and as reflected in his novels, a strikingly similar picture of a political absolute that is intolerant of any deviation. It is clear that Malraux, from the beginning, did not, as did the doctrinaire Communists, consider the Party and the revolution synonymous. On the personal level the revolution has always meant for him, as it did for Hernandez in Man's Hope, a means of accomplishing his ethical desires. On the larger human plane he saw, and still sees, it as the battle of the oppressed to obtain justice and a decent existence, rather than the inevitable progress of the dialectic. Hence, he has from the beginning been a heretic from the official point of view. The heresy is already implicit in Garine's remark about "the unbearable Bolshevick mentality with its stupid exaltation of discipline." It is explicit in Kyo's statement that he distrusts Marxism every time the sense of fatality in it gets the upper hand over the human will. It is no less explicit in Malraux's warning, issued in 1936, that "nothing would be more dangerous for revolutionary writers than to want to exchange their present and mortal heritage for one forecast by a long abstract theory." As far as orthodox Marxist thinking is concerned, this is almost tantamount to a Christian's denial of the doctrine of redemption through Christ.

If it is difficult to determine exactly when in Malraux's own life the absolute and the independent thinker became mutually intolerable, we 
may at least say that the fictional representation of this moment comes when the political commissar tells Magnin that "to act with the Party, is to act with it without reserves," which is the same thing as saying that the Party is an absolute.

Communist critics in particular have seized upon this difference between Magnin and the commissar to try to prove that Malraux can never really belong to any movement. Claude Roy, in his Descriptions critiques, writes of Malraux as having an "intellectual's incapacity for adhering without intimate reserves to any enterprise." Roger Garaudy simply accuses him of quitting the Loyalists because he couldn't take combat discipline, a somewhat absurd observation in view of Malraux's record in the tank corps and the Resistance. These criticisms deflect consideration of the problem from its true nature, which is simply: Was Malraux able to accept the Communist Party as an absolute? The answer clearly is that he was not. There remains the question of whether any political organization is worthy of such total faith and devotion. There is considerable irony in the case of Claude Roy, the communist critic cited above. An extremely intelligent and perceptive writer, he was expelled from the Party for a year, not long after he made the above comment on Malraux. The reason: he had differed with the Party on a matter of policy. An abject entreaty was necessary before he was officially reinstated.

Unlike many who lack his intimate experience with the Communists, Malraux does not accept the idea that their faith is only assumed, that it is a device of political expediency. They believe in their absolute as wholeheartedly as adherents of a religion. As he said in 1949, "Stalin believes in his truth, and his truth is without margins." And as Crane Brinton notes in his Anatomy of Revolution, the absolute is often practical politics also. It is, however, in ardent, total belief that the real danger lies, for in this is the source of isolation and intolerance. These two elements result as much from total faith in political absolutes as from total faith in the religious 


\section{ANDRE MALRAUX: TRAGIC HUMANIST 215}

variety. By its very nature an absolute requires not only fervent and complete faith but also the conviction that it contains the unquestioned truth about all mankind. "One cannot imagine," according to Malraux, "a civilization of the sacred that would consider its absolute hypothetical." Consequently, there derives from the absolute a positive and "marginless" definition of man. Not entirely illogically, then, the followers of an absolute are inclined to fully accept as men only those who fall within its own formula. A remark by Alvear in Man's Hope shows this process at work on both the political and the religious levels: "For me, being a man does not coincide with being a good Communist; to be a man, for a good Christian, meant to be a good Christian, and I distrust that."

Man has never been particularly hesitant about destroying anything not human, and it is but a step from the position of viewing others as not fully human to finding justification for exterminating them. The very existence of opinions outside the pattern prescribed by the absolute constitutes a denial or contradiction of it. Once again we are dealing with something that is no less true in the political than in the religious sphere. There is no essential difference between burning a man for heresy and shooting him for ideological deviation; both stem from the executioner's belief that he is the custodian of the absolute truth. To quote from Crane Brinton's chapter "The Religious Parallel": "If there is but one truth, and you have that truth completely, toleration of difference means an encouragement to error, crime, evil, sin." It was Malraux's reaction against this position that led him to have Le Negus say that the Communists had become curés who had neither honor nor fidelity toward anyone who was not one of theirs. This same criticism of communism's dogmatism and consequent self-willed isolation from the heritage of the West, rather than of communism per se, is the dominant note of almost everything Malraux has since had to say on the subject. Malraux's own political position I have described elsewhere as "political agnosticism," an exact parallel to his position in matters of 
religion. Frohock has accurately noted that, for Malraux, politics is a weapon against certain specific evils, not one for the application of an absolute social theory. As he has with the great religions, he has recognized and appreciated much that political theories have to offer and has even adopted some of their programs when they work toward what he sees as desirable aims. He accepts none of them as an absolute. It is significant that the Gaullism he has adopted is long on action for specific situations and short on abstract political theory. He has made it clear that he feels sociopolitical absolutes tend, as do religious ones, to isolate men, to put up barriers against human fraternity.

The Voices of Silence provides a clear delineation of Malraux's position on religion and what he feels to have been the results of its disappearance or decline as an absolute. In the Occident, this decline is, according to him, an extremely significant phenomenon. As is so often the case with the ideas in The Voices of Silence, the groundwork was laid in The Walnut Trees of Altenburg. Mollberg, functioning once again as the porte-parole for all the obstacles to human unity, gives a definition of the absolute and a conclusion as to what results from it that parallels comments in The Voices of Silence.

Whether it be a matter of God in religious civilizations or a link with the cosmos in earlier civilizations, each mental structure holds as absolute and unattackable a particular evidence that orders life and without which man could neither think nor act. It is this that seizes and possesses man entirely. Man never possesses it. So much is this so that men are, perhaps, most profoundly defined, and separated, by the form of their fatality.

The acceptance of such an absolute tends to turn the whole attention of the believers toward their absolute as the only real source of truth. Under such conditions it is highly unlikely that there would be any really important exchange of ideas with other groups of men. For Christian civiliza- 


\section{ANDRE MALRAUX: TRAGIC HUMANIST 217}

tion, the one with which Malraux deals primarily, this turning toward the absolute, toward God the Being, was complete for many centuries. Such a total concentration is, of course, possible only so long as there is no perspective on the absolute, so long as it colors, permeates, and dominates all thought and life. So long as it is, in Malraux's terms, "the aquarium in which all the fish swim"; for, as he has said elsewhere, "it is virtually impossible for a fish to judge the exterior form of his aquarium." This situation is what Malraux means by chrétienté, "the Christian world," as opposed to christianisme, the religion itself. It is the former that is the real absolute and that is disappearing. For this to take place, it is necessary for the fish to see the aquarium as a whole, and it is history that makes this possible.

The power of history, born with the weakening of the Christian world [chrétienté] and even of Christianity, is due neither to modern science nor to historical inquiries on the life of Christ or of Buddha, but to the fact that history encloses each religion in the prison of a circumscribed past. It strips it of its absolute, which the theosophies and the syncretisms evidently do not replace. And this absolute had prevented all profound communication.

A few pages later, he shows the results as they are manifested in the field of art:

When becoming or destiny is substituted for the Being, history is substituted for theology, and art appears in its plurality and in its metamorphosis. The absolutes metamorphosed by the arts then re-establish, with the pasts they model, the link between the Greek gods and the cosmos.

Thus, when the absolute quality of the religions has been stripped from them, it becomes possible to establish communication among the things they have produced, a link that is not possible while orientation toward the absolute is maintained. To use Malraux's own terminology, it is now 


\section{ANDRE MALRAUX: TRAGIC HUMANIST}

possible for dialogues to replace the long series of monologues. When this happens, he can write of "gods that have become fraternal," something they could never be while they were absolute.

What history and metamorphosis have really done with these absolute gods is to make them relative. However diverse they have been in their ultimate forms, they all represent, at least in part, the expression of a religious experience that is fundamentally the same everywhere. "It is the essential expression of the religious experience," he wrote in his Preface to Manès Sperber's Qu'une larme dans l'océan, "that seems today to be leading the agnostics to the relativity of the gods." Malraux has made his own agnosticism clear repeatedly. We are living in what he calls "the first agnostic civilization," a civilization whose rise Malraux had borne witness to when he had Ling declare, "for you the absolute reality was first God, then man. But after God, man too is dead."

These non-absolute, relativized gods cannot constitute for us the same affirmation of a sacred order that they represented for the people who originally worshipped them. By their very diversity and often contradictory natures, they lead to the agnostic civilization of which Malraux speaks, not to an affirmation, but to a question of the existence and nature of God or the gods and of man himself, which brings Malraux back to the essential quality of his humanism. In this passing of the absolute, man has both gained and lost. He has lost the confidence that comes with having a definite concept of what he is and where he is going, which one of his richest sources of inspiration. He has gained at least the possibility of a greatly increased tolerance and mutual understanding. In The Imaginary Museum the Greek god, the sculptured crucifix, and the Aztec idol can and do stand side by side without conflict and without incongruity. Without conflict, because for the first time they are in real communication with one another. Without incongruity, because they are all evidence of man's search for something beyond himself. They are also manifestations of the one 


\section{ANDRE MALRAUX: TRAGIC HUMANIST 219}

thing that, for Malraux, emerges more powerfully than any other from this waning of the absolute: human creativity. A large part of both the loss and the gain is implicit when he writes:

Although we know that a Khmer head of Buddha implies centuries of Buddhism, we look at it as though the sculptor had invented its spirit and its complexity. For us it has a "relativized absolute." Magic, cosmic, sacred, or religious, the great works from the depths of the past reach us like so many Zarathustras invented by so many Nietzsches. 



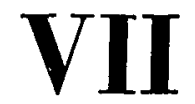

\section{THE INDIVIDUAL AND THE GULTURE}

The individual opposes the collectivity but he nourishes himself from it.

- "Days of Wrath" 

Wher dealing with the ethical aspects of Malraux's humanism, we indicated that his position was necessarily based on the dignity and value of the individual. The "heroic sense," on the other hand, requires the individual to link his destiny to that of a group. Prometheus would have been much less attractive had his struggle with Zeus been purely personal. Malraux has also made it clear that, although the fullest happiness derives from service to humanity, the political and social forms established by various segments of humanity exist primarily to serve their individual members. He has, therefore, been faced with the problem of trying to work out a relationship between the individual and the group that satisfies these somewhat contradictory requirements. His deep interest in creativity has intensified his preoccupation with the matter because the relationship of the creative individual to the society presents the question in one of its most acute forms. One has only to read his series of addresses to leftist cultural congresses during the mid-1930's to realize that although a dedicated leftist himself at the time, he was intensely aware of the potential danger in trying to force the artist to conform too closely to a group pattern. He was also aware that to treat the individual as an absolute was to invite chaos, anarchy, and isolation. The problem becomes one of finding a relationship by which both the individual and the group would be mutually enriched. The creative person almost by definition cannot fully accept his group as he finds it, but neither does Malraux believe in creation in vacuo. The artist draws upon the heritage of the group, and Malraux has 
sought a position between extreme individualism and total conformity to the group. He is after a median attitude in which the individual does not exist solely for the group but realizes nevertheless that he has a significant relationship to it. This is a central problem in any real humanism, and it is all the more urgent for Malraux because he feels that "man is now being devoured by the masses as he formerly was by the individual."

He has long been aware of an impasse in the pursuit of individualism for its own sake. The Temptation of the West suggests a distinct possibility that one of the major reasons for Malraux's deep interest in the Orient was that he was seeking a way out of this dead end to which he felt the Occident had already come. A.D. writes to his Chinese correspondent Ling that "the Europeans are tired of themselves, tired of their crumbling individualism." He has reached the conclusion that the absurd "is the extreme point of the particular." We can accept this as Malraux's own position because he returns to it in his essay D'une jeunesse européenne, developing it so as to state that "to push the search for oneself to the extreme while accepting one's own world is to tend to the absurd." The introduction of the absurd would indicate that Malraux believes that extreme individualism parallels the action of destiny in reducing man to absurdity and isolation. This same essay, while reflecting an extreme dissatisfaction with the superindividualistic orientation of occidental society, nevertheless does not fall into the trap of using discontent with society as an excuse for rejecting it or feeling superior to it, as the extreme individualist frequently does. Malraux writes of contemporary European youth as being "delivered from the base vanity of calling grandeur the disdain for a life to which it does not know how to link itself." Implied is the whole vicious circle in which a man is caught when he is schooled in extreme individualism by a society that has had this individualism as its dominant value but then has lost faith in it.

Man's Fate, which introduces the "heroic sense," also furnishes the harsh- 


\section{ANDRE MALRAUX: TRAGIC HUMANIST 225}

est of all Malraux's condemnations of excessive individualism. Ferral, a determined individualist, muses that perhaps "great individualism could develop fully only on a manure heap of hypocrisy." In Days of Wrath Malraux calls it the enemy of virile fraternity and accuses it of being born "less from the desire to create the complete man than from the fanatical desire to be different."

Many of Malraux's political critics are inclined to pass off the preceding remarks as due to the disciplining effect of communism on his thought and to say that with the passing of that discipline he returned to his "natural" hyperindividualistic position. Such criticism is invalid on at least two points. None of Malraux's writing prior to his association with the Communists reveals any such position, nor do his later works show any "return" to it. The Walnut Trees of Altenburg finds Vincent Berger warning that "you do not find man by scratching away ceaselessly at the individual." The Voices of Silence declares, "The individual dependent entirely upon himself perceives that he does not count for very much."

The fact is that Malraux's early contact with the Orient put him in touch with a world that emphasizes the exact opposite of the cult of the individual. "The supreme beauty of a refined civilization," wrote Ling, "is an attentive non-cultivation of the ego." This is a position the present-day Malraux might find too extreme, but at the time he thought enough of the remark to use it again as the epigraph for D'une jeunesse européenne, thus lending support to the hypothesis that one of the things Malraux was seeking in the Orient was an antidote for the excessive individualism he felt to be prevalent in Europe. When the discussion in The Temptation of the West comes to an actual comparison of Eastern and Western societies, an idea emerges that will preoccupy Malraux for many years: Christianity is the major source of European individualism. Early in the book, Ling notes that "Christianity seems to me the school in which are formed all the sensations thanks to which the individual forms a consciousness of him- 
self." The belief that Christianity leads the individual to think of himself as an entity distinct from all other men will lead Malraux to write later, in Etude sur Laclos, "However profound the Christian experience of the world may be, it always culminates in a solitude." Against this, Ling sets the morality of Confucianism which, according to him, is completely social -so much so that the individual has no awareness of himself at all, except as part of the world as a whole. Malraux has apparently found the antipodes of the society he had left. He now has had experience with the two extremes between which he had to seek, and to a large degree is still seeking, a balance.

His works provide some interesting examples of what, in his opinion, can happen when a poverty-stricken Oriental, coming from a culture unaware of the individual as such, is brought into contact with Christianity and its concomitant emphasis on each man as an individual. So long as he remains wholly a part of his own society, his lack of awareness of his value as an individual keeps him from rebelling against his suffering. Christianity, by teaching him that he is a distinct person, lets him know that he is suffering at the hands of other persons but offers him the possibility of an afterlife in which his misery will be compensated. If the inoculation of Christianity does not take, he is left with the consciousness that he is suffering unjustly but without the promise of an afterlife. Then, says Ling, "the individual is born in them and with it that strange taste for anarchy and destruction."

In this The Conquerors represents an application of ideas discussed in the earlier work to persons and situations. Garine, in attempting to explain Hong's fanatical hatred to the narrator of the novel, picks up the above idea and carries it on:

Wasn't it just such a feeling: that of having an individual life, distinct in the eyes of God, that was the strength of Christianity. I see evidence every day that there is no great distance between such feelings and hatred, even the fanaticism of hatred. 


\section{ANDRE MALRAUX: TRAGIC HUMANIST 227}

At another point he recapitulates the entire process and explains much of what was happening in Asia in terms of it:

All modern Asia is in the midst of the feeling of individual life, of the discovery of death. The poor have understood that their suffering is hopeless, that they can expect nothing from a new life. The lepers, who have ceased believing, are poisoning the fountains. Every man who is detached from Chinese life with its rites and vague beliefs and who is rebellious to Christianity is a good revolutionary. You will see marvelous examples of this in Hong and all the terrorists that you happen to meet.

Malraux's oriental experience provided him with no satisfactory answer to the riddle of a mutually fertile relationship between the individual and the group. He was becoming increasingly involved with communism, and for a while it may have seemed to him that it might provide the solution. "In the eyes of Kassner as in those of a number of communist intellectuals," he wrote in the Preface to Days of Wrath, "communism gives back to the individual his fertility." Much the same note is struck in Malraux's speeches during this period, but there is also distrust of the Party's increasing dogmatism and demand for absolute conformity. With the passage of time, it became evident that this tentative answer, too, had failed to meet the test of being a balance between the two extremes.

The same preface attempts to come to grips with the heart of the problem which it states as, "The individual opposes the collectivity, but he nourishes himself on it." The categorical nature of this statement dismisses once and for all, as far as Malraux is concerned, the idea of the individual who can fully exist without drawing upon society. He reinforces this point with the assertion that "all psychological life is an exchange, and the fundamental problem of the concrete person is to know upon what he intends to nourish himself." In terms of this statement, the individual must draw upon some culture but has the choice of its aspects and quite possibly that of se- 
lection among available cultures. Equally important is the idea of exchange with its implication that the culture is nourished by the individual as well as vice versa, thus bestowing an irreducible value on each person. Even more significant in Malraux's search for a productive relationship is the fact that, after having recognized that the individual both opposes the collectivity and draws upon it, he chooses to assign an order value to these two phenomena. "The important thing," he goes on to say, "is much less to know what he opposes than on what he intends to nourish himself. Like the genius, the individual has value by virtue of what he contains." Malraux's entire ethics attests his belief that each individual has an inherent value apart from society. These words constitute recognition by Malraux, then struggling against many aspects of his own society, that, even if one opposes his own collectivity, he is largely made up of his heritage from it. It is, therefore, the fundamental recognition necessary for a fertile link between the two.

Malraux does not depart from this recognition. The Voices of Silence finds him making such affirmations as, "No grandeur is separable from that which maintains it"; "Genius is inseparable from that of which it is born"; and, "Art survives more because of that on which it is nourished than because of what it preaches." All this in no way implies that the individual is to be swallowed up by the group but simply that he must be conscious of its contribution to him. The exchange is necessarily two-way, and the individual, even while opposing the group (and, actually, by doing so) can enrich it. Treating this matter as it relates to art, he asserts, "As a creator, the artist does not belong to the collectivity that submits to a culture but to the one that elaborates it." Here then is the fertile relationship toward which Malraux had been working. In it the individual recognizes his debt to the cultural heritage without subjecting his creative powers to a total acceptance of it. In the exercise of these powers, he in turn enriches the culture that gave rise to him. 


\section{ANDRE MALRAUX: TRAGIC HUMANIST 229}

In dealing with the individual Malraux finds a phenomenon somewhat parallel to the one that strips the religions of their absolute quality. "The same conquest of the world," he notes in The Voices of Silence, "that made modern individualism very different from that of the Renaissance is today relativizing the individual." Apparently, this process involves no real impingement on the individual himself; for Malraux goes on to say that in it "the individual in no way renounces his own conquest, but ceases to find in it his raison d'être." The implication is that the individual abrogates none of his creative potentialities but that he exercises them, not so much for their own sake, as for the benefit of the group.

Although Malraux here attributes the emergence of the "relativized individual" to the processes of modern history, one is inclined to wonder if something far older is not involved. He has, as has been indicated, said that in many ways our world is more nearly like that of the ancient Greeks than any other. The individual-group relationship visualized in the foregoing lines resembles that of the Greek polis even more than it does contemporary occidental society, of which they, perhaps, describe the potentiality rather than the actuality.

Potentiality, or possibility, is a key word, for, as does everything in Malraux's humanism, culture depends on conscience. He has at one point defined the former as everything that man does "in order to transform destiny into conscience." With consciousness of the nature and possibilities of this type of relationship, Malraux feels, an ever widening circle of accomplishment is opened up for both the society and the individual. Far from being diminished by recognition of the fact that he owes much to his heritage, the individual will be augmented thereby. "The quality of the world may be the raw material of all culture, but the quality of man is its goal." Ours, says Malraux, is the first generation that has the entire world as its cultural heritage. What this tells us is the same thing that Malraux's entire tragic humanism tells us: contemporary man, even though he does not know 


\section{ANDRE MALRAUX: TRAGIC HUMANIST}

where he is going, even though he might have no illusions about his destiny, even though he is menaced from without and within as never before, has the possibility for living the fullest, richest, and most intense life of any man in history if he so chooses.

Of this there is no better example than André Malraux's own life. 


\section{EPILOGUE ON THE TRAGEDY OF POLITIGAL ACTION}



As of THIS WRITING, four years have passed since Malraux abandoned writing to return to politics, four years that have seen the Franco-Algerian conflict, which brought De Gaulle back to power, concluded, officially at least, by a cease-fire. The time lapse is, I believe, sufficient to justify an examination of Malraux's political role in the light of the philosophy that has been discussed.

Two factors stand out immediately as one views his latest venture into the political arena. The situation, as it always is when Malraux becomes involved, is one of crisis, requiring extreme measures. Secondly, the sequence of posts he has held, Minister of Information, Minister Delegate, and Minister of Cultural Affairs, shows a progressive withdrawal from specifically political action. In fact, the only time in the last three years that he has done anything directly related to France's bitter struggle resulted from the same kind of clear-cut situation that led to his combat in the French Army and subsequently in the Resistance during World War II: there was an overt threat of armed aggression. During the second night of the generals' putsch in April, 1961, it was believed that mutinous paratroopers might make an attack on Paris. Malraux went to the Ministry of the Interior to exhort and help organize the civilian volunteers who were being armed to face the menace. With the passing of the immediate crisis he withdrew from all public connection with the affair.

While the larger withdrawal is natural in the light of Malraux's stated preference for cultural activity, it also suggests another possibility: the 


\section{ANDRE MALRAUX: TRAGIC HUMANIST}

exigencies of strong political action, however desirable its goal might be, require the modification or abandonment of his basic ethical beliefs. In short, he found himself once more in a situation similar to that reflected in the ethical debates of Man's Hope. Seen from this angle, his movement through the various governmental posts can also be interpreted as an effort to maintain his own personal standards while remaining loyal to De Gaulle and what he stands for. Of his sincere belief in the general and his aims, there is no real doubt. Malraux's personal struggle is once again an effort "to win without self-betrayal," to minimize the tragedy of political action.

But how successful has he been? To what degree is it possible to avoid this inherent tragedy? Two incidents, which occurred in 1961, can serve to give us some insight into the dilemma in which Malraux finds himself. Both of them involved highly questionable actions by a ministry of the government, in neither case Malraux's own. The first example is furnished by two answers to an inquiry conducted by the newspaper Arts et Spectacles on the occasion of Malraux's sixtieth birthday. A number of prominent French writers were polled in order to try to evaluate Malraux's influence, past and present. The usual suspicion of a writer, and particularly a revolutionary one who has become a government minister, was expressed; but a specific objection, made by both Robert Abirached and Guy Dumur, is much more indicative of the nature of Malraux's problem. They found it very damaging that a republican combatant of the Spanish Civil War, the author of Man's Hope, should be a member of a government that had arrested El Campesino, a fighter on the same side, in exchange for the confinement of some OAS leaders in Spain. While this complaint has its pertinence, the inquiry involved Malraux only as a subject and did not solicit any response from him.

A far more serious and direct problem was posed by the open letter to Malraux from Jérôme Lindon, director of Les Editions de Minuit, a publishing house that was established to print French resistance literature dur- 


\section{ANDRE MALRAUX: TRAGIC HUMANIST 235}

ing World War II. Les Editions de Minuit is also distinguished by the fact that it has had more books on the Algerian conflict seized by government order than any other press. Lindon wrote to Malraux, although Malraux's ministry was not the one involved, to protest the confiscation of Pierre Leuillette's Saint Michel et le dragon, assuming that the action had been taken because the book included a scene in which French parachutists tortured a Moslem. The first letter was private; but when it went unanswered, Lindon informed Malraux by registered mail that if he had received no response after a few days, he would make the contents public. There was no reply and the letter appeared in the January 18, 1962, issue of L'Express. To the best of my knowledge, Malraux has made no public reference to the matter, although the situation described by Lindon clearly requires rectification, and, significantly, requires it in terms of Malraux's own personal philosophy. Torture is too flagrant a violation of his ethics, state control and seizure of books too much in contradiction with the freedom of art and culture, for Malraux not to have been aware of the critical implications of this letter. Lindon himself pointed out that in a parallel case, the confiscation of Henri Alleg's La Question, Malraux, who then occupied a different ministerial position, had come to his aid, to demand that both the seizure and the torture with which the book dealt be investigated.

However, an examination of the consequences and complications that would result from the possible courses of action open to Malraux reveals the extent of his dilemma and the depth of conflict between ethics and political action that he faces. To have answered the Lindon letter, either publicly or privately, with condemnation of the action would have meant that one minister of the government was attacking another at a time when the whole government was dangerously threatened. To have offered a defense of the action would have been unthinkable in terms of Malraux's own convictions. Should he have resigned from a government in which such things happen? That the De Gaulle cabinet is split into opposing factions, 
some of which do not always act in ways that coincide with the general's views, is common knowledge. It is also generally accepted that Malraux is one of the more liberal members of the presidential entourage as well as De Gaulle's closest confidant. To have deserted De Gaulle at this critical point would not only have been an act of moral cowardice, a betrayal of the loyalty on which he puts such a high value, but would have isolated De Gaulle still more, and at the same time marked an advance for the very elements that perpetrated the seizure. Clearly, it is unsatisfactory, to put it mildly, to let such a letter go unanswered, but the situation is one in which every path leads to some form of abdication. The choice made was apparently for the least of the unavoidable evils.

Yet another incident, in which Malraux himself was the intended victim, served to sharpen the tragic overtones in his current activity, an incident which may well have recalled to him the Dostoevski story concerning the suffering of an innocent child to which he referred in The Voices of Silence. The OAS, in an attempt to bomb him, blinded for life a four-year-old girl living in the apartment below his. To do anything that might weaken the De Gaulle regime when it was menaced by enemies capable of this kind of action would be in itself a form of treason, even if he is fully aware that elements in it are acting in a fashion directly contradictory to his most basic beliefs.

It would appear, therefore, that although Malraux may have succeded in avoiding active participation in anything violating the precepts of his own humanism, the tragic conflict, which he early saw as inherent in all political action, remains tragic and has made him pay a high price in personal anguish for his most recent involvement. 


\section{APPENDIX}

Address Given by His Excellency André Malraux, Minister for Cultural Affairs of the French Republic, on the Occasion of the Fiftieth Anniversary of the French Institute of New York, on Tuesday, May 15, 1962 

Among so many friends of France, I recognize a number of long-familiar faces; some of you I have known since the end of World War I. And perhaps all of you whom I have the honor of addressing this evening will understand better what I have to say if I try to speak to you across these affectionate and steadfast faces. In the worst days, you stood by us. When France seemed to be her own widow, consumed with her burning cities When you believed you were witnessing Europe's final agony. And more than once you have stood by the man who, during my country's terrible sleep, sustained her honor like an invincible dream.

To have done so is to your considerable credit. As it is to do so today. For since the birth of the Fifth Republic, you have been told-we have been told-that it is in its death throes. We have also been told that the French people would reject the Constitution, that the State could neither stabilize the franc nor restore the economy, that the President of the Republic was a pawn of the extreme right, that the Government would never dare arrest a single rebel general. You know what was said. These four years, the "fascism" of the Fifth Republic has been berated with indignation and impunity by men who have already forgotten that the fascists in their own countries were not suffering insult; these four years, we have been told that France is not about to become France again.

The agreements signed at Evian prove the contrary.

But these agreements are a stage, not a goal.

What was the situation in 1958 ?

Every interest that favored the subjection of the State, a powerful Communist Party, and the Algerian drama as well, combined their forces. In Madagascar, the wounds of 1950 were still open. Within one year, at the sole cost of Guinea's secession, twelve African states acceded to independence. Under a form unlikely to re- 


\section{ANDRE MALRAUX: TRAGIC HUMANIST}

main that of the French Community? No matter. We had seen its flags, on which a white hand and a black, clasped, surmounted the staff; and when, during the Liberation celebrations in Brazzaville, I raised in my own the African hand of the President of the Congo, a fraternal shout acknowledged the living flag of that Community. From the Congo to Senegal, the voice of France has awakened the oldest voice of Africa, the throbbing of the war drums which are also the drums of dancing. In Chad, dark heart of the continent where a few hundred fishermen once gathered, association with France was hailed by the exaltation of forty thousand dancers I have had the honor of meeting you in Dakar, Mr. Vice President, do us this justice, that in the realm of decolonization, we could have answered each of the attacks against us in the name of the greatest celebration age-old Africa has ever known

But it is not such attacks, nor is it the hostile voices raised against us, it is the oldest beating of her heart which for three years has forbidden France to efface, even by a vast procession of joy, the name you all know: Algeria.

It has not been sufficiently understood that Algeria represents a unique problem: her situation has been mistakenly likened to that of the Asian colonies. But in India, there were 30,000 Englishmen and more than 300 million Indians: a proportion of one to ten thousand. In Algeria there are one million Frenchmen, at least a million Algerians intimately linked to France for over half a century, and seven million Arabs: a proportion of almost one to four. Can we imagine 80 million Englishmen living in an India where terrorism would have replaced nonviolence?

France has chosen self-determination because she has chosen justice, but justice does not mean abandoning innocence, nor betraying allegiance. The Evian agreements were difficult to achieve, and your press rightly defined them as the most poignant heroic act of a long-term undertaking. Their application will also be difficult, and will require all our energy, as well as that of our adversaries of yesterday. But we must realize that if the end of the Algerian war is a historic date, it is chiefly because this war jeopardized the world's nearly two-hundred-year-old image of France, France's image of herself. Frenchmen listening to me tonight, let me tell you, almost in a whisper, what you all know. Along many roads in the East are the graves of French Crusaders: along many roads in Europe are the graves of soldiers of the Revolution. Some nations, like England, are never greater than when 


\section{ANDRE MALRAUX: TRAGIC HUMANIST 241}

they entrench themselves at home; others, like France and the United States, are perhaps most themselves in the world's eyes when they fight for the world. Here tonight is one of my American friends who fought at Verdun, another who hung out her flag for the liberation of Paris. Both know that many graves in Algeria are sisters of the graves at Verdun and Paris. But at Evian they have rediscovered the France they loved.

It is because the French people have rediscovered the soul of our country that the Evian agreements are a stage and not a goal. The Constitution, economic recovery, decolonization, peace in Algeria are merely the successive or simultaneous means of France's resurrection. General de Gaulle did not come to bring the Algerian drama to an end so that France may peacefully return to the old cascades of ministries, inflation and national renunciation; France has not called General de Gaulle to power so that he may comfortably insure her agony, but because she wanted to become France once more. May 13 was also a symptom. Destiny will sweep away the Algerian drama, as the rivers of Africa sweep away their uprooted islands, after years of effort. In the breathtaking transformation of the world taking place before our eyes, as our nation, which was demographically one of the oldest in Europe, is in the process of becoming one of the youngest, Gaullim is primarily the effort to bring to fruition what France bears within herself.

Slowly, patiently, firmly.

With this in mind, Ladies and Gentlemen, several of you have asked me to speak tonight about the culture which it is my function to serve in France. Some are members of the academic world: nothing could be more natural. Others belong to the world of politics: nothing could be more novel.

A gathering such as this would have been inconceivable fifty ycars ago. In the last year, attendance figures for exhibitions of painting were higher than those for stadiums; the cities of art have become the cities of pilgrimage; one after the other, governments-in the Soviet Union as in the United States-are creating or developing Ministries of Cultural Affairs. But the idea of culture becomes the more obsessive, the less concerned we are to define it.

The word civilized is opposed to the word barbarous; the word cultured, first of all, to the word ignorant. And yet the scholar, the man of knowledge, has often secmed a caricature of the cultured man. Doubtless the latter is a man of books, of 


\section{ANDRE MALRAUX: TRAGIC HUMANIST}

works of art-a man with a relation to the specific testimony of the past. But it would be futile for him to know such testimony if he did not first love it. True culture begins when works are no longer documents: When Shakespeare is present. What kind of presence do I mean? The presence of Michelangelo and Piero della Francesca, of Velasquez and El Greco, of Cézanne and the sculptors of Chartres, of the Egyptian and Sumerian masters, of Monteverdi and Beethoven; of our record collection, our library and our museum without walls. Knowledge is the study of Rembrandt, Shakespeare or Monteverdi; culture is our emotion on seeing The Night Watch, a performance of Macbeth, a production of Orfeo. Our Culture is the mysterious presence, in each of our lives, of what should belong to death.

And it would be incomprehensible that this presence should disturb intellectuals, artists and governments if they did not discover it in an age when an upheaval of the imagination has occurred in every part of the world touched by modern industry: radio, records and especially the popular press, films and television-what we call the mass media are pouring forth the enormous flood of dreams that we now call mass culture.

Which our intellectual culture seems to oppose.

It is true that the mental level of the films based on War and Peace and Anna Karenina is incomparably inferior to that of Tolstoy's novels; it is true that the mental level of the cinema, and particularly its emotional level, is quite low. But without the film, the millions who have seen Anna Karenina would never have read the novel; and Westerns have succeeded neither Plato nor Balzac, they have succeeded The Three Musketeers and Treasure Island. Films that tell a stupid love story in magnificent images have replaced novels which tell a love story quite stupid in execrable prose. Our cinematic output does not belong to culture in the old sense of the word, but our art films, the selections of our film societies, certainly do. Every quality of a work contributes to the quality of man.

Let us remember that this industrialization of dreams has nothing in common with what the influence of a novel or a play used to be. A century ago, the combined public for all the popular entertainments in Paris totaled less than three thousand persons an evening. And today's public is not a popular public, strictly speaking: mass art is not class art. This new collectivity has produced the new expression of its feelings, and, more important, of its fantasies-an expression served by 


\section{ANDRE MALRAUX: TRAGIC HUMANIST 243}

unprecedented means of circulation. Our civilization produces as many dreams in a week as it does machines in a year, thereby instituting a fantasy-life which the world has never known, and whose presence in the real lives of hundreds of millions of human beings is quite different from the fictional or legendary presences of the past: it can only be compared to what was once the obsessive presence of the religious imagination.

And if States, one after the other, create Ministries of Cultural Affairs, it is because every civilization is threatened by the proliferation of its fantasy-life, if this fantasy-life is not oriented by values.

For thousands of years, these values have been religious values. The Renaissance substituted a culture of the mind for a culture of the soul, invoking the standards of Greece, first creator of a culture of the mind in opposition to the Eastern cultures, which were all cultures of the soul; but the imaginative forms, the fantasylife of the Renaissance was not a mass dream, and our peasants did not offer sacrifices to Pan, except in Ronsard's poems. The American Revolution, the French Revolution fostered great, stirring dreams-confined to history. To rediscover an imaginative form which includes the real and the unreal, emotions and the phantasmagorical, we must look back to our Middle Ages. And indeed our Middle Ages had their noble Courts of Love; but the fate of Christianity was not decided in the Courts of Love, it was determined by those who, looking quite objectively at the tenth-century mercenaries they saw around them, resolved to bring knighthood into flower from them.

In the most tumultuous tidal wave of dreams humanity has ever experienced, we vaguely realize that we too must find our knighthood, our chivalry. But what values can orient these dreams, which seem to ignore all values?

A masterpiece-Macbeth or Don Quixote, a novel by Balzac, Stendhal or Tolstoy, is made into a film. This film, in turn, is rewritten as a serial, a comic book, even as a "retold" novel. One section of the film public reads the popularization, another reads the original work. For the latter audience, even if they are making their first contact with genius, what will be the difference between the film and the masterpiece? They will find in it the reflection of poetry instead of poetic creation, the reflection of human experience instead of the human experience, a simplified and no doubt "actualized" account. The closer the film comes to the work the better it 


\section{ANDRE MALRAUX: TRAGIC HUMANIST}

will be, not because it transmits its images more faithfully, but because it transmits more effectively what makes the work a masterpiece. Of course the cinema was not created to illustrate literature. But it allows us to discover that what separates a film from the poetry or from the human experience of Macbeth or Don Quixote, from The Charterhouse of Parma or War and Peace, is what separates the wonLD OF REFERENCE in the masterpiece from the world of reference in the film. And that world, in each masterpiece, is primarily the domain of the masterpieces that have preceded it: the invincible permanence of what has triumphed over death-which we call culture.

We must realize that it is not a question of models. Stendhal, writing The Charterhouse of Parma, wrote for the future, in the name of the past: he wrote for us, in the name of Molière, of Correggio and of Mozart. Which means that he tried to compete with these men in the quality of the action they exert upon us. For a great artist's masters are not models, they are rivals.

Culture is the highest form of rivalry humanity knows. It does not act upon the fantasy-life, like religious values, by its exemplary nature; it orients that life, and orients it "up," by obliging it to compete with the greatest human dreams.

Of course, it is the past. But not, as it once was, a privileged past, a model past. From now on, culture must include all the past. To the wave of fantasy breaking over every city erected by our industrial civilization corresponds the discovery and appreciation of the past of the entire earth. Never have painters admired so many forms of so many civilizations; but what they have found in so many museums is not more forms of servitude, it is the profoundest freedom.

The treasure of the ages, the living past-which has nothing to do with collections-does not consist of works which happen to have survived by accident, but of works which bear in themselves, like a phosphorescence, that power of survival by which they speak to us. The masses do not choose their fantasies, and we choose our museums much less than we suppose. But confronting the great shapeless dream surging out of the unconscious of crowds, with its imperious demons, its childish angels and cheap heroes, stand the only forces as powerful as they, and which we acknowledge only by their victory over death.

Assuredly the age in which Chaplin and Garbo have taught us that a single artist can make the universe laugh or cry is also the age of the least accessible arts hu- 


\section{ANDRE MALRAUX: TRAGIC HUMANIST 245}

manity has ever produced. But this startling opposition is negligible in the resurrection of the past. Our civilization has kept Michelangelo and revived the Romanesque churches, the archaic Greeks and the temple sculptures of the East, of China and India: the great powers of the Soul. Confronted with a nascent art of the masses, our age has resuscitated the art of crowds.

Twenty years ago, a Swiss newspaper asked me what I thought the chief intellectual consequences of the war would be; I answered: "The birth of an Atlantic civilization." The dialogue between a fantasy-life sweeping over half the world and the resurrection of a global past is not a minor characteristic of this eivilization. But in such a dialogue, it is well to note one characteristic, too little remarked on, of the United States.

In the course of history, all empires have been created with premeditation, by an effort often sustained over several generations. Every power has been Roman, to a degree. The United States is the first nation to become the most powerful in the world without having sought to be so. Its exceptional energy and organization have never been oriented toward conquest.

The contrary obtains in the Communist States, whose hegemony, should it come to pass, would seem the consequence of an obstinate and deliberate combat. For Marxist thought, history is the history of a progress and of a social liberation, and the future must complete that liberation. Meanwhile, its propaganda attempts to create imaginative forms that rectify the world according to its own law, and substitutes for the vague aspiration of the masses the rigorous pulpiteering of the Party.

But the intellectual, the artistic history of the West is not that of capitalismwhich often constrained those who made that history to a life of poverty. If Van Gogh belonged to the capitalism whose painting he opposed, Lenin would belong to Tsarism. The United States does not oppose the Marxist concept of culture and fantasy-life with another concept of combat. Like the West, the United States opposes the Marxist concert with freedom of interpretation in regard to the past; with freedom of creation in regard to the present. And also with a singular discovery, which is art's power of metamorphosis. "However terrible an age, its art transmits only its music. Living humanity inexorably transmits its monsters with its blood; but the humanity of dead artists, when it transmits a scourge like the Assyrian hor- 


\section{ANDRE MALRAUX: TRAGIC HUMANIST}

ror, for all the torturer-kings of its reliefs, fills our memory with the majesty of the "Wounded Lioness." And one of the emotions this creature inspires in us is pity. If an art were to be born from the crematory ovens of our age, it would not express the executioners, it would express the martyrs."

It is still essential that freedom not be defeated, and our magnets of fiction are all too tempted by the most dangerous demons of the West. In the battle for the human imagination, a civilization unwilling to impose their dreams on all its members must give each his opportunity. In other words, put the greatest number of great works in the service of the greatest number of men. Culture is the free world's most powerful guardian against the demons of its dreams; its most powerful ally in leading humanity to a dream worthy of man-because it is the heritage of the world's noblesse.

For culture, for an Atlantic civilization, for the freedom of the mind, I offer a toast to the only nation that has waged war but not worshipped it, that has won the greatest power in the world but not sought it, that has wrought the greatest weapon of death but not wished to wield it;

and may it inspire men with dreams worthy of its action. 


\section{BIBLIOGRAPHY}

A. Books by Malraux

Lunes en papier. Paris: Simon, 1921.

La Tentation de l'Occident. Paris: Grasset, 1926.

Les Conquérants. Paris: Grasset, 1928.

Royaume farfelu. Paris: Gallimard, 1928.

La Voie Royale. Paris: Grasset, 1930.

Euvres Gothico-Bouddhiques du Pamir. Paris: Gallimard, 1930.

La Condition Humaine. Paris: Gallimard, 1933.

Le Temps du Mépris. Paris: Gallimard, 1935.

L'Espoir. Paris: Gallimard, 1937.

Tableau de la littérature française. Paris: Gallimard, 1939.

La Lutte avec l'Ange. Lausanne-Yverdon: Editions du haut pays, 1943.

Euvres complètes. Geneva: Skira, 1945.

Scènes choisies. Paris: Gallimard, 1946.

Esquisse d'une psychologie du cinéma. Paris: Gallimard, 1946.

Goya: Dessins du Musée du Prado. Geneva: Skira, 1947. 


\section{ANDRE MALRAUX: TRAGIC HUMANIST}

Le Musée Imaginaire. (La Psychologie de l'art, Vol. I.) Geneva: Skira, 1947. Romans. Paris: Pléiade edition, 1947.

La Création artistique. (La Psychologie de l'art, Vol. II.) Geneva: Skira, 1949.

Les Conquérants. "Version définitive" with Postface. Paris: Grasset, 1949.

The Case for De Gaulle, with James Burnham. A "dialogue." New York: Random House, 1949.

La Monnaie de l'absolu. (La Psychologie de l'art, Vol. III.) Paris: Skira, 1950.

Saturne. Paris: Gallimard, 1950.

Les Voix du silence. Paris: Gallimard, 1951.

Le Musée imaginaire de la sculpture mondiale, Vol. I. Paris: Gallimard, 1952.

Le Musée imaginaire de la sculpture mondiale: Des Bas-reliefs aux grottes sacrées. Paris: Gallimard, 1954.

Le Musée imaginaire de la sculpture mondiale: Le Monde chrétien. Paris: Gallimard, 1954.

Du Musée. Paris: Editions Estienne, 1955.

La Métamorphose des Dieux. Paris: Gallimard, 1957.

English Language Editions of Works by Malraux Cited in This Book

The Conquerors. Translated by Winifred Stephens Whale. New York: Random House, 1929.

Man's Fate. Translated by HaAkon Chevalier. New York: Modern Library, 1934.

The Royal Way. Translated by Stuart Gilbert. New York: Random House, 1935.

Days of Wrath. Translated by Haakon Chevalier. New York: Random House, 1936. 


\section{ANDRE MALRAUX: TRAGIC HUMANIST 249}

Man's Hope. Translated by Stuart Gilbert and Alistair MacDonald. New York: Random House, 1938.

The Walnut Trees of Altenburg. Translated by A. W. FieLding. London: John Lehmann Ltd., 1952.

The Voices of Silence. Translated by Stuart Gilbert. Garden City, N. Y.: Doubleday and Co., 1953.

Saturn: An Essay on Goya. Translated by C. W. Chilton. London: Phaidon Publishers, 1957.

The Metamorphosis of the Gods. Translated by Stuart Gilbert. Garden City, N. Y.: Doubleday and Co., 1960.

The Temptation of the West. Translated and with an Introduction by RoBerT HoLLANDER. New York: Vintage Books, 1961.

\section{B. Articles, Prefaces, and Reviews by Malraux}

"Des Origines de la poesie cubiste," La Connaissance, Vol. I, No. 1 (January, 1920), $38-43$.

“Trois Livres de Tailhaoe," La Connaisance, Vol. I, No. 2 (February, 1920), 196-97. "La Genèse des chants de Maldoror," Action, No. 3 (April, 1920), pp. 13-14.

"Mobilités," Action, No. 4 (July, 1920), pp. 13-14.

"Prologue," Action, No. 5 (October, 1920), pp. 18-20.

"Journal d'un pompier du jeu de massacre," Action, No. 8 (August, 1921), pp. $16-18$.

"Aspects d'André Gide," Action, $3^{\text {e }}$ année [not numbered] (March-April, 1922), pp. $17-21$. 


\section{ANDRE MALRAUX: TRAGIC HUMANIST}

Review of L'Abbaye de Typhaines, by Le Comte de Gobineau, Nouvelle Revue Française, July, 1922, pp. 97-98.

Review of Art Poétique, by Max JAcoB, Nouvelle Revue Française, August, 1922, pp. 227-28.

Review of Malice, by Pierre Mac Ordan, Nouvelle Revue Française, May, 1923, pp. 836-37.

Introduction to Mademoiselle Monk, by Charles Maurras. Paris: Stock, 1923.

"D'une jeunesse européenne," Ecrits. (Les Cahiers Verts, Vol. LXX.) Paris: Grasset, 1927.

"Le Voyage aux îles fortunées," Commerce, Cahier 12 (Summer, 1927), pp. 95-131.

Review of Histoire de la Bienheureuse Raton, Fille de Joie, by Fernand Fleuret, Nouvelle Revue Française, March, 1927, pp. 550-51.

Review of Défense de l'Occident, by Henrr Massrs, Nouvelle Revue Française, June, 1927, pp. 813-18.

Review of Bouddha Vivant, by Paul Morand, Nouvelle Reveue Française, August, 1927 , pp. 253-55.

Review of Histoire Comique de Francion, by Charles Sorel, Nouvelle Revue Française, November, 1927, pp. 686-88.

Review of Où le coeur se partage, by Marcel Ardand, Nouvelle Revue Française, 15e année, No. 173 (February 1, 1928), pp. 250-52.

Review of L'Imposture, by Georges Bernanos, Nouvelle Revue Française, $15^{\mathrm{e}}$ année, No. 174 (March 1, 1928), pp. 406-8.

"Contes, historiettes et fabliaux," review of Dialogue d'un prêtre et d'un moribond, by Le Marquis de Sade, Nouvelle Revue Française, 15e année, No. 177 (June 1, 1928), pp. 853-55.

Review of L'Enfant et l'écuyère, by Franz Hellens, Nouvelle Revue Française, $15^{\text {e }}$ année, No. 179 (August 1, 1928), pp. 291-92. 


\section{ANDRE MALRAUX: TRAGIC HUMANIST 251}

Review of Battling le ténébreux, by Alexandre Vialatte, Nouvelle Revue Française, 16e année, No. 183 (December 1, 1928), pp. 869-70.

Review of Journal de voyage d'un philosophe, by Hermann Keyserding, Nouvelle Revue Française, 16 année, No. 189 (June 1, 1929), pp. 884-86.

"Les Conquérants, fragment inédit," Bifur, No. 4 (December 31, 1929), pp. 5-15.

"Exposition Gothico-Bouddhique-Exposition Gréco-Bouddhique," Nouvelle Revue Française, February, 1931, pp. 298-300.

"Réponse à Léon Trotsky," Nouvelle Revue Française, 19e année, No. 211 (April 1, 1931), pp. 501-7.

Preface to L'Amant de Lady Chatterley, by D. H. Lawrence (Paris: Gallimard, 1932).

"Jeune Chine," Nouvelle Revue Française, $20^{e}$ année, No. 220 (January 1, 1932), pp. 5-7.

Review of Documents secrets, by Franz Heldens, Nouvelle Revue Française, $20^{\mathrm{e}}$ annẻe, No. 224 (April 1, 1932), pp. 915-16.

Review of En Marge d'Hymenée, by Louis Guilloux, Europe, June 15, 1932, pp. 304-7.

"Exposition Fautrier," Nouvelle Revue Française, 21e année, No. 233 (February 1, 1933), pp. 345-46.

"A l'hôtel des sensations inédites," Marianne, December 13, 1933.

Preface to Sanctuaire, by William Fadlkner (Paris: Gallimard, 1933). "S.O.S.," Marianne, October 11, 1933, p. 3.

"Trotzky," Marianne, April 25, 1934, p. 3.

"A la Découverte de la Capitale Mystérieuse de la Reine de Saba," L'Intrasigeant, May 3-13, 1934.

Review of Les Traqués, by M. Matveev, Nouvelle Revue Française $22^{\mathbf{e}}$ année, No. 249 (June 1, 1934), pp. 1014-16. 
"L'Art est une conquête," Commune, Nos. 13-14 (September-October, 1934), pp. 68-71.

"Attitude de l'artiste," Commune, No. 15 (November, 1934), pp. 166-75.

"L'Euvre d'art," Commune, No. 23 (July, 1935), pp. 264-66.

Review of Sans Reprendre Haleine, by Ilya Ehrenboura, Nouvelle Revue Française, November, 1935, pp. 770-72.

Review of Les Nouvelles Nourritures, by ANDRÉ GIDE, Nouvelle Revue Française, December, 1935, pp. 935-37.

"Réponse aux 64,' Commune, No. 27 (December, 1935), pp. 410-16.

Preface to Indochine S.O.S., by ANDRÉE Violdis (Paris: Gallimard, 1935).

"Sur l'Héritage Culturel," Commune, September, 1936, pp. 1-9.

Preface to Messages personnels, by Bergeret and Grégorre (Bordeaux: Bière, 1945).

"Espoir, Film," La Nef, June, 1945, pp. 7-18.

"N'était-ce donc que cela," Saisons, 1946.

"L'Homme et la culture artistique," Les Conférences de l'Unesco (Paris: Fontaine, 1947), pp. 75-89.

"Culture," Liberté de l'esprit, No. 1 (February, 1949), pp. 1-2.

"N'était-ce done que cela," Liberté de l'esprit, Nos. 3, 4, and 5 (April, May, and June, 1949), pp. 49-51, 86-87, 117-18 (Le Démon de l'absolu). (Reprint of article from Saisons.)

"Résurrections," Liberté de l'esprit, No. 8 (January, 1950), pp. 1-2.

"Un humanisme universel," Liberté de l'esprit, Nos. 11-12 (June-July, 1950), p. 103.

"Dix Ans Après," Liberté de l'esprit, June-July, 1950, p. 103.

"De l'artiste," Liberté de l'esprit, 3e année, No. 19 (March, 1951), pp. 65-67. 


\section{ANDRE MALRAUX: TRAGIC HUMANIST 253}

"De l'art et des masses," Liberté de l'esprit, 3e année, No. 22 (June, 1951), pp. $177-80$.

“André Malraux Nous Dit," Arts, November 30, 1951, pp. 1-10.

"Le Gaullisme sans De Gaulle et les Républicains sans République," Carrefour, No. 3 (January, 1956), p. 1.

Preface to Qu'une larme dans l'océan, by Manès Sperber (Paris: Calmann-Lévy, 1952)

"L'Etat n'est pas fait pour diriger l'art mais pour le servir," Carrefour, March 26, 1952, pp. 1-5.

"Occidentaux, quelles valeurs défendez-vous," Carrefour, June 4, 1952, pp. 1-6.

Introduction to Tout Vermeer de Delft (Paris: Gallimard, 1952).

"Fidelité," Introduction to Van Gogh et les peintres d'Auvers chez le Docteur Gachet (Paris: L'Amour de l'art, 1952).

“André Malraux achève une véritable enquête policière," Arts et Spectacles, September $19,1952$.

Introduction to Tout l'oeuvre peint de Leonard de Vinci (Paris: Gallimard, 1952).

Letter-preface to Essai de stratégie occidentale, by GeneraL P. E. Jagquot (Paris: Gallimard, 1953)

"Premier entretien avec André Malraux," L'Express, December 24, 1954, pp. 10-11.

"La Nouvelle Gauche Peut Réussir," L'Express (January, 1955), pp. 3-5.

"Sur Saint-Just," Nouvelle Revue Française, 3e année, No. 25 (January 1, 1955), pp. 1-21.

Preface to Le Sang noir, by Louis Guilloux (Paris: Club du Meilleur Livre, 1955). (Written in 1935.)

Preface to Israël, by IzIs (Lausanne: Clairefontaine, 1955).

Preface to Manuscrits à peintures du XIII $I^{\mathrm{e}}$ au XVI siècles (Paris: Bibliothèque Nationale, 1955). 
"L'Homme et le fantôme," Daglig Nyhiter, 1955. (I have not seen this item printed, but have seen a typescript furnished by Malraux.)

"Dialogue entre Montherlant et Malraux autour de Racine," L'Express, February 26, 1956, pp. 12-14.

"André Malraux parle de Rembrandt," L'Express, April 20, 1956, pp. 18-19.

Preface to Sumer, by André Parrot. (L'Univers des formes, Vol. I.) Paris: Gallimard, 1960.

\section{Worts on Malraux}

aguanno, Gaspard D'. Les Héros sombres et désespérés d'André Malraux. Trapani: La Sorgente, 1955.

Blumenthal, Gerda. André Malraux and the Conquest of Dread. Baltimore: Johns Hopkins University Press, 1960.

Boisdefrre, Pierre de. André Malraux. (Classiques du XXe siecle. Vol. I.) Paris: Editions Universitaires, 1952.

Delhomme, Jeanne. Temps et Destin. Paris: Gallimard, 1955.

Esprit. October, 1948. The largest part of this issue is devoted to an "Interrogation à Malraux."

Frohock, Wilbur Merrill. André Malraux and the Tragic Imagination. Stanford, Calif.: Stanford University Press, 1952.

Gannon, Edward, S.J. The Honor of Being a Man. Chicago: Loyola University Press, 1957

Hartman, Geoffrey. André Malraux. New York: Hillary House, 1960. 


\section{ANDRE MALRAUX: TRAGIC HUMANIST 255}

Malraux, Clara. Portrait de Griselédis. Paris: Colbert, 1945. Par de plus longs chemins. Paris: Stock, 1953. (These fictional works by Malraux's former wife are drawn largely from her life with him.)

Matriac, Claude. Malraux ou le mal du héros. Paris: Grasset, 1946.

Moray, Aloys. A la rencontre d'André Malraux. Brussels: La Sixaine, 1947.

Patry, André. Visages d'André Malraux. Montreal: Hexagon, 1956.

Picon, GaËran. André Malraux. ("Collection les Essais.") Paris: Gallimard, 1945.

- Malraux par lui-même. ("Ecrivains de toujours.") Paris: Edition du Seuil, 1953.

Savane, Marcel. André Malraux. ("Collection Triptyque-Littérature.") Paris: Richard-Masse, 1946.

Yale French Studies, Winter, 1957. (The entire issue is devoted to a study of Malraux.) 









(continued from front flap)

an image of him or to visualize a form for human culture, and traditional humanism passes from the picture.

For Malraux, however, man has something that is greater than a preconceived image of himself : consciousness or awareness. To replace the images of man that have been destroyed or invalidated, Malraux calls for the will to grasp the greatest possible consciousness of what it is to be a man, coupled with the will to absolutely free discovery. Combining these values, Malraux suggests, produces a culture that is a human adventure, an adventure in freedom. Humanism is still possible, but it is a tragic humanism-humanism, because man knows his will and his starting point; tragic, because he can never know where he is going. Man can lead a dignified and fruitful existence given the will to struggle endlessly with the unknown.

Charles D. Blend is chairman of the Department of Romance Languages, Woman's College, University of North Carolina. 
